\title{
A MANDATORY VIEW OF FEDERAL COURT JURISDIGTION: A GUIDED QUEST FOR THE ORIGINAL UNDERSTANDING OF ARTICLE III
}

\author{
Robert N. Clinton†
}

\section{INTRODUCTION}

In a dissenting opinion, Justice Frankfurter once wrote:

No provisions of the Constitution, barring only those that draw on arithmetic, ... are more explicit and specific than those pertaining to courts established under Article III. "The judicial power" which is "vested" in these tribunals and the safeguards under which their judges function are enumerated with particularity. Their tenure and compensation, the controversies which may be brought before them, and the distribution of original and appellate jurisdiction among these tribunals are defined and circumscribed, not left at large by vague and elastic phrasing. The precision which characterizes these portions of Article III is in striking contrast to the imprecision of so many other provisions of the Constitution dealing with other very vital aspects of government. ${ }^{1}$

Nothing could be further from the truth. Despite Frankfurter's confident assertions, the meaning of article III is not only far from evident, but has been made positively murky by judicial and scholarly misinterpretation, as this Article will attempt to show.

As adopted by the Constitutional Convention in 1787, article III

\section{- Copyright 1983 by Robert N. Clinton.}

† Professor of Law, University of Iowa. B.A. 1968, University of Michigan; J.D. 1971, University of Chicago. The author gratefully acknowledges the assistance of Richard A. Matasar, his esteemed colleague, who served as a foil for this writer's ideas and who reviewed and made extensive comments on various drafts of this Article, and to Ronald J. Allen of the Northwestern University Law School, and Carole GoldbergAmbrose of the UCLA Law School, who also offered their views. The author also wishes to thank Margery A. Huston for the valuable and tireless research assistance that she provided on the Article, and Eleanor E. Lynn for her ideas and support. This Article was generously supported by a research grant from the University of Iowa Law School Foundation. The views expressed in this Article, however, are solely those of the author.

${ }_{1}$ National Mut. Ins. Co. v. Tidewater Transfer Co., 337 U.S. 582, 646 (1949) (Frankfurter, J., dissenting); see also Northern Pipeline Constr. Co. v. Marathon Pipe Line Co., 458 U.S. 50, 92 (1982) (White, J., dissenting) ("Article III, § 1, of the Constitution is straightforward and uncomplicated on its face"). 
of the United States Constitution provides in relevant part:

SECTION 1. The judicial Power of the United States, shall be vested in one supreme Court, and in such inferior Courts as the Congress may from time to time ordain and establish. The Judges, both of the supreme and inferior Courts, shall hold their Offices during good Behaviour, and shall, at stated Times, receive for their Services, a Compensation, which shall not be diminished during their Continuance in Office.

SEGTION 2. The Judicial Power shall extend to all Cases, in Law and Equity, arising under this Constitution, the Laws of the United States, and Treaties made, or which shall be made, under their Authority; - to all Cases affecting Ambassadors, other public Ministers and Consuls;-to all Cases of admiralty and maritime Jurisdiction;-to Controversies to which the United States shall be a Party;-to Controversies between two or more States;-between a State and Citizens of another State;-between Citizens of different States;-between Citizens of the same State claiming Lands under Grants of different States, and between a State, or the Citizens thereof, and foreign States, Citizens or Subjects.

In all Cases affecting Ambassadors, other public Ministers and Consuls, and those in which a State shall be Party, the supreme Court shall have original Jurisdiction. In all the other Cases before mentioned, the supreme Court shall have appellate Jurisdiction, both as to Law and Fact, with such Exceptions, and under such Regulations as the Congress shall make.

The trial of all Crimes, except in Cases of Impeachment, shall be by Jury; and such Trial shall be held in the State where the said Grimes shall have been committed; but when not committed within any State, the Trial shall be at such Place or Places as the Congress may by Law have directed. ${ }^{2}$

The meaning of the judicial article has perplexed practitioners, judges, and scholars since its inception and has spawned a significant debate concerning the scope of congressional control over federal court jurisdiction. $^{3}$ The debate has been fueled by recurrent proposals in

2 U.S. Const. art. III, $\S \S 1-2$.

3 See R. Berger, Congress v. The Supreme Court 285-96 (1969); W. Crosskey, Politics ANd The Constrturton 616-20 (1953); J. Goebel, History 
Congress to curtail portions of the jurisdiction of the Supreme Court of

of the Supreme Court of the United States: Antecedents and Beginnings To 1801, 196-412 (1971); M. Redish, Federal JuRISDiction: TENSIONS IN THE Allocation of Judicial Power 7-34 (1980); C. Rice, Congress and Supreme CourT JuRISDICTION (1980); Abraham, Limiting Federal Court Jurisdiction: $A$ "SelfInflicted Wound?", 65 JudicATURE 179 (1981); Auerbach, The Unconstitutionality of Congressional Proposals to Limit the Jurisdiction of Federal Courts, 47 MO. L. REv. 47 (1982); Bator, Congressional Power over the Jurisdiction of the Federal Courts, 27 VILL. L. Rev. 1030 (1982); Baucus \& Kay, The Court Stripping Bills: Their Impact on the Constitution, the Courts, and Congress, 27 VILL. L. REv. 988 (1982); Berger, Insulation of Judicial Usurpation: A Comment on Lawrence Sager's "Court-Stripping"' Polemic, 44 Ohro ST. L.J. 611 (1983); Bice, An Essay Review of Congress v. The Supreme Court, 44 S. GaL. L. Rev. 499 (1971); Brant, Appellate Jurisdiction: Congressional Abuse of the Exceptions Clause, 53 OR. L. REv. 3 (1973); Eisenberg, Congressional Authority to Restrict Lower Federal Court Jurisdiction, 83 YALE L.J. 498 (1974); Forkosch, The Exceptions and Regulations Clause of Article III and a Person's Constitutional Rights: Can the Latter be Limited by Congressional Power Under the Former?, 72 W. VA. L. REv. 238 (1970); Frank, Historical Bases of the Federal Judicial System, 13 LAw \& ConTEMP. PROBS. 3 (1948); Hart, The Power of Congress to Limit the Jurisdiction of Federal Courts: An Exercise in Dialetic, 66 HaRv. L. Rev. 1362 (1953), updated and reprinted in B. BATOR, P. Mishkin, D. Shapiro \& $\mathrm{H}$. Wechsler, Hart and Wechsler's The Federal Courts and THE FEDERAL System 330 (2d ed. 1973) [hereinafter cited as HaRT \& WEchsLER]; Kay, Limiting Federal Court Jurisdiction: The Unforeseen Impact on Courts and Congress, 65 Judicature 185 (1981); Levy, Congressional Power Over the Appellate Jurisdiction of the Supreme Court: A Reappraisal, 22 N.Y. INTRA. L. REv. 178 (1967); McClellan, Congressional Retraction of Federal Court Jurisdiction to Protect the Reserved Powers of the States: The Helms Prayer Bill and a Return to First Principles, 27 Vill. L. REv. 1019 (1982); Merry, Scope of the Supreme Court's Appellate Jurisdiction: Historical Basis, 47 MINN. L. REv. 53 (1962); Meserve, Limiting Jurisdiction and Remedies of Federal Courts, 68 A.B.A. J. 159 (1982); Ratner, Majoritarian Constraints on Judicial Review: Congressional Control of Supreme Court Jurisdiction, 27 Vill. L. REv. 929 (1982); Ratner, Congressional Power Over the Appellate Jurisdiction of the Supreme Court, 109 U. PA. L. REv. 157 (1960) [hereinafter cited as Ratner, Power]; Redish, Congressional Power to Regulate Supreme Court Appellate Jurisdiction Under The Exceptions Clause: An Internal and External Examination, 27 Vinl. L. REv. 900 (1982); Redish, Constitutional Limitations on Congressional Power to Control Federal Jurisdiction: A Reaction to Professor Sager, 77 Nw. U.L. REv. 143 (1982); Redish \& Woods, Congressional Power to Control the Jurisdiction of Lower Federal Courts: A Critical Review and a New Synthesis, 124 U. PA. L. Rev. 45 (1975); Rice, Congress and the Supreme Court's Jurisdiction, 27 VuL. L. REv. 959 (1982); Rice, Limiting Federal Court Jurisdiction: The Constitutional Basis for the Proposals in Congress Today, 65 Judicature 190 (1981); Rotunda, Congressional Power to Restrict the Jurisdiction of the Lower Federal Courts and the Problem of School Busing, 64 GEo. L.J. 839 (1976); Sager, The Supreme Court, 1980 Tern-Foreword: Constitutional Limitations on Congress' Authority to Regulate the Jurisdiction of the Federal Courts, 95 HARv. L. REv. 17 (1981); Sloviter, Introduction: Legislative Proposals to Restrict the Jurisdiction of the Federal Courts: Are They Wise? Are They Constitutional?, 27 VILL. L. REv. 895 (1982); Strong, Rx for a Nagging Constitutional Headache, 8 SAN Diego L. Rev. 246 (1971); Taylor, Limiting Federal Court Jurisdiction: The Unconstitutionality of Current Legislative Proposals, 65 JUDICATURE 199 (1981); Tribe, Jurisdictional Gerrymandering: Zoning Disfavored Rights Out of the Federal Courts, 16 HARv C.R.-C.L. L. REv. 129 (1981); Van Alstyne, A Critical Guide to Ex Parte McCardle, 15 ARIz. L. REv. 229 (1973); Wechsler, The Courts and the Constitution, 65 Conum. L. Rev. 1001 (1965); Young, Congressional Regulation of Federal Courts' Jurisdiction and Processes: United States v. 


\section{the United States or the inferior federal courts. ${ }^{4}$}

Such proposals are, of course, not a recent phenomenon, having been advanced frequently in Congress over the last fifty years to alter or avoid politically controversial decisions. ${ }^{5}$ Some would curtail the ju-

Klein Revisited, 1981 WIs. L. REv. 1189 (1981); Note, Congressional Power Over State and Federal Court Jurisdiction: The Hill-Burton and Trans-Alaska Pipeline Examples, 49 N.Y.U. L. REV. 131 (1974).

- Some of the more recent examples of such proposals include: H.R. 72, H.R. 326, H.R. 408, H.R. 989, H.R. 1335, H.R. 2347, H.R. 4756, H. Con. Res. 97, S. 481, S. 1742, 97th Cong., 1st Sess. (1981) (removing federal court jurisdiction over cases attacking "voluntary" prayer in the public schools); H.R. 340, H.R. 761, H.R. 869, H.R. 1079, H.R. 1180, H.R. 2047, H.R. 3332, H.R. 5200, S. 528, S. 1005, S. 1147, S. 1647 , S. 1743, S. 1760, 97th Cong., 1st Sess. (1981) (restricting the jurisdiction of the federal courts to issue certain mandatory school busing orders as remedies in school desegregation cases); H.R. 73, H.R. 867, H.R. 900, H.R. 3225, S. 158, S. 583, 97th Cong., 1st Sess. (1981) (restricting the jurisdiction of the federal courts over cases involving abortion laws); H.R. 2365, 97th Cong., 1st Sess. (1981) (curtailing federal court jurisdiction over cases challenging the validity of any federal law providing for male-only registration for, or induction into, the military service).

s See, e.g., S. 917, 90th Cong., 2d Sess. (1968) (proposal to remove the jurisdiction of the federal courts to review any state criminal conviction based on a confession of the accused that was admitted into evidence "as voluntarily made"); S. 4058, 90th Cong., 2d Sess. (1968) (removing the jurisdiction of the federal courts to review or set aside any finding by a state court of obscenity in a criminal prosecution); H.R. 1584, H.R. 1586, H.R. 2400, H.R. 712, H.R. 6621, 89th Cong., 1st Sess. (1965) and H.R. 11,926, 88th Cong., 2d Sess. (1964) (removing the appellate jurisdiction of the Supreme Court over cases challenging the apportionment of any state legislature); S. 3069, 88th Cong., $2 d$ Sess. (1964) (mandating a stay of any such apportionment case brought in a federal court until the end of the second regular session of the state legislature); S. 3386, 85th Cong., 2d Sess. (1958) (removing federal court jurisdiction over cases involving state bar admissions); S. 2646, H.R. 9207, 85th Cong., 1st Sess. (1957) (removing Supreme Court appellate jurisdiction over state subversive legislation, contempt of Congress, federal employees security program, and state bar admission cases); H.R. 11,795 and H.R. 8906, 84th Cong., 2d Sess. (1956) (various responses to the school desegregation decision in Brown v. Board of Educ., 347 U.S. 483 (1954)); H.R. 10,128, 74th Cong., 2d Sess. (1935) (divesting all state and federal courts other than the Supreme Court of jurisdiction over cases as to the constitutionality of any act of Congress enacted under congressional powers to provide for the general welfare, to tax, to regulate interstate commerce, to issue money, or which affects substantive due process rights); see also, H.R. 10,839, 74th Cong., 2d Sess. (1935) (removing the power of inferior federal courts to declare any statute of the United States unconstitutional) and H.R. 2265, H.R. 3895, H.R. 5172, H.R. 5485, H.R. 7154, H.J. Res. 276, H.J. Res. 293, H.J. Res. 307, H.J. Res. 366, H.J. Res. 372, H.J. Res. 496, S. 1098, S. 1276, S. 1890, S.J. Res. 98, S.J. Res. 100, 75th Cong., 1st Sess. (1935) (requiring the vote of a specified extraordinary majority of the Supreme Court Justices to declare an act of Congress invalid); H.J. Res. 372 and H.J. Res. 496, 75th Cong., 1st Sess. (1935) (requiring a two-thirds vote of the justices of the Supreme Court to declare invalid any state or federal act). See generally 3 C. Warren, The Supreme Court in UnIted States History 465-66 (1922); Fite \& Rubinstein, Curbing the Supreme Court-State Experiences and Federal Proposals, 35 Mich. L. Rev. 762 (1937); Martig, Congress and the Appellate Jurisdiction of the Supreme Court, 34 MICH. L. REv. 650 (1936); Nagel, Court-Curbing Periods in American History, 18 VAND. L. REv. 925 (1965); Richter, A Legislative Curb on the Judiciary, 21 J. PoL. Econ. 281 (1913); Stumpf, Congressional Response to Supreme Court Rulings: The Interaction of Law and Polit- 
risdiction of the inferior federal courts, leaving that of the Supreme Court intact. ${ }^{6}$ Other jurisdictional proposals would remove the jurisdiction of both the inferior federal courts and the Supreme Court, leaving only the state courts to resolve the federal questions that such cases pose. ${ }^{7}$ There also have been attempts to eliminate only the appellate jurisdiction of the Supreme Court over a class of cases, leaving the jurisdiction of the inferior federal courts intact, the most notable example being Ex parte McCardle. ${ }^{8}$ Other proposals would only curtail the remedies that an inferior federal court may issue in a case otherwise within the court's jurisdiction. ${ }^{\circ}$ Other bills have been introduced in response to politically controversial cases with the intent to alter the structure or procedures of the federal courts. ${ }^{10}$

ics, 14 J. PUB. L. 377 (1965).

- See, e.g, S. 158, H.R. 900, 97th Cong., 1st Sess. (1981) (the so-called "Human Life Statute" proposed by Senator Helms and Congressman Hyde to curtail the jurisdiction of inferior federal courts to issue any injunction or declaratory judgment in cases involving state or municipal laws or ordinances regulating or restricting the availability of abortions).

7 See, e.g., S. 1742, 9th Cong., 1st Sess. (1981) (curtailing all federal court jurisdiction over cases attacking the practice of voluntary prayer in the public schools).

74 U.S. (7 Wall.) 506, 514 (1869) (sustaining the retroactive repeal by Congress of Supreme Court jurisdiction to entertain appeals of habeas corpus applications from the lower federal courts on writ of error).

The two most important and enigmatic cases on the question of congressional power over the jurisdiction of the federal courts are Ex parte McCardle and United States v. Klein, 80 U.S. (13 Wall.) 128 (1871) (invalidating legislation directing the Court of Claims and the Supreme Court to summarily dismiss war claims cases brought by individuals who had accepted a pardon and providing that the acceptance of the pardon should be treated as conclusive evidence of disloyalty during the Civil War). In addition to the statutes at issue in these cases, Congress has enacted certain other statutes that have received less attention as jurisdictional curtailment statutes. See, e.g., 28 U.S.C. § 1341 (1976) (Anti-Tax Injunction Act prohibiting most federal court injunctions against the assessment, levy, or collection of any tax under state law); 28 U.S.C. $\$ 1342$ (1976) (Johnson Act prohibiting federal court interference with state rate orders for public utilities); 28 U.S.C. \$ 2283 (1976) (Anti-Injunction Act prohibiting federal courts from restraining pending state proceedings except in certain circumstances). The Anti-Tax Injunction Act and the Johnson Act, indeed, were enacted in the 1930's in response to decisions of the federal courts hostile to the interests that the statutes sought to protect.

- E.g., S. 528, 97th Cong. 1st Sess. (1981) (the so-called "Neighborhood School Act" designed to restrict the power of the federal courts to issue mandatory school busing orders); see Lauf v. E.G. Shinner \& Co., 303 U.S. 323 (1938) (sustaining provisions of the Norris-LaGuardia Act of 1932 depriving federal courts of "jurisdiction" to issue injunctions in certain labor disputes); Taylor v. St. Vincent's Hospital, 369 F. Supp. 948 (D. Mont. 1973) (sustaining section 401(b) of the Health Programs Extension Act of 1973 providing that the receipt by a private hospital of federal funding does not authorize any court or public official to require the hospital to perform abortions or sterilizations if the hospital prohibits them on the grounds of religious belief or moral conviction), affd, 523 F.2d 75 (1975).

10 The most famous of such proposals was President Franklin D. Roosevelt's court-packing plan. See generally G. GUNTHER, CASES AND Materials on CoNSTITUtIONAL LAW 150-52 (10th ed. 1980); Leuchtenburg, The Origins of Franklin D. 
This Article will examine the history surrounding the drafting and ratification of the judicial article in order to discern any original intention of the framers ${ }^{11}$ that might be relevant to current debates over the

Roosez'elt's "Court-Packing" Plan, 1966 SuP. CT. Rev. 347. Proposals were also submitted in Congress during the feud between the Court and the New Deal Democrats to either oust the Court of jurisdiction to declare federal laws unconstitutional or to raise the number of Justices whose concurrence was necessary to invalidate a federal or state act. More recently, such sweeping curtailments of federal court jurisdiction have also been introduced in Congress, albeit without receiving any serious consideration. See e.g., H.R. 5183, 97th Cong., 1st Sess. (1981) (providing for congressional disapproval of federal court decisions declaring any federal or state law unconstitutional); H.R. 114,97 th Cong., 1st Sess. (1981) (depriving the federal courts of jurisdiction to modify, directly or indirectly, any order of a court of any state that was subject to review by the state's highest court); H.R. 5181, 97th Cong., 1st Sess. (1981) (curtailing the jurisdiction of the federal courts to issue orders requiring the expenditure of federal or state funds without legislative authorization); see also H.J. Res. 384, 90th Cong., 1st Sess. (1967) (providing that the Supreme Court would exercise original and exclusive jurisdiction over all cases in which the constitutionality of a federal or state law is drawn in question and requiring unanimous concurrence of the Justices to invalidate an act). Obviously, many of these sweeping proposals are patently inconsistent with the constitutional plan established in article III. Nevertheless, they indicate the breadth of legislative power that some members of Congress have on occasion believed may be exercised over the jurisdiction of the federal courts.

11 As used in this Article, "original intention of the framers" or "original understanding of the framers" refers to constitutional meaning derived from objective data, such as the available published debates, votes, and writings of the members of the Philadelphia Convention and the state ratification conventions. In ascertaining such meaning, the objective record must be read in light of the linquistic conventions and jurisprudential assumptions and concerns of the time. Reference to an objective original understanding, however, should not be taken to mean that the process of ascertaining meaning is completely devoid of subjective elements. The process of ascertaining the meaning of a written text ultimately involves a search for the collective subjective understanding held by the drafters of the document. Indeed, there is a school of historical interpretation that requires some analysis of the subjective elements of understanding and intent. See, e.g., J. Pocock, Politics, Language and TIME: Essays on PolitICAL Thought AND HIstory (1971); Pocock, Political Thought and Political Action: A Symposium on Quentin Skinner, 2 POL. THEORY 251 (1974); Skinner, Meaning and Understanding in the History of Ideas, 8 Hist. \& THEORY 3 (1969).

References in this Article to the objective original understanding imply only that the data upon which the argument will be based are made up of objective primary historical documents and accounts, rather than some psychobiographic resort to unarticulated, subjective premises that may have motivated the framers. While the non-legal historian can tolerate the ambiguities and uncertainties engendered by such subjective inquiries, the lawyer needs more definitive guidance from history and is less tolerant of the ambiguities introduced by more wide-ranging psychological inquiries. This is not to say, however, that the lawyer's search for original understanding should attempt to create definitive understandings where none existed. The legal historian always must be methodologically circumspect, cautiously asking whether the data yield or suggest a definitive original understanding or whether the conclusion offered merely constitutes a conclusion that later generations have retroactively imposed on malleable and inconclusive historical materials.

The interpretive approach presented here seeks to derive meaning from the conventional data generally used by lawyers and courts in searching for the original meaning of statutes or constitutional documents. This approach places heavy reliance on the views that drafters were willing to express publicly, at least within the halls of the 


\section{source and scope of congressional power over the jurisdiction of the}

Philadelphia Convention. The methodology deliberately gives little weight to more speculative, unarticulated motivations. The approach also does not treat all drafters as equals. It places primary reliance on the actions and statements of most vocal and active proponents or drafters of the document, on the assumption that the views would have been openly challenged or corrected if out of step with the remainder of the supporters of the document. While the author recognizes that this methodology is open to attack by those favoring a more subjective analysis of original understanding, he adheres here to the conventional approach out of respect for legal and historical traditions and because he views any departure from this approach as introducing highly speculative and imponderable features into the interpretive search for meaning.

In searching for such original understanding, the legal historian must also always remember that she is looking at the primary historical data through lenses that have been clouded by contemporary issues and by the perspective of intervening legal, social, and political history. Thus, in this sense the legal historian's quest for original understanding may never truly replicate the framers' understanding. See Sandalow, Constitutional Interpretation, 79 Mich. L. REv. 1033, 1064-66 (1981). Serious doubt has been cast on the existence of pure objective history. See H. Gadamer, TruTH and Method (1975); P. Winch, The Idea of a Social Sctence and ITS Relation to Philosophy (1958); Taylor, Interpretation and the Sciences of Man, 25 REv. METAPHYSics 3 (1971). Contra E. Hirsch, Validity IN INTERPRETATION 245-64 (1967). Nevertheless, the legal historian can fortify herself against potential misinterpretation by attempting to assure, as suggested above, that the perspective adopted in reviewing the data involves the linquistic and jurisprudential conventions of the drafters' era, not those of the historian's training or time.

While pristine historical certainty may be unattainable, these impediments to historical exploration should not prevent embarkation on the journey nor taint the knowledge of the historical terrain that the exploration yields. Just as Heisenberg's uncertainty principle tells the scientist that the very process of scientific measurement of the natural world changes that world and colors the data derived from the exploration, the problems of historical interpretation are affected by the legal perceptions and predilections of the legal historian as well as those of the contemporary society in which the historian was trained and operates. Nevertheless, just as Heisenberg's observation has merely counseled caution rather than causing the process of scientific inquiry to grind to a halt, the difficulties in ascertaining original understanding should cause lawyers, courts, and historians to be cautious and demanding in their inquiries, not to abandon the historical quest. Contra Sandalow, supra, at 1060-71 (comments of Dean Sandalow attacking the validity of any search for original constitutional understanding that would limit the interpretive discretion of the courts).

While there are important differences between the process of statutory construction and constitutional adjudication, there are remarkable similarities as well. In both situations there is the same problem of ascertaining a single meaning or, at least, a limited range of meaning, from a multi-member body, not all members of which may have spoken on or agreed to the views offered by the most active participants in the debates.

With all its analytical problems and pitfalls, attempting to ascertain an objective original understanding of a statute is necessary to limit judicial discretion in order to support the views of democratically elected legislative representatives. See generally Clinton, Judges Must Make Law: A Realistic Appraisal of the Judicial Function in a Democratic Society, 67 Iowa L. REv. 711, 717-21 (1982). While majoritarian concerns should be more limited in the sphere of constitutional adjudication, see id. at 721-25, unbridled judicial discretion similarly must be eschewed. Where clearly ascertainable, original understandings of constitutional clauses should be followed to help preserve the proper allocation of roles within constitutional government, just as the legislative intent of the drafters of a statute should be followed to help assure representative democratic government. 
federal courts. Hopefully, this examination will bring truth to Justice Frankfurter's vision of simplicity, albeit a truth of which the Justice might not have approved.

While some of the literature on congressional power over federal jurisdiction addresses the history of the judicial article summarily, the bulk of the writing in this field has been devoted to more current doctrinal and policy considerations. This Article departs from that tradition by focusing attention exclusively on the original intention of the drafters and ratifiers of article III, eschewing for the present the modern doctrinal implications of that inquiry.

Thus, this Article does not directly address the constitutionality of modern proposals to curtail the jurisdiction of the federal judiciary. The findings of this Article, however, may significantly influence that debate. The constitutionality of the proposals to curtail jurisdiction turns on complex questions involving the interpretation of prior precedent and the view one takes of the appropriate role of constitutional text and original intention in the resolution of constitutional questions. For the interpretivist, ${ }^{12}$ this Article may therefore provide insights and

Judicial discretion, of course, must exist in the process of constitutional adjudication, particularly where the original intent of the framers is obscure or non-ascertainable or where the constitutional question presented to the court was not foreseen by the drafters of the Constitution. Thus, this Article is devoted to ascertaining whether there is any clear objective evidence of an original understanding regarding congressional power over the scope of federal court jurisdiction. If that question is answered in the negative, then the courts' interpretive discretion would not be limited by any historical original understanding of article III. On the other hand, if such a clear original understanding can be demonstrated, as argued in this Article, the discretion of the courts to interpret article III is thereby limited. Interpretation of a constitutional clause contrary to its originally intended meaning simply cannot readily be reconciled with any theory that supports a written constitution.

${ }_{12}$ The interpretivist school tends to view the process of constitutional decisionmaking exclusively as a search for the original intent or understanding underlying the texi of the Constitution; non-interpretivist thinkers tend to look to a much wider range of sources for guidance in such decisionmaking. For a small sample of the debate between the interpretivist and non-interpretivist schools of thought in constitutional law, compare R. BERGER, GOVERNMENT BY JUDICIARY 283-99, 363-72 (1977), and Berger, Paul Brest's Brief for an Imperial Judiciary, 40 MD. L. REv. 1 (1981), with Bice, supra note 3, and Brest, The Misconceived Quest for the Original Understanding, 60 B.U.L. Rev. 204 (1980). See generally Alexander, Modern Equal Protection Theories: A Metatheoretical Taxonomy and Critique, 42 Oно ST. L.J. 3 (1981). For a recent rejection of the relevance of original understanding and interpretivist thinking to interpretation of article III, see Justice White's dissent in Northern Pipeline Constr. Co. v. Marathon Pipe Line Co., 458 U.S. 50 (1982):

If this simple reading [of article III] were correct and we were free to disregard 150 years of history, this would be an easy case. . . .

[The] question is what limits Article III places on Congress' ability to create adjudicative institutions designed to carry out federal policy established pursuant to the substantive authority given Congress elsewhere in the Constitution. Whether fortunate or unfortunate, at this point in the 
ammunition with which to launch an attack on the constitutionality of jurisdictional curtailment proposals. It may also pose some difficult questions regarding proposals to abolish diversity jurisdiction. ${ }^{13}$ For the noninterpretivist, this excursion into legal history may pose troublesome, although non-dispositive, questions regarding the appropriate scope of congressional power over federal court jurisdiction. Furthermore, for scholars of any ilk, the conclusions of this piece may stimulate further inquiry into the legitimate scope of departure from the originally intended meanings of constitutional provisions. In this Article, the author proposes, however, only to present and interpret the historical data surrounding the adoption of article III, leaving to later debate the equally important issue of the current significance of that information.

The debates over congressional power to curtail federal court jurisdiction generally have centered around the interpretation of particular clauses in article III taken in isolation. Thus, disputes over the existence and scope of congressional power to curtail the appellate jurisdiction of the United States Supreme Court have focused on the interpretation of the exceptions and regulations clause ${ }^{14}$ of section 2 of article III. Analyses of the power of Congress to curtail the jurisdiction of the inferior federal courts have focused almost entirely on the language in section 1 of article III, authorizing Congress to vest article III jurisdiction in such inferior courts as it "may from time to time ordain and establish"16 and on the corollary congressional power contained in section 8 of article I "[t]o constitute Tribunals inferior to the supreme Court."16 Little attention has been paid to the light that the overall structure of the article sheds on the meaning of its constituent clauses or to the bearing that the debates in the Constitutional Convention and the ratification process have on ambiguities in the language of article III. This Article is devoted to precisely such an inquiry.

The conclusion of this inquiry is that the framers, by providing that "[t]he judicial Power of the United States, shall be vested in one supreme Court and in such inferior Courts as the Congress may from time to time ordain and establish,"17 intended to mandate that Congress

history of constitutional law that question can no longer be answered by looking only to the constitutional text. This Court's cases construing that text must also be considered.

Id. at 93-94.

${ }^{18}$ See, e.g., H.R. 6691, 97th Cong., 2d Sess. (1982); H.R. 6816, 97th Cong., 2d Sess. (1982).

14 U.S. Const. art. III, § 2.

15 Id. art. III, § 1.

16 Id. art. I, \& 8, cl. 9.

17 Id. art. III, $\S 1$ (emphasis added). 
allocate to the federal judiciary as a whole each and every type of case or controversy defined as part of the judicial power of the United States by section 2, clause 1 of article III, excluding, possibly, only those cases that Congress deemed to be so trivial that they would pose an unnecessary burden on both the federal judiciary and on the parties forced to litigate in federal court. ${ }^{18}$ The intent of the framers was succinctly summarized by Alexander Hamilton in The Federalist No. 82: "The evident aim of the plan of the convention is that all the causes of the specified classes shall, for weighty public reasons receive their original or final determination in the courts of the union." 19 The powers over the federal judiciary that articles I and III gave to Congress thus involved authority over the distribution, organization, and implementation of the judicial power of the United States, not a license to curtail its exercise.

This thesis, it must be noted, is not completely synonymous with the often criticized theory advanced by Justice Story that Congress had a constitutional obligation to create inferior federal courts, ${ }^{20}$ although

18 While there is little evidence that the framers at the Philadelphia Convention intended any congressional power over the scope of jurisdiction of the entire federal judiciary, even when the amount in controversy was trivial, the debates during the ratification conventions suggested that Congress might exclude such trivial matters from the appellate jurisdiction of the Supreme Court. See infra notes 289-94, 327-30 and accompanying text. Since the ratification process was a part of the adoption of the Constitution, it might be argued that such a limited congressional power was thereby constructively engrafted onto the Constitution-a construction that serves to explain the seemingly inconsistent omission of certain classes of jurisdiction from the cognizance of the federal courts in the Judiciary Act of 1789, 1 Stat. 73 (current version codified in scattered sections of 28 U.S.G. (1976)). See infra notes 327-30 and accompanying text. During the ratification debates Federalist supporters of article III also conceded that Congress had power to curtail federal court review of facts to protect civil jury trials. See infra notes 198-219 and accompanying text.

19 The Federalist No. 82, at 556 (A. Hamilton) (J. Cooke ed. 1961). Cf. 3 J. Story, Commentaries on the Constitution of the United States 447 (1833) ("In regard to the power of constituting inferior courts of the Union, it is evidently calculated to obviate the necessity of having recourse to the Supreme Court in every case of federal cognizance.").

20. See Martin v. Hunter's Lessee, 14 U.S. (1 Wheat.) 304, 327-39 (1816); see also White v. Fenner, 29 F. Cas. 1015 (C.C.D.R.I. 1818) (No. 17,547); 3 J. STORY, supra note 19, at 435-56. See generally G. GunTHER, supra note 4, at 57-60; HART \& WECHSLER, supra note 3 , at 313-14.

Most of the contemporary scholars who have written on the question of congressional power over the scope of federal jurisdiction have focused on the existing case law and the contemporary constitutional policies surrounding these questions. Few have paid very close attention to the manner in which the debates at the Philadelphia Constitutional Convention and during the ratification process should affect the interpretation of article III. But see Sager, supra note 3. The interpretations of article III offered by Hamilton and some of the views expressed by Justice Story, which in part are supported by the historical material contained in this Article, have gained almost no support among contemporary writers on the subject. Indeed, the views of Hamilton and Story are frequently rejected without proper attention to the historical material that 
elements of this thesis are similar to views advanced by Story in Martin v. Hunter's Lessee ${ }^{21}$ and elsewhere. By the same token, this thesis does

supports their conclusions. See, e.g., Redish \& Woods, supra note 3, at 52-75.

By contrast, Professor Crosskey did advance and attempt to support some of the interpretations of article III offered by Hamilton and Story, although the historical support he advanced for his reading of the document was seriously lacking. See $I \mathrm{~W}$. Crosskey, Politics and the Constitution in the History of the United STATES 610-20, 641-74 (1953). Relying mostly on his own reading of the constitutional language and Hamilton's comments in The Federalist No. 82, Grosskey concluded:

The meaning of this requirement-that "the judicial Power shall extend to" all these "Cases," including those described in the enumeration as "Controversies"-is that the power in question "shall extend to" all the questions of law and fact of which these "Cases" consist. There can be no doubt about this, because the intention unmistakably is that the courts of the United States shall have power to decide the enumerated "Cases," and the national courts would not have such power, unless "the judicial Power" that is required to be "vested in" them did "extend to" the enumerated "Cases" in the complete sense just stated. Nevertheless, the view has been held that Congress, without offending these mandatory requirements of Article III, can except, from "the judicial Power" of the United States courts, various parts of the enumerated "Cases"; that is, various of the questions of law and fact of which these "Cases" consist. The notion seems to be that the Constitutional requirement is satisfied if "the judicial Power" is "extended to" any component of the enumerated "Cases." The words "extend to" are apparently read as "touch"; and a physical meaning is given to the words, in reference to a subject to which, it is clear, their physical meaning has no just application. For when this meaning is given them, the plain Constitutional intention that the national courts shall have power to decide the enumerated "Cases," and not merely some of the questions in them, is subverted.

The exaggerated notions that have come to be entertained of the power of Congress to make exceptions from the required "extent" of "the [national] judicial Power," and from the Supreme Court's Constitutionally conferred "suprem[acy]" in the exercise of that power, have rested, to be sure, in part, upon certain other provisions of Article III not yet noted. But although this is true, the notions in question have also rested, in part, upon the foregoing unwarranted views of the meaning of "extend to" in the second section of the article, and of the meaning of the omission of "all" in the categories of the judicial enumeration that are described as "Controversies." And this being true, it is essential to see that these views are unwarranted; that, so far, at least, as the provisions thus far considered are concerned, the "extension" of "the [national] judicial Power" to all the enumerated "Cases"-meaning all the questions of law and fact of which these "Cases" consist-was made mandatory upon Congress; and that the Supreme Court's Constitutionally conferred "suprem[acy]," in the exercise of the power required to have this "extent," was made mandatory upon Congress, too.

Id. at 615 (footnote omitted). Thus, Professor Crosskey viewed what he perceived to be the initial congressional decisions in the Judiciary Act of 1789 to withhold portions of the jurisdiction from the federal courts as unconstitutional decisions "contrived to slow down the process of change to [the article III] reforms." He found that such decisions by Congress withheld "from the courts it set up, certain of the powers that the Constitution, upon a straightforward reading, plainly makes mandatory for them." Id. at 610 .

2114 U.S. (1 Wheat.) 304 (1816).

The language of [article III] throughout is manifestly designed to be 
not mean that Congress was precluded from making exceptions to the appellate jurisdiction of the United States Supreme Court or to the

mandatory upon the legislature. Its obligatory force is so imperative, that congress could not, without a violation of its duty, have refused to carry it into operation. The judicial power of the United States shall be vested (not may be vested) in one supreme court, and in such inferior courts as congress may, from time to time, ordain and establish. . . .

Id. at 328. The opinion continued:

If, then, it is a duty of congress to vest the judicial power of the United States, it is a duty to vest the whole judicial power. The language, if imperative as to one part, is imperative as to all. If it were otherwise, this anomaly would exist, that Congress might successively refuse to vest the jurisdiction in any one class of cases enumerated in the constitution, and thereby defeat the jurisdiction as to all; for the constitution has not singled out any class on which Congress are bound to act in preference to others.

Id. at 330 .

Because Justice Story assumed that Congress had no control whatsoever over the jurisdiction of the state courts and could not mandate that they hear cases arising under federal law, he concluded that it was also mandatory for Congress to create inferior federal courts, id. at 330-37, and invest each article III court that it created with the whole of the judicial power of the United States. Since Congress can require the state courts to entertain federal causes of action, see Testa v. Katt, 330 U.S. 386 (1947), and since the framers demonstrably intended to vest discretion in Congress to create inferior federal courts and to distribute the exercise of judicial powers among them, Justice Story's conclusion with respect to the necessity for the creation of inferior federal courts is highly suspect. This defect in his analysis does not, however, invalidate his premise that the language of section 1 of article III imposed a mandatory obligation on Congress to vest the entirety of the judicial power of the United States in the federal judiciary as a whole.

Story's decision in Martin v. Hunter's Lessee did not, of course, ultimately turn on this premise, for he later addressed the issues posed in that case on the further assumption that Congress had discretion to refuse to create inferior federal courts or, if created, to refuse to vest in them the whole of the judicial power of the United States.

Story's argument that inferior federal courts were mandatory was presaged by a similar position taken by Gouverneur Morris, who, unlike Story, had attended the Philadelphia Convention. In a speech on the floor of the Senate on January 14, 1802, Morris argued that since the Supreme Court had no original jurisdiction and the Constitution "said that the judicial powers shall be vested in the supreme and inferior [federal] courts," the evident intent was that the cases would be tried in inferior federal courts. He concluded, "This, therefore, amounts to a declaration, that the inferior courts shall exist." 3 The Records of tHE Federal. Convention of 1787, 391 (M. Farrand ed. 1966) [hereinafter cited as Farrand, REConds].

The arguments offered by Gouverneur Morris and Justice Story may have been partially influenced, or at least anticipated, by earlier arguments offered by Alexander Contee Hanson of Maryland, who published federalist defenses of the Constitution under the pseudonymn Aristides during the ratification period. See Hanson, Remarks on the Proposed Plan of a Federal Government, in PAMPHLETs ON THE ConstituTION OF THE UNITED STATES 217 (P. Ford ed. 1888 \& republished 1968) [hereinafter cited as Ford, Pamphlets]. Not having attended the Philadelphia Convention and apparently ignorant of the Madisonian compromise, see infra notes 58-60 and accompanying text, Hanson assumed that Congress was constitutionally obligated to create the inferior federal courts and to invest them with original jurisdiction over all classes of cases that the Supreme Court was authorized to entertain in appellate form. Quite contrary to Justice Story's analysis in Hunter's Lessee, 14 U.S. (1 Wheat.) 304, how- 
original or appellate jurisdiction of the inferior federal courts. Rather, the central proposition advanced here is that the so-called exceptions and regulations clause and those clauses dealing with the congressional power to create inferior federal courts were intended by the framers to be construed in conformity with the overriding objective of the judicial article-to ensure that some federal court would have at least a discretionary opportunity to review each class of case enumerated in section 2 of article III, in order to ensure the supremacy of federal law and the national peace and harmony. That jurisdictional opportunity might involve either original or appellate determination in the federal courts. The power to make exceptions was at most an allocative authority designed to facilitate the creation of inferior federal courts.

Important to this jurisdictional scheme was the notion that the final appellate determination made by a federal court, even for a case originally tried in state court, could be made by an inferior federal court, rather than the Supreme Court. ${ }^{22}$ This point indicates that, from

ever, Hanson confidently asserted that an appeal could be taken to the Supreme Court only from decisions of the inferior federal courts. See infra note $\mathbf{2 7 0 .}$

${ }^{22}$ In The Federalist, Alexander Hamilton considered whether "an appeal [could] be made to lie from the state courts to the subordinate federal judicatories." He argued,

The plan of the convention in the first place authorises the national legislature "to constitute tribunals inferior to the supreme court." It declares in the next place that, "the JUDICIAL POWER of the United States shall be vested in one supreme court and in such inferior courts as congress shall ordain and establish"; and it then proceeds to enumerate the cases to which this judicial power shall extend. It afterwards divides the jurisdiction of the supreme court into original and appellate, but gives no definition of that of the subordinate courts. The only outlines described for them are that they shall be "inferior to the supreme court" and that they shall not exceed the specified limits of the federal judiciary. Whether their authority shall be original or appellate or both is not declared. All this seems to be left to the discretion of the legislature. And this being the case, I perceive at present no impediment to the establishment of an appeal from the state courts to the subordinate national tribunals; and many advantages attending the power of doing it may be imagined. It would diminish the motives to the multiplication of federal courts, and would admit of arrangements calculated to contract the appellate jurisdiction of the supreme court. The state tribunals may then be left with a more entire charge of federal causes; and appeals in most cases in which they may be deemed proper instead of being carried to the supreme court, may be made to lie from the state courts to district courts of the union.

The Federalist No. 82, at 556-57 (A. Hamilton) (J. Cooke ed. 1961) (footnote omitted). In suggesting that permitting appeals from the state courts would make possible the conditions necessary to curtail the jurisdiction of the Supreme Court, Hamilton again manifested his perception that the Philadelphia Convention had mandated that the whole of the judicial power of the United States be vested in the federal judiciary, albeit not necessarily in one particular court.

In some respects, the power now exercised by the federal district courts to entertain applications for writs of habeas corpus from state court criminal convictions functionally constitutes an exercise of the "appellate" power contemplated by Hamilton, 
the outset, the goal of assuring the supremacy of federal law and the supremacy of the federal government in areas of concern to more than one state was the central constitutional objective that the framers sought to implement through article III. Specifically, the structure established by the framers commanded that all cases raising issues of federal law or all cases concerning more than one state receive their final determination by federal judges not beholden to the states-judges who, unlike their state counterparts, were constitutionally guaranteed judicial independence. This structure also suggests that the objective of ensuring uniformity of interpretation of federal law, while desired by the framers as a matter of policy, was left substantially to congressional discretion and therefore was not a matter of constitutional imperative.

In demonstrating the historical support for a theory of mandatory federal jurisdiction, it seems most logical to present the material in its historical sequence. Thus, part II of this Article discusses the background and debates in the Constitutional Convention in Philadelphia regarding the structure of the federal judiciary, beginning with the experience under the Articles of Confederation and focusing thereafter on the debates at the Philadelphia Convention of 1787. Part III assesses the discussions of the federal judiciary during the process of ratification of the Constitution by the state conventions. This chronological presentation demonstrates that the framers' positions fluctuated as the focus of debate shifted from broad structural issues raised during the closed Constitutional Convention to more pointed attacks on the constitutional document raised during the open and well-publicized state ratification process. Nevertheless, the underlying interpretation of article III as creating a federal judiciary with constitutionally vested mandatory jurisdiction remained relatively unchallenged.

\section{The Intent of the Drafters of Article III AT the Philadelphia Convention}

\section{A. Background}

When the Convention convened in Philadelphia in 1787 to draft the nation's second written Constitution, the delegates were obviously not fabricating a new government out of whole cloth. Rather, they had the important experience of six years of formal operation under the Articles of Confederation and more than six years of earlier experience 
of governance by the Continental Congress without a formal constitutional document. This experience enlightened their perceptions of the need for structural change in the national governing processes. Exploring this earlier historical experience, therefore, is a prerequisite to understanding the perceptions of the drafters of the Constitution.

While the national government is sometimes thought of as lacking executive and judicial branches under the Articles of Confederation, national judicial proceedings predated the adoption of the Constitution in 1789 and were expressly provided for in the Articles in limited cases, such as cases adjudicating captures at sea in time of war. From the beginning, the Continental Congress faced the problem of disposing of such prize cases spawned by the hostilities with Great Britain. The Congress began by entertaining appeals in such cases, a total of sixtyfour in all, through special congressional committees that heard these cases and reported their judgments to Congress. ${ }^{23}$ Ultimately, a standing congressional committee was formed to hear the cases. ${ }^{24}$ On August 26,1779 , a committee was formed to consider establishing a more permanent court of appeal. ${ }^{25}$ Eventually, a plan was prepared and approved that established a court of three judges for the "trial" of appeals from state courts in cases of capture. ${ }^{28}$ This court, designated "The Court of Appeals in Cases of Capture," began operation on May 24, 1780 when the cases pending before the standing committee were transferred to the court docket. ${ }^{27}$ After approval of the Articles of Confederation in 1781, the Court of Appeals continued to operate under provisions of the Articles. ${ }^{28}$

Article 9 of the Articles of Confederation contemplated the exer-

283 Journals of the Continental Congress 1774-1789, 371-75 (W. Ford ed. 1905) [hereinafter cited as Journals]; 5 id. at 747. See generally J. Goebel, supra note 3 , at $147-82$.

247 JouRnALs, supra note 23 , at 75 .

25 The committee reported a plan for establishing "one or more supreme courts of appeal in all maritime causes." $15 \mathrm{id}$. at 1220-23. This plan went beyond the admiralty jurisdiction contemplated in the Articles of Confederation, which were then pending before the states. As noted below, article 9 only provided for national jurisdiction in "the trial of piracies and felonies committed on the high seas" and for hearing "appeals in all cases of captures." See infra note 29 and accompanying text. The initial plan reported to Congress called for the establishment of four districts within the United States, in each of which a national court of appeals was to be established to hear all appeals from the state admiralty courts within the district. No appeal was to be allowed when the appellant was "a subject or inhabitant" of the state where trial was held. After debate, which centered in part on the desirability of jury trial, the initial plan was defeated by an even division of the states. 17 JourNals, supra note 23, at 457-59.

so 17 Journals, supra note 23, at 457-59. See generally J. GoEBEL, supra note 3 , at $169-71$.

$27 \mathrm{~J}$. GoEBEL, supra note 3, at 171-82.

28 Id. at 171-73. 
cise of national judicial power both in certain maritime cases and in certain disputes between the states, but under procedures very different from those of the Court of Appeals. First, it provided that

[t]he united states in congress assembled, shall have the sole and exclusive right and power of . . . appointing courts for the trial of piracies and felonies committed on the high seas; and establishing courts for receiving and determining finally appeals in all cases of captures; provided that no member of Congress shall be appointed a judge in any of the said courts. $^{29}$

Second, article 9 provided that the Confederation Congress should serve as "the last resort on appeal, in all disputes and differences now subsisting, or that hereafter may arise between two or more States concerning boundary, jurisdiction, or any other cause whatever"so and for "[a]ll controversies concerning the private right of soil claimed under different grants of two or more states" that antedated any settlement of the jurisdiction and land claims between the affected states. ${ }^{31}$ This article also prescribed a ponderous procedure whereby such appeals were initiated upon petition to Congress by the legislature, governor, or lawful agent of any affected state. An ad hoc hearing tribunal was appointed by the parties or, when the parties could not agree on whom to appoint, by lot through a complex procedure in which the Congress chose nominees from all the states, and the parties were afforded a limited opportunity to peremptorily strike certain nominees. The judges were "to hear and finally determine the controversy, so always as a major part of the judges shall hear the cause shall agree in the determination." Their judgment was to be "final and conclusive," although they were limited by the requirement that their judgment could not deprive any state of territory for the benefits of the national government. The commissioners appointed under this article merely reported their decisions to Congress. Neither they nor the Confederation Congress had any power to implement or enforce their decisions. ${ }^{32}$

29 ARticles of Confederation art. 9, § 1.

The experience under this Court of Appeals was briefly noted by James Wilson during the debates at the 1787 Philadelphia Convention when he suggested that the jurisdiction of the proposed supreme court, like the Court of Appeals, should extend to "facts as well as law \& Common as well as Civil law." 2 Farrand, Records, supra note 21, at 431. One problem sometimes encountered by the Court of Appeals was that it had trouble enforcing its judgments when state courts simply ignored its reversals of their decisions. J. GoEBEL, supra note 3, at 179-81.

so ARTicles of Confederation art. 9, $\$ 2$.

s1 $I d$. art. $9, \S 3$.

s2 Id. art. $9, \S 2$. 
The judicial experience of the confederation is detailed elsewhere and will not be retraced here. ${ }^{3 s}$ That experience demonstrated, however, the value of a court, like the Court of Appeals, separate from the national legislature. The experience highlighted, among other things, the need to avoid the ponderous delay and inconvenience created by the ad hoc establishment of hearing tribunals, the importance of the national disposition of certain judicial cases to orderly diplomatic relations and to the domestic harmony of the states, the need for judges who could decide such questions independent of any obligations owed to the states that appointed them, and the extreme difficulty of enforcing national judgments affecting important state interests. Furthermore, the experience under these national adjudicatory procedures during the confederation period undoubtedly shaped the attitudes of the delegates who attended the Constitutional Convention in Philadelphia during the summer of 1787 and serves to explain the relative consensus surrounding the need for the establishment of a constitutionally created, standing, independent, national judiciary. The debate over the judiciary at the Philadelphia Convention therefore centered not on the issue of the creation of federal courts, but rather on the structure of those courts, the breadth of their jurisdiction, and the nature of their relationship to the already extant state courts.

\section{B. The Philadelphia Convention}

\section{Background}

Spawned by concerns over regulation of commerce, international diplomatic problems, and the need to ensure state compliance with the leadership of the national government in areas of international and interstate relations, and aided by the convening of the abortive Annapolis Convention, ${ }^{34}$ the Constitutional Convention first convened at Philadelphia on May 14, 1787, ultimately commencing work on May 25 . The Convention met irregularly through the summer of 1787 , adjourning from time to time as special committees hammered out the details of the constitutional document they were crafting, and concluded its deliberations with the signing of the document on Monday, September 17.

Under the rules adopted at the outset, the debates of the Convention were closed and could not "be printed, or otherwise published or

ss See, e.g., J. GoEBEL, supra note 3, at 182-95; Frank, supra note 3, at 7-9.

st See generally J. GoEBEL, supra note 3, at 196-200; A. KELLY, W. HARBIson \& H. Beiz, The American Constitution: Its Origins and Development 90-91 (6th ed. 1983). 
communicated without leave."3s By rule, a journal of the plenary proceedings was kept, listing major motions and votes. Unfortunately for our understanding of the judicial article, no similar record was kept of committee proceedings. Despite the rules forbidding publication of the debates, the available knowledge of the workings of the Convention is remarkable, consisting mainly of the journal, first published in 1819; James Madison's extensive notes, first published after some revisions by Madison in 1840; more fragmentary notes and accounts by Robert Yates, Rufus King, William Paterson, Alexander Hamilton, James McHenry, and William Pierce; and some surviving documents from the Convention and correspondence of its members. ${ }^{36}$

From these materials, it is clear that the establishment of a national judiciary was assumed by all delegates and only its contours and powers were periodically debated, although not extensively. The overall impression conveyed by these documents in that an independent national judiciary was seen as an essential means to enforce national authority and supremacy against recalcitrant state and private interests, to provide a neutral forum for cases that the states were individually incapable of resolving because of the perceived bias and lack of independence of their judges (referred to herein as matters of "transstate" concern), and to enforce constitutional constraints and protect individual liberties against federal and state legislative and executive branches. ${ }^{87}$

Initially, a number of plans for a new national government were formulated and presented to the Convention. On May 29, Edmund Randolph presented his so-called Virginia Plan, ${ }^{38}$ which proposed the establishment of an independent national judiciary consisting of "one or more supreme tribunals, and of inferior tribunals to be chosen by the

ss 1 Farrand, RecoRDs, supra note 21, at 17.

${ }^{36}$ Id. at xi-xxv.

37 From a review of the materials from the Philadelphia Convention, the state ratification conventions, and the related contemporaneous published letters and essays on the proposed Constitution, the author is firmly convinced that the framers clearly contemplated judicial review of both state and federal legislation, although the evidence supporting judicial review of state acts is far easier to find than data demonstrating an intent to institute judicial review of acts of Congress. The institution of judicial independence was defended on the ground that preservation of judicial autonomy was necessary if the federal courts were to perform the sensitive task of judicial review. See infra notes 93-108 and accompanying text. Similarly, the framers feared that the intrusion on the principle of separation of powers posed by uniting the judges with the Executive in the proposed Council of Revision would undermine the important function of judicial review. Id. The complete presentation of that material is beyond the scope of this piece, although some of the evidence is inextricably woven through the materials presented here. For a thorough historical exploration of the issue that also concludes that the framers intended judicial review of both state and federal legislation, see $\mathbf{R}$.

BERGER, supra note 3.

38 1 Farrand, RECORDS, supra note 21, at 16. 
National Legislature."'s9 As formulated by Randolph, the Virginia Plan would have constitutionally established the jurisdiction of the federal courts ("the jurisdiction of the inferior tribunals shall be to hear \& determine in the first instance, and of the supreme tribunal to hear and determine in the dernier resort"40). This jurisdiction included piracies and felonies on the high seas, capture cases, "cases in which foreigners or citizens of other States applying to such jurisdictions may be interested," national revenue cases, impeachments of national officers, and "questions which may involve the national peace and harmony." 1

The Virginia Plan, which ultimately became the focus of early Convention debate, also proposed the establishment of a Council of Revision $^{42}$ made up of the "Executive and a convenient number of the National Judiciary," which would have exercised authority to approve or reject statutes passed by national and state legislatures. ${ }^{43}$ Nowhere in the Virginia Plan was there any suggestion of legislative control over the jurisdiction of the national judiciary; the only proposed congressional power was limited to choosing the structure of the inferior tribunals, the existence of which were mandated by the plan.

The treatment of the judiciary in the other proposals is also illuminating. On the same day that the Randolph proposal was offered, Charles Pinckney of South Carolina presented a plan ${ }^{44}$ that called for the mandatory creation of both a supreme court and such inferior fed-

\footnotetext{
ss Id. at 21 .

40 Id. at 22 (emphasis added).

4 Id.

42 The proposal stated:
}

8. Resd. that the Executive and a convenient number of the National Judiciary, ought to compose a council of revision with authority to examine every act of the National Legislature before it shall operate, \& every act of a particular Legislature before a Negative thereon shall be final; and that the dissent of the said Council shall amount to a rejection, unless the Act of the National Legislature be again passed, or that of a particular Legislature be again negatived by ... of the members of each branch.

Id. at 21 (ellipsis in original).

This proposal may have been drawn from the review powers of certain state councils that may in turn have originated in the dual power the English Privy Council exercised separately through its judicial appellate jurisdiction and its veto authority over colonial legislation. For an example of provisions for a state council, see N.Y. Const. art. 3 (1777), in 2 B. Poole, The Federal and State Constitutions, Colonial Charters, and Other Organic Laws of the United States 1332-33 (1877). For a survey of the colonial experience with the Privy Council, see generally J. Smith, Appeals to the Privy Council from the American Plantations (1950).

48 1 Farrand, Records, supra note 21, at 21.

4t Id. at 16, 23. 
eral courts "as shall be necessary." 45 Two weeks later, on Friday, June 15, after extensive debate on the Virginia Plan, William Paterson presented the so-called New Jersey Plan, which provided for an independent national supreme court appointed by the Executive with constitutionally established jurisdiction ("the Judiciary so established shall have authority to hear \& determine") over impeachments of federal officers, cases touching the rights of ambassadors, capture cases, piracies and felonies on the high seas, all cases in which foreigners might be interested, and cases involving the construction of treaties or which might arise from the national revenue or commerce laws. ${ }^{46}$ In impeachment cases the supreme court's jurisdiction was to be original; all other cases were to be heard by the supreme court "in the dernier resort" from the state courts. ${ }^{47}$ Like the Virginia Plan, the Paterson proposal contained no suggestion whatsoever of any congressional control over the jurisdiction of the supreme court. Its major distinguishing characteristics were its deliberate omission of any inferior federal courts ${ }^{48}$ and its provision for the appointment of the judges by the Executive, rather than by the national legislature, as in the Virginia Plan, or by the Sen-

45 The text of the Pinckney Plan is set forth in $3 \mathrm{id}$. at 600 ; see also $2 \mathrm{id}$. at 13437 (outline of Pinckney Plan).

$481 \mathrm{id}$. at 244.

47 Id.; see also 3 id. at 611-15 (text and discussion of New Jersey Plan).

18 Paterson proposed to have the state courts try all cases except impeachments of national officers in the first instance. In order to resolve the problem of ensuring federal supremacy, Paterson proposed a supremacy clause:

6. Resd. that all Acts of the U. States in Congs. made by virtue \& in pursuance of the powers hereby \& by the articles of confederation vested in them, and all Treaties made \& ratified under the authority of the $U$. States shall be the supreme law of the respective states so far forth as those Acts or Treaties shall relate to the said States or their Citizens, and that the Judiciary of the several States shall be bound thereby in their decisions, any thing in the respective laws of the Individual States to the contrary notwithstanding .... .

1 id. at 245. As amended, Paterson's suggested supremacy clause ultimately found its way into article VI of the Constitution. The fact that the clause was first suggested during the Convention in a plan that did not call for inferior courts and was suggested to assure state court adherence to the principle of national supremacy helps explain why the clause ultimately adopted refers only to state judges without mentioning the federal judiciary. It should be noted that the idea of a supremacy clause did not originate with Paterson. Article 13 of the Articles of Confederation had provided in part: "Every State shall abide by the determination of the United States in Congress assembled, on all questions which by this confederation are submitted to them. And the articles of this confederation shall be inviolably observed in every State . . . ARTICLes of Confederation art. 13. As Alexander Hamilton noted, however, in The Federalist, a central problem with the confederation was that there was "no power to exact obedience" to this provision. THE FEDERALIST No. 21, at 129 (A. Hamilton) (J. Cooke ed. 1961). The innovation made by the Paterson plan was that it rendered the political issue of state compliance with federal law a justiciable legal question and specifically directed the state courts to enforce federal supremacy. 
ate, as proposed by Pinckney.

Other plans were prepared but never submitted to the Convention. The manuscript of a plan drafted by Alexander Hamilton shows that Hamilton favored creation of a supreme court with extensive original jurisdiction over controversies involving the United States; the United States and a particular state, or two or more states; and over cases affecting foreign ministers and consuls. The Supreme Court also would have had appellate jurisdiction "both as to law and fact" in cases concerning citizens of foreign nations, questions between citizens of different states, "and in all others in which the fundamental rights of this Constitution are involved, subject to such exceptions as are herein contained and to such regulations as the Legislature shall provide."49 Under Hamilton's plan, controversies about land rights between the United States and any state were to be submitted to a more neutral special hearing commission chosen in a manner vaguely reminiscent of the commissions for disputes between the states under the Articles of Confederation. Inferior federal courts were not expressly mentioned in the Hamilton plan and apparently were left to congressional discretion since the plan referred to "Judges of all Courts which may be constituted by the Legislature" and further stated that "nothing herein contained shall be construed to prevent the Legislature from abolishing such [inferior] Courts themselves."

Thus, all of the plans for a new national government called for the establishment of an independent national judiciary consisting of at least one supreme court with constitutionally established jurisdiction and, in some plans, inferior federal courts. While many of the plans assumed the necessity for legislative implementation of a court structure, the only suggestion of any congressional power over the judicial establishment came in the stillborn Hamilton plan that apparently left the creation of inferior federal courts to congressional control and authorized the national legislature to make regulations, but not exceptions, governing the exercise of original and appellate jurisdiction by the supreme court. $^{\text {s1 }}$

193 Farrand, RECoRDS, supra note 21 , at 626 . The plan was apparently drafted for a speech Hamilton delivered on June 18, 1787. While not formally presented to the Convention, the Hamilton plan may have influenced the final document.

${ }^{50}$ Id.

Yet another plan was found among the papers of George Nason of Virginia. The plan called for the creation of a supreme court and lower federal courts of only admiralty jurisdiction. $2 \mathrm{id}$. at 432-33; HART \& WECHSLER, supra note 3 , at 3.

62 The Supreme Court shall have . . . an appellate jurisdiction both as to law and fact in all cases which shall concern the Citizens of foreign nations, in all questions between the Citizens of different States, and in all others in which the fundamental rights of this Constitution are involved, 
Not only were these plans wholly silent on the subject to legislative power over court jurisdiction, but they also uniformly evidenced an intent on the part of the framers to assure judicial independence from Congress and the Executive by providing that the judges of the national courts would "hold their offices during good behaviour" and receive fixed salaries which could not be diminished during their terms of office. The indicia contained in these plans seem to belie any suggestion that important factions in the Philadelphia Convention favored congressional control over the powers of the national judiciary, either as a constitutional check on the judiciary or because they supported the principle of legislative supremacy. Rather, both nationalists, like Randolph and Hamilton, and more pro-state delegates, like Paterson, initially seem to have been united in a desire to create an independent national judiciary consisting of at least a supreme court with constitutionally established jurisdiction. There was even substantial agreement on the types of cases to be overseen by the national judiciary, which is surprising since the jurisdiction envisioned was considerably greater than that committed to national judicial attention under the Articles of Confederation. These initial proposals differed only on the need for and manner of creation of inferior federal courts and in the manner of appointment of federal judges.

\section{Early Deliberations and the Adoption of General Principles Governing a Federal Judiciary}

Only Randolph's Virginia Plan and Paterson's New Jersey Plan were actually discussed by the Convention in its early deliberations as a committee of the whole. The debates during this period reflect a broad commitment to an independent judiciary with wide-ranging constitutionally established jurisdiction over disputes affecting national laws, international affairs, and matters of transstate concern. In presenting his plan on May 29, Randolph apparently urged the necessity of two "Checks upon the Legv. and Ex. Powers"-his Council of Revision and the national judiciary. ${ }^{52}$ His plan for a national judiciary consisting of one supreme tribunal and one or more inferior courts was tentatively

subject to such exceptions as are herein contained and to such regulations as the Legislature shall provide.

3 Farrand, ReCORDS, supra note 21, at 626; see infra note 144 and accompanying text.

82 1 Farrand, Records, supra note 21, at 28 (Paterson's notes). Thus, from the beginning of the Convention, the federal judiciary was seen as a necessary independent check on the federal legislature, a fact that casts serious doubt on the framers' willingness to accept legislative power or control over the scope of jurisdiction of the national courts. 
but unanimously approved without debate on June 4, but the question of whether to add the judges to the proposed Council of Revision was postponed at Hamilton's urging. ${ }^{\text {ss }}$

The next day, June 5, the opponents of inferior federal courts, who consisted mostly of delegates from small states, regrouped and launched their attack. Under their influence, the Convention first agreed to eliminate the reference to the number of inferior courts from the plan under consideration and then voted, eight states to two, to reject the idea of judicial appointment by the national legislature. ${ }^{54}$ During this debate, the provisions of Randolph's plan calling for guarantees of judicial independence were unanimously adopted without debate.

After considering other matters, the Convention returned to the proposals on the judiciary when John Rutledge of South Carolina moved, seconded by Roger Sherman of Connecticut, to strike the reference in the plan to inferior federal courts. Rutledge argued that "the State Tribunals might and ought to be left in all cases to decide in the first instance the right of appeal to the supreme national tribunal being sufficient to secure the national rights \& uniformity of Judgmts: that it was making an unnecessary encroachment on the jurisdiction [of the States,] and creating unnecessary obstacles to their adoption of the new system." "The motion passed, five states (Connecticut, New Jersey, the Garolinas, and Georgia) to four (Pennsylvania, Delaware, Maryland, and Virginia), with two state delegations (Massachusetts and New York) divided. ${ }^{.7}$ This unexpected turn of events prompted what has often been described as the Madisonian compromise when James Wilson and John Madison moved, apparently at the suggestion of John Dickinson of Delaware, that the national legislature be "empowered to institute inferior tribunals." the national government to create lower federal courts, they stressed "that there was a distinction between establishing such tribunals absolutely, and giving a discretion to the Legislature to establish or not establish them." While Pierce Butler of South Carolina objected that, even if such lower federal courts were useful, the states would not bear

ss Id. at 93-95, 108-09; see also id. at 104-05.

st Id. at 116. Wilson and Pinckney reserved the right to reconsider the first and second of these decisions respectively. Madison, who disliked selection of judges by "any numerous body," but who also distrusted the Executive, suggested selection by the Senate. Id. at 120-21.

${ }^{\mathrm{BS}} \mathrm{Id}$. at 121 .

so Id. at 124 .

s7 Id. at 125.

s8 Id. at $125,127$.

so Id. at 125 . 
such encroachments on their sovereignty, and that their cost would be much higher than merely providing for appeals to the supreme court, the Madisonian compromise carried the day by a vote of seven states to three (the compromise capturing Massachusetts from the camp of the divided and turning around the North Carolina and Georgia delegations). ${ }^{60}$ With the rapid adoption of Madisonian compromise during the eighth business session of the Convention, the outer parameters of the judicial article were established in principle, though debate continued over its internal structure and arrangement.

On June 12 and 13, the Convention again turned its attention to the judiciary article, this time focusing on the scope of jurisdiction of the national judiciary. On the first day of this debate, the delegates agreed to strike all references to jurisdiction over piracies, felonies on the high seas, and capture cases, ${ }^{61}$ a somewhat surprising development since appellate jurisdiction over the latter class of cases was at that time exercised by a national Court of Appeals under the Articles of Confederation. It is possible that the more pro-state delegates may have decided, after the success of the Madisonian compromise, to attack the judicial article by whittling away at the jurisdiction of the national judiciary.

The strong federalists in the Convention, like Randolph and Madison, must have sensed this stratagem, since they launched their own counterattack the next day by moving to amend Randolph's original plan from a particularized to a more general statement of the jurisdiction of the proposed national judiciary. The amended plan offered by Randolph and Madison provided " $[t]$ hat the jurisdiction of the national Judiciary shall extend to cases which respect the collection of the national revenue, impeachments of any national officers, and questions which involve the national peace and harmony." 62 This amendment was significant not only because it thwarted the efforts to pare the more particularized jurisdiction in the original Virginia Plan, but also because it brought the projected grant of power to the national judiciary into conformity with the proposed grant of legislative authority to Congress. The legislative provision of the Virginia Plan, as then drafted, granted Congress the right

to enjoy the legislative rights vested in Congress by the confederation; and moreover.

to legislate in all cases to which the separate States are in-

so Id.

e1 Id. at $211,220$.

${ }_{62} I d$. at 223-24; see also id. at 232-33 (debate over and adoption of amendment). 
competent: or in which the harmony of the United States may be interrupted by the exercise of individual legislation. to negative all laws passed by the several States contravening, in the opinion of the national legislature, the articles of union; or any treaties subsisting under the authority of the Union[.] ${ }^{63}$

The conformity of the two provisions suggests that the framers were attempting to assure that the judicial power was coextensive with the legislative power, as had often been advocated, ${ }^{\text {at }}$ and that two separate national bodies, the Congress and the federal courts, could each separately deal with the major problems of the union-assuring individual state compliance in areas of international and transstate concern.

On June 13 the framers also briefly returned to the vexing problem of the manner of appointment of federal judges, ultimately voting, at Madison's insistence, for appointment by the Senate, which was "a less numerous \& more select body, would be more competent judges, and which was sufficiently numerous to justify such a confidence in them."

Thus, as it emerged from the first round of consideration by the committee of the whole, the portions of the Virginia Plan dealing with the judiciary had been amended to read:

11 Resolved. that a national judiciary be established to consist of

\section{One supreme Tribunal}

The Judges of which to be appointed by the second Branch of the National Legislature.

to hold their offices during good behaviour

to receive, punctually, at stated times, a fixed compensation for their services: in which no encrease or diminution shall be made so as to affect the persons actually in office at the time of such encrease or diminution

12 Resolved. That the national legislature be empowered to appoint

inferior Tribunals.

os Id. at 225 .

68 See, e.g., The Federalist No. 8, at 535 (A. Hamilton) (J. Cooke ed. 1961) ("If there are such things as political axioms, the propriety of the judicial power of a government being co-extensive with its legislative, may be ranked among the number.").

es 1 Farrand, Records, supra note 21, at 233. 
13 Resolved. that the jurisdiction of the national Judiciary shall extend to cases which respect the collection of the national revenue: impeachments of any national Officers: and questions which involve the national peace and harmony. ${ }^{68}$

This plan, which was intended, according to Randolph, to preserve "the security of foreigners where treaties are in their favor, and to preserve the harmony of states and that of the citizens thereof,"67 only mapped out general principles and was referred to the Committee of Detail for a draft document effectuating its provisions.

The plan contained no suggestion whatsoever of any congressional authority over the jurisdiction of either the supreme or inferior courts, that jurisdiction being constitutionally established in the Randolph resolutions. Rather, the only congressional discretion explicitly countenanced was the power to decide whether to institute lower federal courts. It seems, therefore, that the framers did not assume that with the power to establish inferior federal courts necessarily went the power to control their jurisdiction.

Believing it had completed its review of the Virginia Plan, the committee of the whole was preparing to vote to report the amended plan to the floor of the Convention when the pro-state delegates again counterattacked on June 15, this time with Paterson's presentation of the New Jersey Plan. ${ }^{68}$ This plan, as noted earlier, called for the establishment of a supreme court with a constitutionally specified jurisdiction and no inferior federal courts. ${ }^{68}$ The Paterson resolutions also called for appointment of the judges by the Executive, rather than by the whole Congress, where the votes of the representatives from the smaller states would be far outnumbered by representatives from more populous states.

This development extended the deliberations of the committee of the whole for several days, until June 19, and provoked an extensive comparison of the advantages of the two plans. On June 18, Alexander Hamilton advanced his own ideas in an extensive speech that closely tracked the structure of the amended Virginia Plan. ${ }^{70}$ The next day, Madison rose to attack the New Jersey Plan, complaining that it was

Id. at $230-31$.

6r Id. at 238 (Yates's notes).

68 Id. at 241-45.

-9 See supra notes 46-48 and accompanying text.

701 Farrand, RECORDS, supra note 21, at 282-311. Hamilton's own plan, which he never presented to the Convention, was apparently prepared in contemplation of the delivery of this speech. It might be surmised that Hamilton's decision not to present his own plan was based on the view that the Virginia Plan, as it then stood, accomplished most of Hamilton's objectives. 
"particularly defective in two of its provisions."71 First, it provided for ratification by the state legislatures and not the people, thereby perpetuating the worst features of the confederation. Second, Madison objected to the omission of inferior federal courts from the judiciary provision, reasoning that this would allow excessive opportunity for state interference with federal supremacy. Such interference could result from both "undue acquittals in the State tribunals" without any subsequent opportunity to appeal and the exercise of the state pardon power by state governors. ${ }^{72}$ On June 19 , by a vote of seven states to three, with one state divided, the committee of the whole voted to report the amended Virginia Plan to the Convention and to disapprove of Paterson's New Jersey Plan. ${ }^{28}$ Only Luther Martin spoke up in support of the judiciary structure proposed in the New Jersey Plan, noting that "a national Judiciary extended into the States, would be ineffectual, and would be viewed with a jealousy consistent with its usefulness."74

Debate on the judiciary provisions of the amended Virginia Plan was undertaken on the floor of the Convention on July 18, and the Convention rapidly and unanimously decided that a national judiciary should be adopted, consisting of at least one supreme tribunal. ${ }^{75}$ The judges of that tribunal would hold their offices during good behavior and receive a fixed salary for their services. Furthermore, no decrease could be made to affect the salaries of those then holding judicial office. ${ }^{78}$ After an extensive and inconclusive debate over the procedure for appointment of federal judges, ${ }^{77}$ the Convention voted to further amend the report of the committee of the whole by eliminating the proscription against increasing judicial salaries during a judge's term of office. ${ }^{78}$ Gouverneur Morris of New York and Benjamin Franklin of Pennsylvania supported this change because of the possibility of inflation and the likelihood that the business of the national judiciary would increase as the population of the nation grew. Morris carefully noted, however, that such a change "would not create any improper dependence in the Judges." dence will be less" with the power only to increase salaries, he nevertheless unsuccessfully opposed the motion because of its potential for

72 Id. at 317.

72 Id.

73 Id. at $322,328$.

34 Id. at 341.

362 id. at 37, 41.

36 Id. at $38,44$.

77 Id. at 37-38, 41-44.

78 Id. at 38, 44-45.

70 Id. at 44 . 
fostering judicial reliance upon legislative largess, thereby diminishing the independence of the national judges. ${ }^{80}$ Madison stated,

Whenever an increase is wished by the Judges, or may be in agitation in the legislature, an undue complaisance in the former may be felt towards the latter. If at such a crisis there should be in Court suits to which leading members of the Legislature may be parties, the Judges will be in a situation which ought not to [be] suffered, if it can be prevented. ${ }^{81}$.

Thus, the framers again demonstrated their strong insistence upon the independence of the national judiciary from legislative control. After approval of this amendment, the Convention approved the judiciary provision contained in the eleventh clause of the committee report. ${ }^{\mathbf{8 2}}$

The Convention then moved to the controversial twelfth clause authorizing the Congress to "appoint" inferior federal courts. ${ }^{83}$ Butler urged that such courts were unnecessary, as the "State Tribunals might do the business." Concurring, Martin accurately predicted that the inferior federal courts would "create jealousies \& oppositions in the State tribunals, with the jurisdiction of which they will interfere."84 Gorham of Massachusetts noted that neither the states nor their courts had complained about the already extant national Court of Appeals and argued that "[i]nferior Tribunals are essential to render the authority of the Natl. Legislature effectual."85 This argument is evidence of the central importance to the framers of enforcing national authority through the federal judiciary. Further evidence of that concern was Randolph's comment that "the Courts of the States can not be trusted with the administration of the National laws. The objects of jurisdiction are such as will often place the General \& local policy at variance."86 Gouverneur Morris, Sherman, and Mason all spoke to support the twelfth clause, and it was agreed to without record vote. ${ }^{87}$

Thereafter, the Convention turned to the jurisdiction of the national judiciary established in the thirteenth clause of the amended Virginia Plan. After deleting the jurisdiction over impeachment of national officers, ${ }^{88}$ it adopted without debate a resolution proposed by Madison

${ }^{80}$ Id. at 45.

81 Id.

82 Id. at 38, 45; see supra text accompanying note 66 .

83 See supra text accompanying note 66.

84 2 Farrand, ReCoRDs, supra note 21, at 45, 46 (Butler and Martin respectively).

${ }^{8 s} I d$. at 46.

Id. at 46.

Id.

s8 Id. at $39,46$. 
providing that "the jurisdiction shall extend to all cases arising under the Natl. laws: And to such other questions as may involve the Natl. peace \& harmony." ${ }^{\text {89 }}$ Finally, after a brief discussion of other details, ${ }^{90}$ the modified Virginia Plan was referred to the Committee of Detail on July $26^{91}$

At this point the Convention's directives still called for an independent national judiciary with constitutionally established jurisdiction and a strong wall of separation from the legislative branch. ${ }^{92}$ The only delegated congressional power over the judiciary, in addition to the power to appoint judges, was the power to establish inferior federal courts, and that power had emerged only as a compromise between those delegates who wanted constitutionally established lower federal courts and those who desired to leave the trial of all cases of national magnitude to state tribunals in the first instance. There is no record that even one word supporting the general principle of congressional control over the judiciary had been spoken in the two months of Convention debates. Indeed, the grant of jurisdiction to the national judiciary was still contained in a separate resolution, the thirteenth, that said nothing whatsoever about congressional power. It is, thus, again evident that the framers did not entertain the idea that the legislative power to establish inferior federal courts necessarily included congressional control over the scope of those courts' jurisdiction.

\section{Debate over the Council of Revision}

During the early deliberations on the Virginia Plan, the Convention, as a committee of the whole, transformed Randolph's proposal for a Council of Revision-a plan that united executive and judicial officials into a reviewing body that would make the final decision accepting or rejecting statutes adopted by Congress-solely into an executive veto mechanism by rejecting judicial participation in the process. The now famous debates on the Council of Revision are of vital significance because they demonstrate the contemplation by some of the important delegates of horizontal judicial review, ${ }^{93}$ that is, review by the national courts of the constitutionality of acts of Congress or the Executive. ${ }^{94}$

89 Id. at 46.

90 Id. at 116-17, 121-26 (referral to the Committee of a proposal to require qualifications of property and citizenship for judges and other federal officials).

91 Id. at 128; see infra text accompanying notes 109-48.

92 Farrand, RECORDS, supra note 21, at 132-33.

${ }^{93}$ See, e.g., 1 id. at 97-98 (comments of Elbridge Gerry). See generally R. BERGER, supra note 3, at 50-81, 154-65 (analysis of the framers' discussions).

4 Cf. 2 Farrand, RecoRDS, supra note 21, at 298 (comments of John Mercer) ("He disapproved of the Doctrine that the Judges as expositors of the Constitution 
The debates are also of some importance to the issue of congressional power over federal court jurisdiction, further indicating that the framers were concerned with zealously protecting the independence of the judiciary. On June 4, Elbridge Gerry of Massachusetts, an opponent of any limitation on the power of the legislature, rose to attack the Randolph Council of Revision proposal insofar as it implicated the judiciary, stating that he doubted

whether the Judiciary ought to form a part of ... . [the Council of Revision], as they will have a sufficient check agst. encroachments on their own department by their exposition of the laws, which involved a power of deciding on their Constitutionality. In some States the Judges had [actually] set aside laws as being agst. the Constitution. This was done too with general approbation. It was quite foreign from the nature of ye. office to make them judges of the policy of public measures. ${ }^{98}$

Rufus King observed that "the Judges ought to be able to expound the law as it should come before them, free from the bias of having participated in its formation."96 Wilson, an ardent supporter of a strong national judiciary, joined the opposition to the Council of Revision because he thought the legislative, executive, and judicial departments "ought to be distinct \& independent" and the Executive ought to exercise an absolute veto. ${ }^{97}$ Ultimately, after extensive debate, the committee agreed to exclude the judiciary from the Council of Revision and to give the veto power to the Executive, subject to overruling by twothirds of each house of Congress. ${ }^{98}$

Fearing "the great difficulty in rendering the Executive competent to its own defence" against a democratically elected legislature, Madison, on June 6, seconded a motion by James Wilson to reconsider this exclusion of the judiciary from the Council of Revision. ${ }^{99}$ Madison made a long plea for judicial participation, urging that "[a]n association of the Judges in his revisionary function wd both double the advantage and diminish the danger. It wd. also enable the Judiciary Department the better to defend itself agst. Legislative encroachments."100 Thus,

should have authority to declare a law void. He thought laws ought to be well and cautiously made, and then to be uncontroulable.").

${ }^{95} 1$ id. at $97-98$.

${ }^{20} \mathrm{Id}$. at 98.

97 Id; see also id. at 100 (explanation of Wilson's rationale).

${ }^{88}$ Id. at 94, 103-04.

Id. at 138; see id. at 131 (record of the motion).

$100 \mathrm{Id}$. at 138. 
both supporters and opponents of judicial participation in the Council of Revision were apparently concerned with maintaining a strict separation of legislative and judicial powers and with preventing Congress from encroaching upon the constitutionally established powers of the federal judiciary. While recognizing that including both the executive and the judiciary in the proposed council violated the spirit of the Concept of separation of powers, Madison observed that this objection applied with equal weight to executive veto of acts of Congress and to "revision of the laws" by the judiciary, namely, to horizontal judicial review. ${ }^{101} \mathrm{He}$ therefore concluded that

whether the object of the revisionary power was to restrain the Legislative from encroaching on the other co-ordinate Departments, or on the rights of the people at large; or from passing laws unwise in their principle,' or incorrect in their form, the utility of annexing the wisdom and weight of the Judiciary to the Executive seemed incontestable. ${ }^{102}$

While incontestable for Madison, the principal was again opposed by Gerry, King, Pinckney, and Dickinson, in part because it "involved an improper mixture of powers," and Wilson's motion to reconsider the exclusion of the judiciary from the Council of Revision lost, three states to eight. ${ }^{103}$

The effort to include the judiciary in the review and approval of acts of Congress briefly resurfaced late in the Convention when, on August 15, Madison moved that all laws passed by Congress be submitted to both the Executive and the Supreme Judiciary Department. If either objected, they could be overruled by a two-thirds vote of each house of Congress; if both objected, by a three-fourths vote of each house. ${ }^{104}$ While this proposal seemingly obviated the objection to the intermixture of executive and judicial powers, Pinckney nevertheless opposed it, objecting to "the interference of the Judges in the Legislative business: it will involve them in parties, and give a previous tincture to their opinions."105 Gerry suggested that the plan was just "the same thing" as the rejected Randolph proposal. ${ }^{106}$ Only John Mercer

$101 \mathrm{Id}$. at 139.

102 Id.

103 Id. at $139-40$.

1042 id. at $294-95,298$. The idea for this proposal may have originated in a comment made by James Wilson during the June 4 debate in which he suggested that "[h]e was for varying the [Council of Revision] proposition in such a manner as to give the Executive \& Judiciary jointly an absolute negative." 1 id. at 98.

1052 id. at 298.

${ }^{108}$ Id. 
of Maryland added a new voice of support to the debate. While noting that he "disapproved of the Doctrine that Judges as expositors of the Constitution should have authority to declare a law void," he heartily supported Madison's ideas because they would prevent "legislative usurpation and oppression." 107 Mercer argued that it was "an axiom that the Judiciary ought to be separate from the Legislative: but equally so that it ought to be independent of that department."108 The concern with maintaining a separate, independent judicial department was thus once again evidenced by both supporters and opponents of involvement of the judiciary in the Council of Revision and by both advocates and critics of the institution of judicial review. This striking consensus for protecting the independence and neutrality of the federal judiciary, makes it seem highly doubtful that the framers, at this stage of the proceedings, would have countenanced, much less intended, any congressional control over the jurisdiction and powers of the national judiciary.

\section{The Committee of Detail and the Drafting of a Judicial Article}

On July 23, the Convention unanimously established a five member Committee of Detail to which the proceedings of the Convention were referred "for the purpose of reporting a Constitution conformably to the Proceedings aforesaid." 100 The Committee was not charged with presenting new structural solutions to problems, but rather, as its name suggests, was merely directed to convert the Convention's general statements of structural principles into a draft document. Given this charge, it would be most appropriate to interpret the skimpy records and results of this Committee's deliberations to conform to the pre-existing deliberations and instructions of the Convention. This observation is significant, because many of the basic and important decisions affecting the language, if not the structure, of article III of the Constitution were made by the Committee of Detail. While minutes or journals of the debates of this Committee have never been located, fragmentary draft documents permit some reconstruction of the events which culminated in the proposed draft of the judiciary article.

The Committee of Detail may have initially encountered difficulty in making more specific the general grant of federal court jurisdiction approved by the Convention, i.e., jurisdiction over "cases arising under the Natl. laws: And to such other Questions as involve the Natl. peace

107 Id.

108 Id.

109 Id. at 85; see also id. at 95-96 (discussion of committee's composition). 
\& harmony."110 The Committee first considered and then rejected a proposal which would have given Congress power to particularize the jurisdiction. This proposal was the first suggestion during the Convention of any congressional control whatsoever over the federal court jurisdiction. An early draft of this proposed provision made by Edmund Randolph, with notations by John Rutledge, stated:

7. The jurisdiction of the supreme tribunal shall extend

1. to all cases, arising under laws passed by the general [Legislature]

2. to impeachments of officers, and

3. to such other cases, as the national legislature may assign, as involving the national peace and harmony, in the collection of the revenue, in disputes between citizens of different states

[in disputes between a State \& a Gitizen or Gitizens of another State]

in disputes between different

states; and

in disputes, in which subjects or citizens of other countries are concerned

[\& in Gases of Admiralty Jurisdn]

But this supreme jurisdiction shall be appellate only, except in [Cases of Impeachmt. \& (in)] those instances, in which the legislature shall make it original. And the legislature shall organize it

8. The whole or a part of the jurisdiction aforesaid according to the discretion of the legislature may be assigned to the inferior tribunals, as original tribunals. ${ }^{111}$

110 Id. at 46.

111 Id. at 146-47. The document was found among George Mason's papers. The main portion of the text is in Randolph's handwriting. The material shown in parentheses was crossed out in the original, and the material shown in brackets represents emendations in Rutledge's handwriting. The words in italics were changed by Randolph. Id. at 137 n.6.

Amidst the documentary litter of history, another curious document has emerged proposing to grant Congress power both to create a supreme court and such inferior federal courts as it deemed appropriate and also to "ascertain their respective powers and jurisdictions." This document was found among the papers of Roger Sherman of Connecticut and contained several constitutional propositions. $3 \mathrm{id}$. at 615-16. (The full text of the proposition is set forth in the Appendix.) Farrand notes that there is serious doubt whether this document was prepared for or at the Philadelphia Convention, or rather was drafted long after the Convention, while Sherman served in Congress, to 
It should be noted that this draft contained two very distinct types of congressional power. First, it authorized congressional control over the scope of jurisdiction of the national judiciary by allowing Congress to "assign" to the supreme court cases within certain categories of questions involving "the national peace and harmony." It also authorized Congress to assign to the inferior federal courts it created the "whole or a part" of the national judicial power. Second, it empowered Congress to structure the federal judiciary and distribute its powers. This was accomplished first by allowing Congress to authorize the supreme court to exercise original jurisdiction over cases which it could otherwise only hear in appellate form, second by allowing Congress to "organize" the appellate jurisdiction of the Court (i.e., provide rules of practice and procedure), and third by authorizing Congress, to create inferior federal courts "as original tribunals."112 The draft exhibits very careful word choice, consistently using the mandatory "shall extend" in defining the court's jurisdiction and "shall organize" regarding the distribution between appellate and original jurisdiction of the supreme court. In contrast, the draft invoked the discretionary "may assign" or "may be assigned" where congressional discretion was clearly intended, ${ }^{113}$ i.e., in

reflect proposed amendments he wanted to see in the constitutional scheme. Sherman's major biographer, L.H. Boutell, treats the document as embodying amendments that Sherman deemed appropriate in the existing government. L. BouTELL, LIFE OF Roger Sherman 132 (1896), discussed in 3 Farrand, REcoRds, supra note 21, at 615. Others, including Farrand, however, disagree. Id. In light of the disputed and dubious origin of this document and because the document was not presented to the Convention and, unlike the Hamilton Plan, played no evident role in the later drafting of the Constitution, the document is not further discussed in this Article.

Even if further authentication could prove that the Sherman document originated during the time of the Philadelphia Convention, such. evidence would probably do little to change the conclusions of this Article, since Sherman played a minimal role in the formation of the judicial article and because Sherman and the Connecticut delegation generally seemed to favor, albeit unsuccessfully, the proposals for a limited judiciary offered in Paterson's New Jersey Plan. Indeed, Farrand speculatively regards this document as "probably presenting the ideas of the Connecticut delegation in forming the New Jersey Plan." Id. Thus, the Sherman proposals, at most, represent the views of the losers in the debates over the formation of the judicial article.

112 Farrand, RECORDS, supra note 21, at 147.

113 During the Committee deliberations, James Wilson also developed, and possibly presented, a number of fragmentary drafts of a constitutional document. One of those drafts, bearing the unexplained title, "An Appeal for the Correction of all Errors both in Law and Fact," called for a judiciary with constitutionally established jurisdiction, including jurisdiction over cases arising under "the Law of Nations, or general commercial or marine Laws." Id. at 157. For other draft documents found among Wilson's papers (some of which were also in Wilson's hand), see id. at 134-37, 150-52, 152-57, 159-63. This draft authorized the national legislature to institute "in each State a Court of Admiralty for hearing and determining maritime Causes." Id. at 159. The draft may have been an effort by Wilson to overturn a loss he had sustained during the confederation period as counsel for General Benedict Arnold in a capture case involving the seizure of the British sloop, Active. While Wilson had won his case 
the limited power of Congress to particularize the cases the supreme tribunal could hear "involving the national peace and harmony" and the power in "the discretion of the legislature" to assign "[t]he whole or a part of" the judicial power of the United States to inferior federal courts.

A later Committee draft in Wilson's handwriting, with emendations by Rutledge, reflects the process of final adoption of the Committee draft. ${ }^{114}$ This later draft and the Committee report which emerged from it ${ }^{115}$ may be the two most important documents in ascertaining the intent of the framers relative to the judiciary. In its legislative articles, this draft authorized the Senate to appoint the judges of the Supreme Court and empowered Congress to constitute inferior national courts. ${ }^{116}$ The judiciary article, which began, "[t]he Judicial Power of the United States shall be vested in one Supreme (National) Court, and in such (other) [inferior] Courts as shall, from Time to Time, be constituted by the legislature of the United States." the judicial independence provisions relating to tenure and salary and continued, "The Jurisdiction of the Supreme (National) Court shall extend" to a list of particularized categories of cases resembling, but not identical to, the list ultimately adopted in article III. ${ }^{118}$ Significantly, the explicit reference authorizing Congress to assign such other cases to the Supreme Court as may involve the national peace and harmony, ${ }^{119}$ contained in the earlier Randolph-Rutledge draft, had disappeared entirely, the drafters having chosen the more mandatory phrase "shall extend" utilized in the amended Virginia Plan. ${ }^{120}$

before the congressional Court of Appeals which increased the prize money due his client from that awarded by a jury in a Pennsylvania admiralty court, the Pennsylvania court refused to comply with the larger award on the ground that state law forbade appeals of facts found by a jury. See Merry, supra note 3, at 64-65. This draft therefore may help shed some light on a later important, but cryptic, remark by Wilson suggesting that the Committee of Detail had intended the Supreme Court to review both law and fact and to entertain both civil and common law cases. See 2 Farrand, RECORDS, supra note 21, at 431; infra note 164 and accompanying text.

1142 Farrand, RECORDS, supra note 21 , at 172-73. A copy of the judicial article of this document is set forth in the Appendix.

${ }^{11 s}$ Id. at 186-87. The judicial article of the Committee of Detail draft is also set forth in full in the Appendix.

${ }^{116} I d$. at $168-69$.

117 Id. at 172 .

118 See id. At this stage of the proceedings, the draft judicial article did not include jurisdiction over cases arising under the Constitution or treaties of the United States, suits in which the United States was a party, or suits between citizens of the same state each claiming land under grants from different states. The grant of jurisdiction also then included authority to try impeachments of national officers.

128 See supra note 66 and accompanying text.

120 See supra note 113 and accompanying text. 
This draft also contained the first emergence of the "exceptions and regulations clause," although it will be recalled that Hamilton's unsubmitted plan had used a variation of the same phrase. ${ }^{121}$ Thus, this Wilson-Rutledge draft provided:

In Cases of Impeachment, (those) [cases] affecting Ambassadors (and) other public Ministers [\& Consuls], and those in which a State shall be (one of the) [a] Part(ies) [y], this Jurisdiction shall be original. In all the other Cases beforementioned, it shall be appellate, with such Exceptions and under such Regulations as the Legislature shall make. The Legislature may (distribute) [assign any part of] th(is)e Jurisdiction [above mentd., - except the Trial of the Executive - ], in the Manner and under the limitations which it shall think proper (among) [to] such (other) [inferior] Courts as it shall constitute from Time to Time. ${ }^{122}$

It is especially important that the exceptions and regulations clause made its initial appearance in a section of a draft constitution dealing with the distribution of federal judicial power, rather than in the clause delineating the scope of jurisdiction that would be exercised by the federal courts.

As it eventually emerged from the Committee of Detail, the draft article on the judiciary closely resembled the Wilson-Rutledge draft document. ${ }^{123}$ The only major change of substance, for present purposes, was the modification of the congressional power to establish inferior federal courts. The draft article reported by the Committee referred to "such inferior courts as shall, when necessary, from time to time, be constituted by the Legislature of the United States."124

In sum, a number of factors strongly suggest that the introduction of the exceptions and regulations clause was not intended to grant Congress any control over the scope of jurisdiction exercised by the Supreme Court. First, during the prior deliberations of the Convention, no proposal hinting at congressional control over the scope of jurisdiction of the national judiciary had been offered, and the Committee of Detail merely had been instructed to convert the results of those prior proceedings into a draft constitution.

Second, the juxtaposition of the Randolph-Rutledge draft with the

121 See supra note 49 and accompanying text.

1222 Farrand, RECORDS, supra note 21 , at 173 (as in original).

138 Compare id. at 172-73 (Wilson-Rutledge draft) with id. at 186-87 (Report of Committee of Detail draft).

${ }^{234}$ Id. at 186 (emphasis added). 
Wilson-Rutledge draft reflects the fact that the Committee's drafters clearly differentiated between congressional power over the scope of federal court jurisdiction and the allocation of that jurisdiction under the congressional authority over the structure of the federal judiciary. Thus, in the Randolph-Rutledge draft, ${ }^{125}$ the scope of federal jurisdiction was treated in separate sentences and paragraphs or blocks of clauses from the division of the appellate and original jurisdiction of the Supreme Court, and a congressional power was separately and explicitly granted over each. Similarly, the Randolph-Rutledge draft explicitly authorized Congress to vest " $t]$ he whole or a part of the jurisdiction"126 of the Supreme Court in such inferior federal courts as the Congress might create. The Wilson-Rutledge draft, ${ }^{127}$ the Committee report, ${ }^{128}$ and ultimately the final version of article III, preserved the separation into different sentences or paragraphs of provisions setting forth the scope of federal court jurisdiction from clauses dealing with the allocation of those powers within the federal judiciary. These later drafts omit, however, any explicit grant of congressional power over the scope of federal court jurisdiction. This change may be explainable as an attempt on the part of the Committee of Detail to adhere to the mandate and spirit of the prior Convention deliberations which contained no suggestion of a congressional power over the scope of federal jurisdiction. The Convention had already adopted the Madisonian compromise, ${ }^{129}$ however, and the power to make exceptions to the jurisdiction of the Supreme Court in favor of the exercise of such jurisdiction by the inferior federal courts would be consistent with that compromise, as would the explicit parallel statement in the Committee of Detail's draft report authorizing Congress to assign any part of the Supreme Court's jurisdiction to the inferior federal courts. ${ }^{130}$ This construction is further supported by the deliberate omission of the limitation that any inferior federal courts which Congress creates must serve "as original tribunals." This limitation was contained in the early Randolph-Rutledge draft ${ }^{131}$ but deleted from the Wilson-Rutledge draft, ${ }^{132}$ the Committee report, ${ }^{13 s}$ and, ultimately, article III. Thus, the members of the Committee may have envisioned the exercise by inferior federal courts

125 See supra note 111 and accompanying text.

128 See supra text accompanying note 111.

${ }^{127}$ See supra note 122 and accompanying text.

1282 Farrand, RECoRDS, supra note 21, at 186-87.

129 See supra note 58 and accompanying text.

1802 Farrand, RECORDS, supra note 21, at 186-87.

131 See supra note 111 and accompanying text.

132 See supra note 122 and accompanying text.

1382 Farrand, RECORDS, supra note 21, at 186-87. 
of appellate jurisdiction from state courts in order to assure the supremacy of the federal government in the enforcement of national laws and the resolution of matters of international or transstate concern. Indeed, Alexander Hamilton attributed precisely this intention to the Convention. ${ }^{134}$

So understood, the congressional power to make "exceptions" to the appellate jurisdiction of the Supreme Court, granted by the exceptions and regulations clause, was at most an authority to delete a class of cases from the jurisdiction of the Supreme Court in favor of exercise of power by an inferior federal court. This authority may also have been intended to include congressional power to reallocate the constitutionally structured appellate jurisdiction by authorizing the Supreme Court to exercise that jurisdiction in original form. Such authority had been explicitly included in the provisions of the Randolph-Rutledge draft $^{135}$ and disappeared from the document simultaneously with the emergence of the exceptions and regulations clause. The latter observation, of course, may suggest that Chief Justice Marshall later erred in his construction of article III when he assumed in Marbury $v$. Madison ${ }^{\mathbf{1 3 6}}$ that Congress could not enlarge the original jurisdiction of the Supreme Court. In line with this argument, the power to make "regulations" was the legislative authority to "organize" Supreme Court jurisdiction, as envisioned by the Randolph-Rutledge draft, and seems therefore to have subsumed the power to make rules of practice and procedure for the exercise of the constitutionally vested jurisdiction of the Court.

This construction belies the arguments of several historically oriented scholars who contend that the exceptions and regulations clause was only intended by the framers to authorize the safeguarding of the jury trial. According to these arguments, the clause modified the provisions authorizing Supreme Court appellate review "both as to Law and Fact," and its meaning was obscured by an inappropriate comma after

134 See supra notes $19 \& 22$ and accompanying text; see also THE FEDERALIST No. 83, at 556-57 (A. Hamilton) (J. Cooke ed. 1961).

135 See supra note 111 and accompanying text.

1s6 5 U.S. (1 Cranch) 137, 174-75 (1803). Chief Justice Marshall was not a delegate to the Philadelphia Convention, although he was a member of the Virginia state ratification convention. The interpretation in the text of the meaning of the exceptions and regulations clause is based on documents which were not contained in the Journal of the Convention, first published in 1819. In addition, since Madison's journals were not published until 1840 , four years after Marshall died, there is little way Marshall could have known of the potential error in his construction of the exceptions and regulations clause unless he had access to the private papers of George Mason, his political and economic rival from Virginia who had attended the Convention. 
"fact."137 These arguments are almost surely wrong, since the exceptions and regulations clause was introduced long before the provision relating to appellate review of law and fact was inserted into the document. ${ }^{138}$ The construction advanced here also challenges the generally assumed interpretation of the clause, supported by dicta in numerous cases, ${ }^{139}$ as authorizing Congress to omit absolutely various classes of cases otherwise within the judicial power of the United States from Supreme Court jurisdiction without reference to the exercise of such jurisdiction by inferior federal courts.

A third element suggesting that the so-called exceptions and regulations clause was not intended to grant Congress any control over the scope of jurisdiction exercised by the Supreme Court is that another potential construction exists for the word "Exceptions" in the clause that is consistent with Hamilton's original use of the phrase. It may be that the grant of congressional power was intended to refer only to a power to make "Regulations" for the appellate jurisdiction that the Constitution vested in the Supreme Court. Under this construction, the phrase, "with such Exceptions," should not be read as part of the same clause as that referring to regulations, but rather as a separate qualifying clause delimiting the scope of the appellate jurisdiction vested in the Supreme Court.

As it ultimately emerged from the Committee of.Style ${ }^{140}$ and as used in the final draft of the Constitution, the phrase, "with such Exceptions, and under such Regulations as the Congress shall make," contains an often overlooked comma after the word "Exceptions." Indeed, the Supreme Court has occasionally misquoted the clause by omitting

187 See Merry, supra note 3, at 68-69; see also Brant, supra note 3, at 6-8, 27-28. A better argument perhaps is that the comma after "Fact" was not inappropriate, but simply misplaced. Had the comma been placed after law- "both as to Law, and Fact with such Exceptions"-the exceptions and regulations clause might more plausibly have been read to apply only to Supreme Court jurisdiction over appellate review of facts.

138 The exceptions and regulations clause first appeared in Hamilton's June 18 draft and later in the Committee of Detail draft of the judicial article written during the last week in July or the first week in August. The clause dealing with appellate jurisdiction "both as to Law and Fact" was not added to the draft article until August 27. See infra notes 158 \& 164 and accompanying text.

180 See infra notes 349-54 and accompanying text.

140 The Committee of Style added the comma after "exceptions" to the draft sent to it from the Committee of Detail. Compare 2 Farrand, Records, supra note 21, at 576 (draft received from the Committee of Detail), with id. at 600-01 (draft as revised by the Committee of Style). Since the Committee of Style was given the limited charge "to revise the style of and arrange the articles agreed to by the House," id. at 547, it seems most likely that the addition of the comma was an attempt to clarify an underlying understanding of the exceptions and regulations clause. 
the comma. ${ }^{141}$ While the Committee of Detail draft did not contain this comma, its later insertion by the Committee of Style may only have clarified the original intended meaning of the clause. Understood in this respect, the phrase, "with such Exceptions," would have performed precisely the same function syntactically and been somewhat redundant of the phrase that begins the sentence in which it appears- "In all the other Cases beforementioned . . .," that is, both phrases would have served to set off original from appellate jurisdiction.

The "such Exceptions" contemplated under this construction were the classes of cases that the first sentence of the paragraph assigned to the original jurisdiction of the Supreme Court. Under this interpretation, the term "Exceptions" refers to a constitutionally defined omission contained in a separate sentence or clause from an otherwise generic category of Supreme Court jurisdiction.

The interpretation of the term "exceptions," set out above is in accordance with the use of the word in the Hamilton draft where it first appeared. ${ }^{142}$ The Hamilton plan was drafted for presentation to the Convention on June 18, after many of the major decisions on the outlines of the federal judiciary, including the Madisonian compromise on inferior federal courts, had already been debated and adopted. ${ }^{149}$ While there is no evidence that the Hamilton plan was ever presented to the Convention, it seems quite possible that the document was made available to members of the Committee of Detail. This scenario, while conjectural, might explain the emergence of the exceptions and regulations clause, which had no other referent in the state constitutions or the prior Convention deliberations.

After particularizing the jurisdiction of the Supreme Court in a manner similar to the style adopted by the Committee of Detail, the Hamilton plan contained the following limitations on the scope of that jurisdiction: "subject to such exceptions as are herein contained and to such regulations as the Legislature shall provide."144 The exceptions from the jurisdiction to which Hamilton referred were constitutional,

141 Significantly, in Ex parte McCardle, 74 U.S. (7 Wall.) 506, 513 (1869), the single most important decision interpreting the so-called exceptions and regulations clause, Chief Justice Chase, purporting to quote from the Constitution, omits this very important comma.

The author is highly indebted to his research assistant, Eleanor E. Lynn, for calling to his attention the potential linguistic significance of the comma in the exceptions and regulations clause. Her careful observation seems to have caught an important detail in the structure of article III that most of the commentators and the Supreme Court have missed.

142 See supra note 49 and accompanying text.

143 See supra notes 49,121-22 and accompanying text.

144 3 Farrand, RECORDS, supra note 21, at 626 (emphasis added). 
not legislative, in origin. More significantly, however, the exceptions envisioned in the Hamilton plan were deletions from the jurisdiction of the Supreme Court in favor of other federal tribunals provided for by the national constitution. Specifically, the "exceptions as are herein contained" seemed to refer to the "explicit exception from the jurisdiction of the Supreme Court over "controversies between the United States, and a particular State, or between two or more States" of those cases "such as relate to a claim of territory between the United States, and one or more States."145 The Hamilton plan provided that such cases were to be heard under a constitutionally established commission. The Senate was to choose one-third of the members of the commission, the affected state was to choose another third, and the remaining positions were to be filled by the judges of the Supreme Court. In short, under the Hamilton plan, "exceptions" were omissions from Supreme Court jurisdiction in favor of the exercise of the same jurisdiction by some other tribunal established under the authority of the federal constitution.

It is not unreasonable to assume that the phrase meant precisely the same thing in the Wilson-Rutledge draft and the final Committee report. First, as already noted, the provisions of the Randolph-Rutledge draft authorizing Congress to interchange the appellate and original jurisdiction of the Supreme Court and to "organize it" disappeared simultaneously with the emergence of the exceptions and regulations clause in the same position in the final Wilson-Rutledge draft. ${ }^{146}$ Second, in the Wilson-Rutledge draft and the final report of the Committee of Detail, the exceptions and regulations clause was immediately followed by a seemingly parallel clause explicitly authorizing Congress to assign the whole or any part of the jurisdiction of the Supreme Court to the inferior federal courts. Read together it appears that these parallel provisions authorized an exception to be made to the appellate jurisdiction of the Supreme Court when Congress chose to assign a portion of its powers to an inferior federal court. So construed, the exceptions and regulations clause authored by the Committee of Detail performed a function similar to that of the clause in the Hamilton plan.

So viewed, the framers never really drafted an exceptions and regulations clause as that term has come to be understood today. Rather, they included a clause in the final document authorizing the Congress to control by appropriate regulations the manner in which the appellate jurisdiction of the Supreme Court would be exercised. That clause

145 Id.

166 $2 \mathrm{id}$. at 186-87. See supra text accompanying note 111. 
gave Congress no power whatsoever over the scope of federal court jurisdiction. Like the other interpretation offered above, this construction of the Constitution compels the conclusion that the jurisdiction of the federal judiciary was mandatory, in apparent keeping with the prior deliberations of the Convention.

Finally, the Wilson-Rutledge draft and the Committee report retained the mandatory phrase "shall extend" when referring to the jurisdiction of the Supreme Court. This phrase had been included in the original Randolph plan and its various amendments during the early portion of the Convention deliberations. The Convention and the Committee apparently invoked "shall" in its mandatory sense rather than as future tense. The repeated consensus on the need for judicial independence and the fear of legislative encroachment on judicial powers strongly suggest that the framers did not intend to create any congressional power to determine the scope of jurisdiction of the federal judiciary. Indeed, no suggestion of any congressional power to determine jurisdiction was voiced in the earlier Convention deliberations. When a suggestion for congressional power over jurisdiction did briefly surface in the Randolph-Rutledge draft, the drafters carefully used the discretionary "may assign," as they also did when referring to congressional power to distribute judicial powers to inferior federal courts. Thus, the drafters fully understood the difference between the mandatory "shall" and the discretionary "may," and almost invariably used "shall" where a mandatory obligation was intended. ${ }^{147}$

147 Sections 1 of articles I, II, and III of the Constitution all begin with a command that the legislative, executive, or judicial powers of the national government "shall be vested" in the appropriate body. The word "shall" also occurs throughout the Constitution in contexts that clearly constitute mandatory commands. Examples include:

Provision

art. $1, \S 2$

art. I, $\S 3$

\section{Language}

The House of Representatives shall be composed of Members. . . and the Electors in each State shall have the Qualifications .... .

No Person shall be a Representative who shall not have attained to the Age ... and who shall not, when elected, be an Inhabitant of that State in which he shall be chosen.

Representatives and direct Taxes shall be apportioned ....

No Person shall be a Senator who shall not have attained to the Age .... and who shall not, when elected, be an Inhabitant of that State for which he shall be chosen. 
Separately, each of these observations suggests that the exceptions

art. I, § 4

art. I, § 5

art. I, § 6

art. I, § 7

art.I, § 8

art. I, $\S 9$

art. II, § 1

art. II, § 2
The Vice President ... shall be President of the Senate, but shall have no Vote .....

The Senate shall chuse their other Officers ....

The Senate shall have the sole Power to try all Impeachments ....

The Times, Places, and Manner of holding Elections for Senators and Representatives, shall be prescribed in each State ….

The Congress shall assemble at least once in every Year . . . .

Each House shall keep a Journal . . . . The Senators and Representatives shall receive a Compensation for their Services

All Bills for raising Revenue shall originate in the House of Representatives .....

The Congress shall have Power To lay and collect Taxes . . but all Duties, Imposts and Excises shall be uniform throughout the United States . . . .

The Privilege of the Writ of Habeas Corpus shall not be suspended . . . . No Bill of Attainder or ex post facto Law shall be passed.

No Money shall be drawn from the Treasury, but in Consequence of Appropriations made by Law; and a regular Statement and Account of the Receipts and Expenditures of all public Money shall be published....

The Electors shall meet in their respective States, and vote by Ballot for two Persons, of whom one at least shall not be an inhabitant of the same State with themselves.

In Case of the Removal of the President ... or Inability to discharge the Powers and Duties ... the Same shall devolve on the Vice President . . . .

The President shall . . . receive for his Services, a Compensation, which shall neither be encreased nor diminished during the Period for which he shall have been elected, and he shall not receive within that Period any other Emolument from the United States.

Before he enter on the Execution of his Office, he shall take the following Oath

The President shall be Commander in Chief of the Army and Navy.... 
and regulations clause drafted by the Committee of Detail was not intended to authorize any congressional control over the scope of jurisdic-

art. II, § 3

art. II, $\S 4$

art. IV, $\S 1$

art. IV, $\S 2$

art. IV, $\S 4$

art. VI
... he shall have Power to grant Reprieves and Pardons....

He shall . . give to the Congress Information of the State of the Union, and recommend ... such Measures as he shall judge necessary .... .

The President, Vice President and all Civil Officers of the United States, shall be removed from Office on Impeachment ....

Full Faith and Credit shall be given in each State....

The Citizens of each State shall be entitled to all Privileges and Immunities of Citizens in the several States.

The United States shall guarantee to every State in this Union a Republican Form of Government, and shall protect each of them against Invasion .... .

All Debts contracted and Engagements entered into .... shall be as valid against the United States under this Constitution, as under the Confederation.

This Constitution, and the Laws of the United States which shall be made in Pursuance thereof; and all Treaties made, or which shall be made, under the Authority of the United States, shall be the supreme Law of the Land; and the Judges in every State shall be bound thereby ....

(Emphasis added.)

On some occasions, as in the supremacy clause quoted immediately above, U.S. CoNST. art. VI, the framers also used the word "shall" to designate an event that would occur in the future. Usually, however, such references to the future occur in clauses suggesting a mandatory obligation elsewhere in the clause. See, e.g., U.S. CoNST. art. I, $\$ 2$ ("The actual Enumeration shall be made within three Years . . . in such Manner as they shall by Law direct"). Where the framers clearly contemplated substantial congressional or governmental discretion, they generally used the word "may." Examples include:

Provision

art. I, $\S 2$

art. $1, \S 4$

art. I, §5
Language

Representatives ... shall be apportioned among the several States which may be included within this Union ....

but the Congress may at any time by Law make or alter such Regulations....

but a smaller Number may adjourn from day to day, and may be authorized to compel the Attendance of absent Members .... under such Penalties as each House may provide.

Each House may determine the Rules of its Proceedings.... 
tion of the entire federal judicial establishment. Taken together, they

art. I 7

art. I, $\S 8$

art. I 9

art. I, § 10

art. II, $\S 1$

art. II, $\S 2$

art. II, § 3

art. IV, § 1

art. IV, § 3

art. V excepting such Parts as may in their Judgment require Secrecy .... .

but the Senate may propose or concur with Amendments as on other Bills.

To provide for organizing, arming and disciplining, the Militia, and for governing such Part of them as may be employed in the Service of the United States .....

but a Tax or duty may be imposed on such Importation .....

The Privilege of the Writ of Habeas Corpus shall not be suspended, unless when in Cases of Rebellion or Invasion the public Safety may require it.

No State shall . . . lay any Imposts or Duties on Imports or Exports, except what may be absolutely necessary for executing its inspection Laws . . . .

The Congress may determine the Time of chusing the Electors . . . .

and the Congress may by Law provide for the Case of Removal, Death, Resignation or Inability, both of the President and Vice President . . . .

he may require the Opinion . . . of the principal Officer in each of the executive Departments .... .

the Congress may by Law vest the Appointment of such inferior Officers, as they think proper, in the President alone, in the Courts of Law, or in the Heads of Departments.

he may, on extraordinary Occasions, convene both Houses . . . and in Case of Disagreement ... he may adjourn them

And the Congress may by general Laws prescribe the Manner in which such Acts, Records and Proceedings shall be proved, and the Effect thereof.

New States may be admitted by the Congress into this Union. . . .

as the one or the other Mode of Ratification may be proposed by the Congress

....

\section{(Emphasis added.)}

The structure of article III, both as proposed by the Committee of Detail and as finally adopted, also reflects this consistent usage of "shall" and "may." Section 1 provides that the "judicial Power of the United States, shall be vested" in the federal courts but, reflecting the Madisonian compromise vesting discretion in Congress over the creation of lower federal tribunals, goes on to include in the federal judiciary "such inferior Courts as the Congress may from time to time ordain and establish." The next sentence, stating that the term of judicial office is to continue during good behaviour, and 
build an overwhelming case for that conclusion, particularly in light of the almost total lack of evidence suggesting any contrary conclusion. ${ }^{148}$ The case presented here should establish with reasonable certainty the intent on the part of the members of the Committee of Detail to continue the mandatory federal court jurisdiction envisioned in the amended Randolph plan and to reject congressional control over the scope of jurisdiction of the federal judiciary.

guaranteeing the judges against diminution in their salaries, also invokes the mandatory "shall." In section 2, the language describing the scope of the jurisdiction of the federal courts is again mandatory: "The judicial Power shall extend . . . ." Similarly, the allocation of jurisdiction of the Supreme Court between original and appellate forms, contained in the second paragraph of section 2 of article III uses the mandatory "shall." Finally, the guarantee of jury trial in criminal cases other than impeachments, contained in the last paragraph of section 2 of article III, and the definition of the crime of treason, contained in section 3 of article III, both employ the mandatory "shall."

Arguably, one of the most glaring departures from the framers' consistent use of the word "shall" in its mandatory sense is the so-called exceptions and regulations clause of section 2, of article III, providing for Supreme Court appellate jurisdiction "with such Exceptions, and under such Regulations as Congress shall make." (Emphasis added.) While the term "shall" in this clause conventionally has been thought only to connote a future tense, the word may have been used in an imperative sense. According to the thesis of this Article, Congress was obligated to invest the entirety of the specified appellate jurisdiction in the Supreme Court or, at least, in inferior federal courts. Since article III did not fully describe or structure the size or procedures of the Supreme Court or require the creation of inferior federal courts, it was imperative for Congress to enact regulations to carry this constitutional mandate into effect.

148 The only real suggestions during the Philadelphia Convention of any legislative control over the scope of federal court jurisdiction occurred in the Randolph-Rutledge draft, which contained a clause-which was apparently rejected-authorizing congressional delineation of Supreme Court jurisdiction, and in an August 27 debate, when the delegates rejected by a vote of two states to six a proposal which would have expressly authorized the Congress to direct the manner in which the judicial power was exercised. See infra note 158 and accompanying text. While it might be argued that these clauses were rejected because they were redundant, that conclusion seems farfetched. First, such an argument requires one to assume that the framers intended to accomplish by the vague and opaque language of the exceptions and regulations clause precisely what they could have explicitly accomplished through these clear and direct proposals which they rejected. Second, this argument ignores the etiology of the exceptions and regulations clause in the Hamilton plan and in the Randolph-Rutledge draft in provisions dealing with the distribution of federal court jurisdiction, rather than the scope of that authority. Third, the recorded split vote on the rejected August 27 proposal suggests that the vote was on the merits of legislative control of jurisdiction, rather than on the less important question of semantic redundancy. See infra note 177. Finally, not one speech was recorded at any time during the Convention favoring the principle of legislative control over the scope of jurisdiction of the federal judiciary. In contrast, numerous statements have been pointed out suggesting strong support, and possibly even consensus, for assuring an independent judiciary and the desire to prevent legislative encroachments on the judicial power. Thus, to view the rejection of the Randolph-Rutledge draft and the August 27 proposal as evidence of support of the framers for congressional control over the scope of federal court jurisdiction would inaccurately read these statements wholly out of context. 
5. Refining the Judiciary Article: The Goncluding Debates and the Committee of Style

The Committee of Detail reported its draft to the floor of the Convention on August 6. Thereafter, until the end of August, debate focused upon this document. The Convention approved without debate that portion of the draft authorizing the Congress to constitute inferior federal courts. ${ }^{149}$ A proposal to authorize each house of Congress, as well as the Executive, "to require the opinions of the supreme Judicial Court upon important questions of law, and upon solemn occasions," i.e., to authorize the Court to issue advisory opinions, was referred to the Committee, where it later died a quiet death. ${ }^{150}$ Also referred to the Committee was a proposal by Pinckney to extend the jurisdiction of the Supreme Court to "all controversies between the U.S. and an individual State, or the U.S. and the Citizens of an individual State."151

On August 27, a very important debate on the judiciary article occurred. At the urging of Doctor Johnson of Connecticut, the Convention extended the judicial power to cases "in law and equity" (over Read's objection "to vesting these powers in the same Court"). ${ }^{162}$ Dickinson of Delaware proposed making the judges removable by the Executive upon joint application by each branch of Congress, similar to what was done in Great Britain. This proposal provoked a flurry of resistance. Gouverneur Morris, Rutledge, Wilson, and Randolph all arose to defend the autonomy and independence of federal judges. Rutledge noted, "[i]f the supreme Court is to judge between the U.S. and particular States, this alone is an insuperable objection to the motion."15s Randolph feared "weakening too much the independence of the Judges," and Wilson said, "[t]he Judges would be in a bad situation if made to depend on every gust of faction which might prevail in the two branches of our Govt." 154 The strength of delegate commitment to judicial independence was evident, since the proposal lost by a vote of one state (Connecticut) to seven, with three state delegations absent. ${ }^{185}$

After the Convention overwhelmingly defeated several proposals to prohibit judicial salaries from being increased by the legislature during

1492 Farrand, ReCoRDs, supra note 21, at 313, 315.

${ }^{280}$ Id. at $334,341-42$.

182 Id. at 342.

162 Id. at 428 .

I6s Id.

106 Id. at 429.

165 Id. 
a judge's term of office, ${ }^{168}$ the delegates turned to the scope of federal court jurisdiction. They first agreed to expand federal jurisdiction to controversies in which the United States was a party, apparently picking up on Pinckney's earlier proposal. ${ }^{167}$ Thereafter, according to Madison's notes, a vital debate ensued that ultimately shaped the final structure of article III. Given the critical importance of this debate, Madison's note on the deliberations are set forth in full:

Docr. Johnson moved to insert the words "this Constitution and the" before the word "laws"

Mr. Madison doubted whether it was not going too far to extend the jurisdiction of the Court generally to cases arising Under the Constitution, \& whether it ought not to be limited to cases of a Judiciary Nature. The right of expounding the Constitution in cases not of this nature ought not to be given to that Department.

The motion of Docr. Johnson was agreed to nem: con: it being generally supposed that the jurisdiction given was constructively limited to cases of a Judiciary nature -

On motion of Mr. Rutlidge, the words "passed by the Legislature" were struck out, and after the words "U.S" were inserted nem. con: the words "and treaties made or which shall be made under their authority" - conformably to a preceding amendment in another place.

The clause "in cases of impeachment", was postponed.

Mr. Govr. Morris wished to know what was meant by the words "In all the cases before mentioned it (jurisdiction) shall be appellate with such exceptions\&c," whether it extended to matters of fact as well as law-and to cases of Common law as well as Civil law.

Mr. Wilson. The Committee he believed meant facts as well as law \& Common as well as Civil law.'The jurisdiction of the federal Court of Appeals had he said been so construed.

Mr. Dickinson moved to add after the word "appellate" the words "both as to law \& fact which was agreed to nem: con:

Mr. Madison \& Mr. Govr. Morris moved to strike out the beginning of the $3 \mathrm{~d}$ sect. "The jurisdiction of the su-

158 Id. at $423,429-30$. proposal).

187 Id. at 423, 430; see supra note 151 and accompanying text (Pinckney 
preme Court" \& to insert the words "the Judicial power" which was agreed to nem: con:

The following motion was disagreed to, to wit to insert "In all the other cases before mentioned the Judicial power shall be exercised in such manner as the Legislature shall direct" [Del. Virga ay N. H. Con. P. M. S. C. G no] [Ayes-2; noes-6.]

On a question for striking out the last sentence of sect. 3. "The Legislature may assign \&c-."

N. H. ay-Ct ay. $\mathrm{Pa}$ ay. Del-ay-Md ay-Vaay-S-G. ay-Geo. ay. [Ayes-8; noes-o.]

$\mathrm{Mr}$. Sherman moved to insert after the words "between Citizens of different States" the words, "between citizens of the same State claiming lands under grants of different States"-according to the provision in the 9th. art: of the Confederation-which was agreed to nem: con:

Adjourned $^{188}$

This colloquy is important to an understanding of the jurisdiction established under article III in a number of respects. First, implementing the suggestions of judicial review made earlier during debate on the proposed Council of Revision, the framers separately and expressly vested in the federal judiciary the power to hear cases arising under the Constitution. It is difficult to comprehend what cases Doctor Johnson had in mind if he did not contemplate the exercise of judicial review. Thus, this colloquy renders much of the debate over the legitimacy of judicial review, at least insofar as it concerns review of the constitutionality of state actions, largely irrelevant from an historical perspective.

Second, Madison's efforts to limit the power of judicial review to "cases of a Judiciary Nature" were apparently constructively accepted by the Convention. This event lends historical support to the interpretation of a constitutional proscription against the federal judiciary rendering advisory opinions, enforced since Hayburn's Case, ${ }^{150}$ and validates the Court's refusal of President Washington's request for such advice. $\stackrel{160}{\sim}$ It further lends support to the constitutional dimensions of the standing, ripeness, and mootness doctrines enforced by the national

1582 Farrand, RECORDS, supra note 21, at 430-32.

2892 U.S. (2 Dall.) 408 (1792).

160 Correspondence of the Justices, Letter from Chief Justice John Jay and Associate Justices to President George Washington (August 8, 1793) (discussed in G. GuNTHER, supra note 4, at 1607-11); see also HART \& WECHSLER, supra note 3, at 64-66; L. Tribe, American Constitutional Law § 3-10, at 56-57 (1978). 


\section{courts since Marbury v. Madison. ${ }^{\mathbf{1 6 1}}$}

Third, the delegates to the Convention again manifested their discomfort with assigning the trial of impeachments to the federal judiciary, possibly because of the potential that such jurisdiction might come to interfere with judicial independence. ${ }^{\mathbf{1 6 2}}$

Fourth, the debate represents the origin of the interjected clause authorizing Supreme Court appellate review "both as to law \& fact," which would prove so controversial during the later ratification debates. Dickinson moved to add this clause to clarify what Wilson claimed was. the underlying meaning of the phrase in the draft providing that "[i]n all the cases before mentioned it [Supreme Court Jurisdiction] shall be appellate with such exceptions and regulations as the Legislature shall make."16s

In order to limit the asserted scope of congressional power over Supreme Court jurisdiction, some scholars have seized upon this debate to suggest that the exceptions and regulations clause was solely intended to modify and delimit the provisions authorizing review of fact, in order to preserve jury trials. ${ }^{104}$ This argument seems wholly incorrect, however, in light of the historical context of this debate. The exceptions and regulations clause was added to the draft document by the Committee of Detail almost a month before the insertion, during this August 27 debate, of the clause authorizing Supreme Court review of fact. It is therefore highly unlikely that the two clauses were intended by the framers to be related. While certain scholars emphasize that Wilson's remarks about review of fact were in response to questions about the meaning of a quoted phrase which included the word "exceptions," this argument seems to take Morris's question wholly out of context. From Madison's notes, it appears much more likely that Morris was asking what the members of the Committee of Detail meant by "appellate" jurisdiction, not what they meant by "exceptions." That

1615 U.S. (1 Cranch) 137 (1803).

162 See 2 Farrand, RecoRDs, supra note 21, at 423, 424, 430, 431. Later Gouverneur Morris argued, "[a] conclusive reason for making the Senate instead of the Supreme Court the Judge of impeachments, was that the latter was to try the President after the trial of the impeachment." Id. at 500.

163 See id. at 431.

104 See supra note 137 and accompanying text. During the waning days of the Convention, Madison may have considered changes in the language authorizing appellate review by the Supreme Court both as to law and fact to more precisely reflect the intention of the Convention. In a memorandum dated September 7, 1787, he proposed to change the word "Fact" to "Equity." 4 Farrand, RECORDS, supra note 21, at 60-61. This proposal, however, was never submitted to the Convention. Had it been adopted, it might have avoided some of the heated and contentious debates over civil jury trial which later occurred in the ratification conventions and the public debate. See infra notes 185-86, 198-219 and accompanying text. 
would explain why the framers inserted the phrase "both as to law \& fact" immediately after the word "appellate" and further why the comma following the phrase was deliberate, not misplaced, as these scholars have argued. ${ }^{165}$ The argument of these scholars also fails for two other reasons. Wilson's response referred not only to review of facts, but also to review of "Common as well as Civil law." If the exceptions clause was solely intended to capture Wilson's response, it would seem to allow exceptions to be made from the scope of legal questions cognizable under the Supreme Court's appellate jurisdiction-precisely the result these scholars resist. In addition, there is not one word in this debate about protecting the right to trial by jury or about authorizing Congress to delimit Supreme Court appellate intrusions on this respected institution. To accept such an intent on this record is to build an original understanding out of thin air. Arguments for original intent must rest on much firmer footing.

The fifth and most essential respect in which the August 27 debate is important is the fact that the delegates explicitly rejected, by a vote of six states to two, a clause providing that "the Judicial power shall be exercised in such manner as the Legislature shall direct."168 A clearer rejection of congressional authority over judicial powers is hard to imagine. While the context of this proposal does not precisely indicate whether it was intended to grant congressional power over the scope of federal court jurisdiction or, rather, only over its allocation, the former by far would seem to be the more plausible interpretation, since another clause already existed in the draft of the Committee of Detail expressly authorizing the Congress to reassign the jurisdiction of the Supreme Court to such inferior federal courts as it might create. That clause was later struck from the document during the August 27 debate. The decisive rejection of the former proposal to invest Congress with power over the jurisdiction of the federal courts indicates that the framers, or at least a majority of the state delegations, did not intend to create any extensive congressional power over the jurisdiction of the federal judiciary. This vote also renders the two limited readings of the so-called exceptions and regulations clause offered above far more plausible than the contrary conventional explanation suggesting substantial congressional discretion over the appellate jurisdiction of the Supreme Court. It is highly doubtful that a Convention which rejected an explicit statement authorizing congressional power over the scope of jurisdiction of the federal judiciary would silently countenance such a result 
by more opaque and ambiguous language.

Finally, the Convention made two simultaneous changes in the structure of the judiciary article relating to the distribution, as opposed to scope, of federal judicial powers. ${ }^{167}$ Without debate, they changed the beginning of the paragraph containing the particularization of federal jurisdiction from a description of "[t]he jurisdiction of the supreme

167 A draft document which clearly reflects these changes is set forth in I THE DocumentaRy History of the Ratification of The Constitution 280-81 (M. Jensen ed. 1976) [hereinafter cited as DOcumentaRy History]. This document was apparently prepared from George Washington's printed copy of the Committee of Detail draft, with amendments and changes in the hand of Washington and William Johnson, Secretary of the Convention, reflecting the changes voted by the Convention in its deliberations between August 7 and September 10.

In an otherwise excellent article, Professor Sager has rejected the thesis that the exceptions clause was designed to authorize Congress to distribute the judicial power of the United States between the Supreme Court and inferior federal courts, focusing his argument principally upon the fact that the Committee of Detail draft contained a separate clause authorizing Congress to assign jurisdiction to the lower federal courts. Sager argues, "[i]f the exceptions clause had been understood simply to authorize Congress to shift jurisdiction from the Supreme Court to lower courts, this language would have been superfluous. Indeed, because the assignment language was discretionary, the assignment clause itself was contrary to the view that Congress must vest jurisdiction in lower courts if Congress withholds jurisdiction from the Supreme Court." Sager, supra note 3 , at 35 n.51; see also id. at 31 n.36.

This argument has two important analytical flaws. First, it totally ignores the overall structure and phrasing of the Committee of Detail draft. The draft's recitation of the cases cognizable in a federal court was, as then drafted, only a description of "the jurisdiction of the supreme court." The separate clause authorizing the assignment of Supreme Court jurisdiction to the inferior federal courts was necessary to delimit the scope of powers which constitutionally could be assigned to such courts, and the exceptions clause was required separately to authorize Congress to carve exceptions out of the Supreme Court's constitutionally assigned jurisdiction. The two clauses were parallel and complementary, not redundant or superfluous. Indeed, the parallel nature of the two clauses was evidenced by the parallel changes made by the Convention on August 27-simultaneously changing "jurisdiction of the supreme court" to "the judicial power" and deleting the separate clause authorizing Congress to assign the jurisdiction of the Supreme Court to the inferior federal courts, which was rendered superfluous by the first change.

Second, Professor Sager's propensity to read the separate clauses of the judiciary article in isolation, reflected in his flawed analysis of the Committee of Detail draft, also mars his argument that the draft assignment clause was discretionary and therefore inconsistent with a mandatory view of federal court jurisdiction. He totally ignores the fact that the Committee draft required that the judicial power of the United States "shall extend" to the Supreme Court and whatever federal courts, if any, Congress chose to create. While there was no constitutional obligation to create inferior courts, in light of the Madisonian compromise, or to assign such courts any particular portion of the judicial power (thereby explaining the discretionary phrasing of the assignment clause), there was a mandatorily phrased constitutional obligation to assure that the whole of the categories of cases cognizable in federal courts could be heard somewhere in the federal judicial establishment either in original or appellate form. Thus, Professor Sager's analysis of this point seemingly fails because it represents the same kind of single-sentence analytical approach criticized in the introductory section of this Article. See infra note 177. 
Court" to a description of "the Judicial power." The latter phrase had already been used in the first paragraph of the document to describe the powers which "shall be vested in one Supreme Court, and in such inferior Courts as shall, when necessary, from time to time be constituted by the Legislature of the United States."168 This change, therefore, rendered the described jurisdiction applicable to all federal courts, not just the Supreme Court. With this simple, but very important, change, the explicit grant of power allowing Congress to assign to inferior courts the whole or any part of the jurisdiction of the Supreme Court became redundant and was therefore unanimously stricken from the document. It is clear that the members still intended to allow Congress to assign such powers to the inferior federal courts.

With the clause deleted, however, it might be objected that no explicit power remained in the judiciary article by which Congress could accomplish that result. That objection is answered by the surviving exceptions and regulations clause which immediately preceded the deleted phrase. Once the described jurisdiction was applicable to the judicial power of the United States as a whole, rather than to the jurisdiction of the Supreme Court alone, "exceptions" from the appellate jurisdiction of the Supreme Court could be made only by vesting jurisdiction over the omitted class of cases in an inferior federal court. Only in this way could "the Judicial power of the United States," described in the judiciary article, remain "vested in one Supreme Court, and in such inferior Courts" as Congress may establish, as mandated by section 1 of the article. Thus, the framers must have intended the exceptions and regulations clause to be read in conjunction and conformity with the mandatory first paragraph of the judiciary article, rather than in isolation, as it has most often been construed since the Convention. Otherwise, the deletion of the power to assign jurisdiction to the inferior federal courts would have left Congress without any explicit grant of authority in the judiciary article to so allocate the judicial power of the United States. These two seemingly unimportant technical changes, therefore, yield on close analysis further important support for the conclusion that "exceptions" contemplated under the exceptions and regulations clause were at most assignments of portions of the judicial power from the Supreme Court to inferior federal courts and, possibly, the rearrangement of the classes of cases heard in original, as opposed to appellate, form by the Court. So read, these changes add further evidence to compel a mandatory reading of the requirement that "the Judicial power of the United States shall be vested" in the federal judi- 
ciary. The congressional power countenanced by the Convention was merely structural and distributive; it did not reach the scope of the categories of cases cognizable in the federal judiciary as a whole.

After this important August 27 debate, most of the changes in the draft article on the judiciary made by the delegates, and later by the Committee of Style, were technical and syntactical, rather than substantive. For example, the Committee of Style rephrased the reference in the first paragraph to "such Inferior Courts as shall, when necessary, from time to time, be constituted by the Legislature of the United States" to read "such inferior courts as the Congress may from time to time ordain and establish"- a seemingly unimportant change of phrase, capturing the same idea. ${ }^{169}$ The change of the word "shall" in the Convention's working draft to "may" in the Committee of Style draft also reflects the framers' continuing sensitivity to the careful use of the mandatory "shall."170 The Committee also attempted to clarify the

168 Id. at 600 . The amendment deleted one of the few uses of the word "shall" in a context which was clearly intended to be discretionary. This attention to language by the Committee of Style continues the trend by the drafters at the Convention to careful, selective use of the word "shall" where a mandatory duty was intended. Noting this change, Professor Goebel, however, argues:

The effect of eliminating the words "as shall, when necessary" was to deprive Congress of power to decide upon the need for inferior courts and so to give full imperative effect to the declaration that "The judicial power ... shall be vested in one supreme court, and in such inferior courts ...." That the Committee intended to convey the sense of an imperative is apparent from the choice of the most forceful words in the contemporary constitutional vocabulary-"ordain and establish"-to direct what Congress was to do.

J. GoEBEL, supra note 3, at 247. Thus, according to Goebel, "The discretion left to Congress was the authority to settle the institutional pattern at the lower level of judicial administration and to arrange how the jurisdiction conferred by section 2 of Article III was there to be disposed." Id. at 246. Goebel's claim seems insupportable insofar as it suggests the tacit adoption by the Committee of a mandatory obligation by Congress to establish inferior federal courts. Such a conclusion is contradicted by the almost unquestioned adherence of the Convention to the Madisonian compromise and the limited charge of the Committee of Style "to revise the style of and arrange the articles agreed to by the House," 2 Farrand, ReCords, supra note 21, at 547. Professor Bator has dismissed Goebel's argument as "uncharacteristically thinly supported and unpersuasive," HART \& WECHSLER, supra note 3, at $13 \mathrm{n} .46$, and two other commentators have dismissed the thesis, noting "it remains to be seen that the words 'ordain and establish" are significantly more imperative than the phrasing of the original draft." Redish \& Woods, supra note 3 , at 61; see also Sager, supra note 3, at 34 n.47.

${ }_{170}$ In addition to the above changes, on August 28 the phrasing of the reference to the Supreme Court's appellate jurisdiction was altered to take account of the change in the description of the judicial powers that rendered the referent of an "it" ambiguous. 2 Farrand, RECORDS, supra note 21 , at $434,437-38$. At the same time, Congress was authorized to direct the place of trial for crimes committed outside of any state, and the delegates, at the urgings of Pinckney, Rutledge, and Gouverneur Morris, voted to prevent the suspension of the writ of habeas corpus except when required by public safety in time of rebellion or invasion and to approve the limitation on the reach of judgments 
meaning of the exceptions and regulations clause by inserting a comma after the word "Exceptions."171

Thus, as reported by the Committee of Style on September 10, the judiciary article closely resembled in major points the one reported by the Committee of Detail and ultimately included in article III. ${ }^{\mathbf{1 7 2}}$

In the closing days of the Convention, few changes were made in the draft article offered by the Committee of Style. Since the phrase "both in law and equity" appeared in both section 1 and the first paragraph of section 2 of article III, as reported by the Committee of Style, the delegates struck the superfluous clause in section 1 and deleted the word "both" in section $2 .{ }^{173}$ The issue of civil jury trial, which would later play a major role in the ratification debates, briefly surfaced late in the Convention when Pinckney and Gerry unsuccessfully proposed that "a trial by jury shall be preserved as usual in civil cases."174 While no one opposed the institution of the civil jury in cases at law, the motion was defeated because Gorham and King pointed out that "[ $t]$ he constitution of Juries is different in different States and the trial itself is

on impeachments. $I d$. at 434,438 . While the suspension of habeas corpus clause ultimately found its way into section 9 of article $I$ of the Constitution as a limitation on congressional power, it is significant that it was first raised in conjunction with a discussion of the judiciary article. The desire to limit congressional power over the habeas corpus remedy further supports the view that the framers sought to limit, not create, congressional power over the scope of federal court authority. It also suggests that the writ of habeas corpus envisioned was a writ issued by a federal court. It might be argued that the perceived necessity to expressly limit congressional power to suspend the Great Writ implied a latent legislative power over the jurisdiction of the federal courts. This argument, however, would misstate the effect of a suspension of the writ by confusing jurisdiction with the availability of a remedy. When the writ of habeas corpus is lawfully suspended, it is not the jurisdiction of the court that is suspended, but rather the actual enforcement of the remedial writ issued by the court. See, e.g., Ex parte Milligan, 71 U.S. (4 Wall.) 2, 130-31 (1866); cf. Eisentrager v. Forrestal, 174 F.2d 961 (D.C. Cir. 1949), rev'd on other grounds sub nom. Johnson v. Eisentrager, 339 U.S. 763 (1950); Ex parte Zimmerman, 132 F.2d 442, 444-46 (9th Cir. 1942) (both cases suggesting that neither Congress nor the executive has any power to deprive the courts of jurisdiction to entertain applications for writs of habeas corpus). Thus, while the distinction is a fine one, the suspension clause should properly be viewed as a substantive limitation on congressional legislative power, rather than as a protection of federal court jurisdiction. This distinction may help explain why the Committee of Style chose to include the clause in section 9 of article $\mathrm{I}$, dealing with limitations on congressional power, rather than in the judiciary article as originally proposed.

A proposal to allow the Supreme Court to adjudicate the claims of the United States or individual states to the western territories was tabled on August 30 and ultimately defeated. 2 Farrand, RECORDS, supra note 21 , at 458-59, 465-66. These proposals were part of a package of amendments, some of which were accepted by the Convention, designed to preserve state autonomy from the exercise of federal legislative and judicial power. $I d$. at 457-69.

171 See supra notes 140-42 and accompanying text.

1722 Farrand, RECORDS, supra note 21 , at 575-76.

178 Id. at 621 .

174 Id. at 628. 
usual in different cases in different States."175 Therefore, Pinckney maintained that "such a clause in the Constitution would be pregnant with embarrassments." 178 Evidently, the framers, while not opposed to the institution of the civil jury trial at law, were more concerned with assuring uniformity of federal judicial practice. Nevertheless, the lack of such a protection in the final document gave birth to harsh and particularly troublesome attacks on the document by antifederalists during the ratification debates. With this and several other last-minute matters resolved, the Convention signed and reported out the Constitution in its final form on September 17.

From the foregoing discussion, it is clear that substantial evidence from the records of the Convention supports a construction of the judicial article of the Constitution which mandatorily vests the whole of the judicial power of the United States in the federal judicial establishment. The extent of the congressional power over the judiciary envisioned by the framers was the power to structure and organize the Supreme Court and the inferior federal courts, and to distribute the constitutionally mandated jurisdiction among these national courts. There is little evidence suggesting any strong sentiment in favor of broader congressional control; the repeated statements by various delegates stressing the desire to protect the judiciary from legislative encroachment and the votes of the Convention favoring judicial independence seem to preclude any such intention. Indeed, the clear defeat on August 27 of the one proposal offered to the whole Convention that called for some measure of legislative control over the jurisdiction of the federal courts, and the rejection by the Committee of Detail of a similar proposal in the Randolph-Rutledge draft, would seem to refute any intention on the part of the Convention to create anything other than a mandatory, constitutionally established jurisdiction for the federal courts. ${ }^{177}$

${ }^{176} I d$.

176 Id.

177 Professor Sager has argued that too much stress should not be placed on the August 27 vote, which he partially confuses with the proposal to grant limited legislative control over Supreme Court jurisdiction set forth in the Randolph-Rutledge draft and rejected by the Committee of Detail. See Sager, supra note 3, at 49-50 n.95. By contrast, Attorney General William French Smith relies heavily on this vote in his letter opinion questioning the constitutionality of certain recent jurisdictional curtailment proposals, concluding that "[t]he Convention thus rejected a clear statement of plenary congressional power over the Court's appellate jurisdiction." Letter from Attorney General William French Smith to Senator Strom Thurmond, Chairman, Senate Comm. on Judiciary 6-7 (May 6, 1982) (copy on file with University of Pennsylvania Law Review).

Sager, building upon the work of other commentators, argues that the proposal to give Congress power over the appellate jurisdiction of the Supreme Court was "nothing more than an aesthetic alteration." Sager, supra note 3, at 49-50 n.95 (citing HART \& 


\section{The Ratification Debates: Deffending the Document}

The ratification of the Constitution through state conventions, as

WeChSLER, supra note 3, at 12 n.46; Ratner, Power, supra note 3, at 164 n.34). Like the authors of HART \& WECHSLER, Sager believes, without apparent support, that the rejected proposal was part of a largely rhetorical change, which also included the striking of the clause authorizing the Congress to assign Supreme Court jurisdiction to the lower federal courts and the change in the language of the Committee of Detail draft from "jurisdiction of the Supreme Court" to the "Judicial Power." Thus, most of the attention devoted by Sager, the authors of HART \& WECHSLER, and Ratner to this vote actually focuses upon the proposed clause authorizing Congress to assign Supreme Court jurisdiction to the inferior federal courts. Sager concludes this somewhat confused argument by stating, "[t]he argument that the power to 'assign' the Court's jurisdiction entails the power to deprive the Court of jurisdiction is further undercut by the fact that the assignment provision in the Committee of Detail's final draft was accompanied by the exceptions clause, . . . which itself apparently authorizes Congress to curtail the Court's jurisdiction." Sager, supra note 3, at 49-50. Oddly, at another point in his article, Sager appears to take an inconsistent position, arguing that the Committee of Detail's rejection of the congressional power over Supreme Court jurisdiction proposed in the Randolph-Rutledge draft "strongly suggests that the Committee intended the Court to derive jurisdiction from the Constitution itself." Id. at 24 n.18.

Sager's argument, like that in HART \& WECHSLER and that of Ratner, is somewhat flawed because it gives inadequate separate attention to the rejection of the August 27 proposal explicitly to vest Congress with plenary power over Supreme Court jurisdiction. This proposal does not appear merely to have been a minor part of a larger package of rhetorical changes, as Sager and others seem to suggest. While the evidence on this point is not conclusive, based in part on Madison's uncharacteristically skimpy notes of the August 27 debate, the fact that the proposal for a grant of legislative power over the Court's jurisdiction was overwhelmingly rejected, while the other semantic changes proposed during the debate were unanimously accepted, suggests that the problem with the August 27 proposal was substantive, not rhetorical. Furthermore, Sager's analytical confusion of the provisions of the rejected assignment clause with the proposal to vest Congress with plenary power over Supreme Court jurisdiction and his ready willingness to assume that the exceptions clause authorized the curtailment of federal court jurisdiction, rather than the distribution of the judicial power of the United States, reflects the tendency of many commentators and courts, criticized above, to read clauses in article III out of context and in isolation. See supra note 167.

With all of the confusion manifest in his treatment of the historical record, Professor Sager nevertheless comes to a conclusion that closely approximates the original understanding of the framers, suggesting that the Constitution neither empowers Congress to enact court-stripping statutes to overturn unpopular constitutional decisions nor disables the Court from declaring such legislation unconstitutional. Sager, supra note 3, at 89. He nevertheless arrives at this conclusion only partially as a result of a confused historical analysis, relying additionally on important constitutional policy considerations of preserving the independence of the federal judiciary and the essential functions of the Supreme Court.

Raoul Berger has published a vituperative attack on what he considers Professor Sager's "polemic" challenging congressional authority over federal court jurisdiction. See Berger, Insulation of Judicial Usurpation: A Comment on Lawrence Sager's "Court-Stripping" Polemic, 44 OHIo ST. L.J. 611 (1983). Berger has not in any way attacked the accuracy of Sager's history of the Philadelphia Convention or ratification debates. Rather his attack focuses principally on Sager's alleged cavalier treatment of the case law interpreting article III. Since Sager's argument is in part grounded on the original purposes of article III, one would think that a careful exploration of the historical record would have been appropriate from Berger whose work focuses primarily on 
prescribed by the document, produced a very different focus and type of

ferreting out the "legislative record" of the history surrounding various constitutional provisions. Berger's almost total failure to cite to Farrand's collection of records of debates at the Philadelphia convention or Elliot's compilation of the ratification debate materials, therefore, is very difficult to explain. Berger has repeatedly argued that the appropriate issue for constitutional inquiry is the original intent of the framers since "[i]f the Court may substitute its own meaning for that of the Framers it may, as Story cautioned, rewrite the Constitution without limit." R. BERGER, supra note 12, at 370 . Berger has also insisted that prior case law inconsistent with the original understanding of the framers should be ignored since "the Constitution itself, stripped of judicial incrustations, [is] the index of constitutional law." Id. at 297. Thus, Berger's failure seriously and exhaustively to consider the primary historical record of the Philadelphia and the ratification debates seems totally inconsistent with his often stated legal philosophy. This failure is even more surprising from a scholar who has probed these historical sources in his earlier scholarship and therefore should be intimately familiar with these primary historical materials. See, e.g., R. BERGER, supra note 3.

Even in those few instances in which Berger does refer to the historical record of the Philadelphia Convention and the ratification debates, his treatment of the historical data is inaccurate or misleading.

For example, in his attack on Sager's position, Berger fails to note the deletion by the Committee of Detail of the Randolph-Rutledge draft proposal to authorize limited congressional power over the scope of federal jurisdiction, and the only notice Berger apparently takes of the overwhelming August 27 defeat of an explicit proposal to give Congress authority to control the jurisdiction of the federal courts is a brief reference to the fact that Sager made a confused reference to it. Berger, supra, at 622 n.106. While Sager's reference is indeed confused, Berger's failure to clarify or discuss the matter is inexplicable. Rather, Berger relies, in part, on statements Hamilton made defending the limited nature of federal jurisdiction to suggest that Congress should be able to assure that the jurisdiction is kept within appropriate boundaries. Id. at $616,627,628$. These statements, however, had nothing to do with congressional power. Instead they constituted part of Hamilton's defense of the limited jurisdiction constitutionally committed to the federal courts. As this Article demonstrates, when Hamilton directly addressed the meaning of the article, he concluded that the framers meant to assure constitutionally that all cases within the judicial power of the United States received either their original or final decision by an independent article III tribunal-a position very similar to that adopted by Sager and precisely the conclusion Berger is attacking. See supra note 19 and accompanying text; infra notes 299-323 and accompanying text. Berger ignores this portion of Hamilton's writings, just as he completely fails to note the manner in which the term "exceptions" was used in the Hamilton draft of the exceptions and regulations clause.

Similarly, in one of Berger's only references to the ratification debates, he approvingly cites the comments of William Grayson of Virginia, a leading anti-federalist opponent of the adoption of article III who also voted against the adoption of the Judiciary Act of 1789 while in the Senate. The context of Berger's reference to Grayson seems to suggest that Grayson was one of "[t]he states' rights advocates at the Constitutional Convention." Berger, supra, at 616. Grayson, however, did not attend the Philadelphia Convention and as a vociferous opponent of article III clearly cannot be taken as an authoritative reflection of the framers' intent.

Berger also relies extensively on the allegation that the 1789 Judiciary Act did not confer complete jurisdiction over all cases enumerated as within the judicial power of the United States, without noting that there is significant evidence in the legislative debates over the Act that some of the supporters of the Act believed both that they were constitutionally obligated to commit all of the judicial power of the United States to federal court cognizance and that they had done so. Compare id. at 614, 632-33 with infra note 357 and accompanying text. Even if the First Congress had intended to limit the constitutionally vested jurisdiction of the federal courts, such evidence should not be 
debate from that generated at the Philadelphia Convention. The members of the Philadelphia Convention had met throughout the summer in closed session and had devoted much of their time to discussions and debate of general structural principles governing the new Union. It was not until the Committee of Detail reported its draft on August 6, nearly two and one-half months after the start of the Convention, that the framers even began debating the actual language of a draft Constitution. This slow, deliberate process was no doubt aided by the secrecy surrounding their proceedings, which left the delegates free from direct political pressures and criticisms.

In contrast, the ratification process was wide-open and well publicized. Much of the political debate over the adoption of the draft document took place in the press and in printed broadsides. ${ }^{178}$ The speeches of candidates seeking seats in state ratification conventions were widely reported, as were the debates in many of the state conventions. Thus, the ratification process was less a deliberative procedure and more a political forum in which prominent state politicians could advance their own interests and hinder those of their opponents. ${ }^{170}$ Furthermore, the

considered persuasive under Berger's view of the importance of original understanding. If that intent was inconsistent with the meaning of article III derived from the Philadelphia Convention and the ratification debates, the First Congress presumably had no more authority to revise the Constitution than does the Supreme Court.

At one point in Berger's discussion, he protests Sager's reliance on original understanding arguments to support what Berger regards as judicial activist positions. He states that "resort to legislative history must be evenhanded." Id. at 615. Berger has that point precisely right, but he cannot very well attack others for ignoring or manipulating legal history or original understanding arguments when he appears to have done precisely the same thing. An unsupportable diatribe aimed at what Berger regards as a polemic is no substitute for solid historical scholarship. Berger simply cannot say, as he does, that "[t]he legislative history lends [Sager] cold comfort," $i d$. at 632, when he has hardly probed the historical data and has certainly failed to examine that record in the level of detail offered here or by Professor Sager. As this Article and Sager's efforts indicate, the "legislative record" of the true framers, the federalist supporters of the Constitution at the Philadelphia Convention and during the ratification debates, is plainly inconsistent with Berger's position. Resort to original understanding must indeed be evenhanded!

178 See generally I, II DocumentaRy History, supra note 167; Ford, PaMPHLETS, supra note 21; EsSaYs ON THE Constitution OF THE UNITED STATES (P. Ford ed. 1892) [hereinafter cited as Ford, Essays].

179 Far from constituting a scholarly, dispassionate study of the work of the Philadelphia Convention, the ratification debates were really a political conflict in which both sides operated in substantial ignorance of the proceedings that led to the adoption of the various provisions of the document. As one of the leading historians of the ratification process put it, "[t]he Constitution was debated, for the most part, in ignorance of the proceedings of the Constitutional Convention." I DocumENTARY HisTORY, supra note 167 , at 26 . Thus, certain political diatribes against the document, often containing inaccurate characterizations, were widely circulated. The objections of George Mason, Luther Martin, Elbridge Gerry, Robert Yates, and John Lansing, Jr. probably received the widest publication. Id. 
ratification process focused on the language of a single document, the draft Constitution. This helped steer much of the debate away from wide-ranging inquiries into general principles of appropriate government for the Union, ${ }^{180}$ and toward a more focused, often politicized debate over particular clauses in the draft document.

In this atmosphere the general issue of legislative control over the jurisdiction of the national judiciary received almost no direct attention. Rather, when the issue arose at all, it did so only in passing, during debates over other facets of the proposed judiciary article. Thus, one finds almost no direct debate over the meaning of the requirement that "the judicial Power of the United States, shall be vested in one supreme Court, and in such inferior Courts as the Congress may from time to time ordain and establish" or the exceptions and regulations clause. Even the debate over the congressional power to create inferior federal courts focused mostly on the desirability of such courts, paying almost no attention to the desirability or breadth of the legislative power in question.

Furthermore, when supporters or opponents of the Constitution referred to the jurisdiction of the federal courts they often seemed to assume that the Constitution itself invested those courts with the jurisdiction prescribed in the first paragraph of section 2 of article III. For example, Luther Martin criticized the judiciary article because it removed from the state courts the jurisdiction to enforce national revenue laws and "confined" it to the courts of the United States. ${ }^{181}$ Pendleton of Virginia referred to the jurisdiction "given" to the Supreme Court by the Constitution. ${ }^{182}$ Randolph ${ }^{183}$ stated that the jurisdiction conferred upon federal courts under the document "extends to all cases in law and equity arising under the Constitution."184 In contrast, there were very few direct suggestions of complete congressional power to delimit the classes of cases which could be heard in federal courts, especially

180 The principal exception to this generalization was The Federalist, discussed infra notes 299-323 and accompanying text.

1823 Farrand, RECORDS, supra note 21, at 204.

1823 The Debates in the Several State Conventions on the Adoption of the Federal Constirution 549 (J. Elliot ed. 1901) [hereinafter cited as Elliot, Debates].

${ }^{183}$ Randolph played a curiously inconsistent role by proposing the Virginia Plan, refusing to sign the Constitution in part because of the breadth and vagueness of the judiciary article, and ultimately grudgingly supporting the document and the judiciary article in the Virginia Convention. In a letter Randolph wrote to the speaker of the Virginia House of Delegates dated October 10,1787, just after the close of the Philadelphia Convention, he explained his reasons for refusing to sign the Constitution and listed its deficiencies "[i]n limiting and defining the judicial power." 3 Farrand, RECORDS, supra note 21 , at 127.

1843 Elliot, DeBates, supra note 182, at 572 (emphasis added). 
the Supreme Court.

The debate over the judiciary during the ratification process focused principally, indeed almost exclusively, on the objections raised by the antifederalists. These objections were similar from state to state and included a number of closely related points, to which this Article now turns.

\section{A. Antifederalist Arguments Against Adoption of Article III}

First, and foremost, the antifederalists repeatedly argued that the Constitution not only inadequately protected the right to jury trial, ${ }^{185}$ but in fact positively infringed upon it in civil cases by providing for appellate review both as to law and fact. For example, during the long and very heated debates over the judiciary during the Virginia convention, Patrick Henry argued that "[n]othing can be more clear and incontestable. This will, in its operation, destroy the trial by jury. The verdict of an impartial jury will be reversed by judges unacquainted with the circumstances." 186

Second, the antifederalists expressed a number of interrelated but distinct concerns about the breadth of the potential federal judiciary and its potential to annihilate the state courts and unsettle legal expectations created under state law. Specifically, they directly attacked the breadth of federal court jurisdiction established in the constitutional draft, singling out for special attack the diversity jurisdiction and cases in which states may be parties, especially cases involving citizens of other states. ${ }^{187}$ Some, like Grayson of Virginia, also feared the breadth of federal question jurisdiction, arguing that it was "of stupendous magnitude" and that it was "so vaguely and indefinitely expressed" that it was "impossible for human nature to trace its extent."188

Additionally, the antifederalists were concerned about the relationship which would exist between the newly created federal judiciary and

183 See, e.g., 1 id. at 381-82 (letter of Luther Martin); 2 id. at 550 (concerns expressed by committee in Maryland convention); 3 id. at 528 (comments of George Mason); 3 id. at 540-42 (comments of Patrick Henry); 4 id. at 143 (comments of J. M'Dowall); id. at 151 (comments of Bloodworth).

1883 id. at 540.

187 See, e.g., id. at 523, 526 (comments of George Mason); id. at 566 (comments of Grayson); II Documentary History, supra note 167, at 308-09; Ford, PamPHLETS, supra note 21, at 306-08 (Letters of the Federal Farmer [Richard Henry Lee of Virginia] No. III); Ford, Essays, supra note 178, at 66-67 (Letters of Agrippa No. V), 96-97 (Letters of Agrippa, No. XIII).

18B 3 Elliot, DeBATES, supra note 182, at 565.

Grayson also led antifederalist grumbling about the propriety of joining admiralty, equity, criminal, and common law jurisdiction in one over-powerful national court. Id. at 564 ; see infra note 227. 
the already extant state courts. Some antifederalists, like Luther Martin, based much of their argument on the assumption that the exercise of the judicial power of the United States was exclusively confined to the federal courts" 189 and might therefore "swallow up the state jurisdictions."180 Such antifederalists argued that the ratification of the Constitution would leave no residual judicial business for the local courts; they feared that the national courts would soon "utterly annihilate . . . state courts."191

Closely related was the antifederalist attack on the congressional power to create inferior federal courts, the antifederalists arguing that the state courts were more than adequate to entertain such cases in the first instance. ${ }^{192}$ Thus, others, like Grayson of Virginia, while conceding concurrent federal and state jurisdiction; feared that the federal courts would necessarily come into conflict with the local judiciaries. He said, " $[t]$ he interference of the federal judiciary and the state courts will involve the most serious and even ludicrous consequences. Both courts are to act on the same persons and things, and cannot possibly avoid interference."193

In attacking the breadth of the federal judicial establishment, the antifederalists also pointed out the expense, both to the government and to the parties, which the new federal courts would create. Focusing upon the great inconveniences, delays, and costs in traveling to and producing witnesses at a far distant court, especially if located in the national capitol, the antifederalists argued that the existing state judicial machinery was more convenient and less costly and that the proposed national judiciary would merely increase expense and unnecessarily multiply appeals. ${ }^{194}$ This argument was buttressed by the potential need to produce witnesses again in the Supreme Court if that court was, indeed, to review facts as well as law. ${ }^{195}$

\footnotetext{
1891 Elliot, Debates, supra note 182, at 551.

1002 id. at 551.

191 Id. at 528 (George Mason).

192 Spencer of North Carolina, for example, said,

There does not appear to me to be any kind of necessity that the federal court should have jurisdiction in the body of the country. I am ready to give up that, in the cases expressly enumerated, an appellate jurisdiction (except in one or two instances) might be given . . . . But in the body of a state, the jurisdiction of the courts in that state might extend to carrying into execution the laws of Congress. It must be unnecessary for the federal courts to do it, and would create trouble and expense which might be avoided.
} 
On occasion, antifederalists also candidly expressed fears that the retroactive nature of the proposed national judicial establishment would result in injustice and personal inconvenience by unsettling legal expectations created under state law. Especially strong was the fear that such retroactivity might affect Revolutionary War debts and unsettle land titles, particularly the titles involving Lord Fairfax's former estate in the Northern Neck of Virginia. ${ }^{196}$ As later events would prove, the latter concern was particularly well founded. ${ }^{197}$

\section{B. Federalist Arguments Favoring Adoption of Article III}

\section{Jury Trial Issues}

Federalist responses to the antifederalist concerns reflect the political nature of much of the ratification debates. One finds supporters of the Constitution, sometimes even members of the Philadelphia Convention, using the language of the document in ways unanticipated at the Philadelphia Convention in order to respond to critics of ratification. ${ }^{198}$ The ratification debate over the protection of jury trial in civil cases most severely tested the political acumen of the federalists and provided the springboard for most of the important comments on congressional power over the judiciary. If the antifederalists could prove that the document attacked as basic an institution as civil jury trial, they could successfully taint the entire enterprise and doom it to failure. As noted

George Mason); 4 id. at 143 (comments of J. M'Dowall).

ios See, e.g., 3 id. at 579-81 (comments of Patrick Henry and George Nicholas); see also infra notes 281 \& 284. Henry of Virginia felt that such retroactivity of federal jurisdiction would be "as odious as an ex post facto law." 3 Elliot, DeBates, supra note 182 , at 542 .

In Virginia, where the dispute over title to the Northern Neck had raged since 1782 when the Commonwealth had purported to confiscate the title of Lord Fairfax to the area, this concern was particularly acute. George Mason, a delegate to the Philadelphia Convention who had refused to sign the Constitution, argued against adoption of the document in the Virginia ratification convention in part because he was "personally endangered as an inhabitant of the Northern Neck." 3 id. at 528-29. He argued:

As Lord Fairfax's title was indisputably good, and as treaties are to be the supreme law of the land, will not his representatives be able to recover all in the federal court? How will gentlemen like to pay an additional tax on lands in the Northern Neck? This the operation of this system will compel them to do. They now are subject to the same tax as other citizens are; and if the quitrents be recovered in the federal court, they are doubly taxed. . . . How will a poor man, who is injured or dispossessed unjustly, get a remedy? Is he to go to the federal court, seven or eight hundred miles? He might as well give his claim up. He may grumble, but, finding no relief, he will be contented.

Id. at 529.

107 See infra note 276.

198 See infra notes 203-07 and accompanying text. 
above, the antifederalist argument turned on what Randolph called the "unfortunate" clause authorizing appellate jurisdiction both as to law and fact, ${ }^{199}$ a phrase Pendleton wished "had been buried in oblivion."200 In the Virginia convention antifederalists led by Patrick Henry and George Mason enlarged their attack by arguing that there was no way for Congress to protect the civil jury trial under the proposed document. After explaining that the constitutionally vested appellate jurisdiction of the Supreme Court included review of facts under the Constitution, Patrick Henry referred to the exceptions and regulations clause and argued,

Congress cannot, by any act of theirs, alter this jurisdiction as established. It appears to me that no law of Congress can alter or arrange it. It is subject to be regulated, but is it subject to be abolished? If Congress alter this part, they will repeal the Constitution. Does it give them power to repeal itself? What is meant by such words in common parlance? If you are obliged to do certain business, you are to do it under such modifications as were originally designed. . . . When Congress, by virtue of this sweeping clause, will organize these courts, they cannot depart from the Constitution; and their laws in opposition to the Constitution would be void. ${ }^{201}$

Henry went on to suggest that if Congress sought to limit the appellate review of the Supreme Court over facts, "the federal judges, if they spoke the sentiments of independent men, would declare their prohibition nugatory and void."202 Thus, for Patrick Henry, the jurisdiction of the federal courts was mandatorily set forth by the Constitution, not only as to the classes of cases comprising the judicial power of the United States, but also as to the scope of review. To Henry, the congressional power seemed merely distributive.

Had such strong arguments for mandatory federal court jurisdiction been made by federalists who had supported the Constitution at the Philadelphia Convention, they would probably have been accepted and applauded. That they came from antifederalists and in the context of an effort to prove that the proposed Constitution infringed upon the right to civil jury trial called for a different sort of response from the federalist supporters of the document. The federalists argued that the review of fact language of article III stemmed from the desire to pre-

1903 Elliot, Debates, supra note 182, at 572.

$200 \mathrm{Id}$. at 519.

201 Id. at $540-41$.

202 Id. at 541. 
serve the traditional broader review powers of an appellate court in equity and admiralty cases, and not from any antipathy to civil jury trial in common law cases. ${ }^{208}$ This argument, while no doubt historically accurate, failed to satisfy the antifederalists, who pointed out first, that the language of the clause also reached Supreme Court review of facts in common law cases, and second, that the document expressly protected the institution of jury trial in criminal cases, ${ }^{204}$ but was silent on jury trial for civil causes. In part, the federalists responded to these concerns by correctly arguing that protection of civil jury trial was omitted because of the wide disparity in civil jury practice among the states. $^{205}$ James Wilson explained in the Pennsylvania convention:

By the Constitution of the different states, it will be found that no particular mode of trial by jury could be discovered that would suit them all. The manner of summoning jurors, their qualifications, of whom they should consist, and the course of their proceedings, are all different in the different states; and I presume it will be allowed a good general principle, that, in carrying into effect the laws of the general government by the judicial department, it will be proper to make the regulations as agreeable to the habits and wishes of the particular states as possible; and it is easily discovered that it would have been impracticable, by any general regulation, to give satisfaction to all. We must have thwarted the custom of eleven or twelve to have accommodated any one. Why do this when there was no danger to be apprehended from the omission? We could not go into a particular detail of the manner that would have suited each state. ${ }^{208}$

203 See, e.g., id. at 519 (comments of Pendleton); id. at 557-60 (comments of John Marshall); 4 id. at 162-63 (comments of Maclaine).

sot See, e.g., 4 id. at 143 (comments of Bloodworth of North Carolina); id. at 154 (comments of Spencer of North Carolina).

${ }^{203}$ See, e.g., 2 id. at 488 (comments of James Wilson); 4 id. at 144 (comments of Spaight of North Carolina); id. at 1.44-45 (comments of Iredell of North Carolina); see also supra notes $175-77$ and accompanying text.

${ }^{20} 2$ Elliot, DeBaTES, supra note 182, at 488. Wilson did, however, seek to justify the Supreme Court's power to review facts on appeal, noting:

We find it essentially necessary from the ample experience we have had in the courts of admiralty with regard to captures. Those gentlemen who, during the late war, had their vessels retaken, know well what a poor chance they would have had when those vessels were taken in their states and tried by juries, and in what a situation they would have been if the Court of Appeals had not been possessed of authority to reconsider and set aside the verdicts of those juries. Attempts were made by some of the states to destroy this power; but it has been confirmed in every instance.

$2 \mathrm{id}$. at 493-94. Wilson's reference to the experience under the confederation Court of 
The federalist response, as Wilson's comments suggest, also focused on the asserted congressional power to protect jury trials under the exceptions and regulations clause. Indeed, most of the important comments on the issue of congressional power over federal court powers emerged in the context of the concern over jury trials, particularly in the Virginia convention where the judiciary article was most thoroughly and heatedly debated. Since it is demonstrably clear that the exceptions and regulations clause was not drafted at the Philadelphia Convention to modify the review of law and fact language in article III, ${ }^{207}$ comments such as Wilson's constitute post-Convention revisionism of the meaning and purpose of that clause. When made by federalists, like John Marshall, who had not attended the Philadelphia Convention and who apparently had no access to the then unpublished notes and documents from the Convention, such revisionism is understandable. Some of the comments came, however, from delegates like Wilson, Madison, and Randolph who had attended and even played major roles in the drafting of the judicial article. For them such revisionism is best explained by the political context in which the statements were made. Successful ratification of the document was more important than historical accuracy or intellectual consistency, and these framers seized upon all plausible constructions of clauses in the document which met their need to respond to antifederalist concerns. ${ }^{208}$

While revisionist, some of the federalist comments suggesting congressional power to limit Supreme Court appellate jurisdiction over facts were generally carefully couched and limited. It is almost as if the speaker sensed the potential which such a concession might have for encroachment on the powers of the federal courts, and sought to limit the breadth of their claims. Madison, for example, seemed to confine the congressional power to making regulations as to review of facts,

Appeals may have been a pointed attack on his unsuccessful venture in litigating the case involving the capture of the sloop Active. See supra note 113. Thus, for Wilson, more so than for other federalists, the power of the Supreme Court to review fact, as well as law, may have been seen as essential for assuring federal supremacy. Such review power would frustrate state efforts to block the enforcement of federal law by finding facts contrary to the vindication of the federal right. Elsewhere Wilson argued that many of the cases cognizable in federal courts should not be tried to a jury since they depended on the law of nations, marine law, or "the general law of mercantile countries," all areas where uniformity was sought. 2 Elliot, DEBATES, supra note 182, at $516-17$.

${ }^{202}$ See supra notes 137-39 \& 164 and accompanying text.

208 Nevertheless, the comments of these framers represent the strongest support for the view that the exceptions and regulations clause should be read as solely modifying the clause authorizing Supreme Court appellate review "both as to law and fact." Oddly, the scholars who have advanced this view have almost wholly ignored these debates. See supra note 137. 
saying nothing about issues of law:

But if gentlemen should contend that appeals, as to fact, can be extended to jury cases, I contend that, by the word regulations, it is in the power of Congress to prevent it, or prescribe such a mode as will secure the privilege of jury trial. They may make a regulation to prevent such appeals entirely; or they may remand the fact, or send it to an inferior contiguous court, to be tried; or otherwise preserve that ancient and important trial. ${ }^{209}$

Alexander Hanson, a member of the Maryland ratification convention, published remarks which defended the provisions for review of fact, noting, "in regard to appeals, it is very material to remark, that congress is to make such regulations and exceptions, as upon mature deliberation, it shall think proper. And indeed, before such regulations and exceptions shall be made, the manner of appeal will not be ascertained."210 Hanson, therefore, seemingly understood the congressional power as one of prescribing the mode of review, but not necessarily the class of cases which could be appealed. He added, "Now every man, who would establish over his cause a jurisdiction in a federal court, must shew, that such cause comes under the description of the constitution."211 Yet he nowhere suggested any additional requirement of congressional authorization for the exercise of jurisdiction.

Some of the responses to the antifederalist civil jury trial arguments were not, however, as carefully couched. Randolph, whose fears of the breadth of federal judicial power had caused him to withhold support for the final document in Philadelphia, ${ }^{212}$ disagreed with Henry's suggestion that Congress had no power to delimit the power of the Supreme Court to review facts. He argued that broad congressional power did indeed exist:

It was insisted on by [Henry] that these words [the exceptions and regulations clause] could not extend to law and fact, and that they could not separate the fact from the law.

2093 Elliot, Debates, supra note 182, at 534.

210 Ford, PAMPhLETS, supra note 21 , at 238.

Iredell of North Carolina explained that the Convention could "fix upon no permanent rule [for civil jury trials] that was not liable to great objections and difficulties" and the delegates therefore "thought it better to leave all such regulations to the legislature itself, conceiving there could be no real danger, in this case, from a body composed of our own representatives, who could have no temptation to undermine this excellent mode of trial in civil cases . . . " 4 Elliot, Debates, supra note 182, at 166.

2114 Elliot, Debates, supra note 182, at 240.

212 See supra note 183. 
This construction is irrational; for, if they cannot separate the law from the fact, and if the exceptions are prevented from applying to law and fact, these words have no force at all. It would be proper here to refer to any thing that could be understood in the federal court. They may except generally both as to law and fact, or they may except as to law only, or fact only. ${ }^{213}$

Taken out of context, this statement was probably the baldest, most sweeping assertion of congressional power over federal court jurisdiction to appear anywhere in the course of the adoption of the Constitution. ${ }^{214}$ It is, however, ambiguous. Since Randolph was only referring to appellate review by the Supreme Court, it is somewhat unclear whether the envisioned exceptions "as to law" from Supreme Court jurisdiction were absolute withdrawals of classes of cases from the cognizance of the federal courts or, rather, merely exceptions from Supreme Court jurisdiction in favor of distributing the judicial power of the United States to inferior federal courts.

There may, however, be good reason to believe that Randolph did in fact deliberately intend to ignore the distributive purposes of the clause in favor of engrafting onto it a more far-reaching congressional power. Randolph's suggestion that under Henry's construction the clause had no force whatsoever seems wholly to ignore the distributive purposes of the clause intended by the framers. Having refused to sign the Constitution, in part because he felt that the judicial power needed further "limiting and defining,"21s Randolph ultimately, but reluctantly, joined the federalist cause. He may. nevertheless have sought to accomplish his purpose of limiting the judiciary by imposing an unintended meaning on the exceptions and regulations clause. This inter-

ma 3 Elliot, DeBATES, supra note 182, at 572.

214 See also infra notes 217-19 and accompanying text. One is tempted to speculate that Randolph may have deliberately attempted to engraft onto the document an unintended congressional power over the scope of federal court jurisdiction in the hopes that Congress might later ameliorate the jurisdictional problems that concerned him. Whatever Randolph's intent, however, the evidence suggests that his position gained very few converts during the ratification debates. For example, the proposals to curtail the jurisdiction of the national courts were almost invariably offered as constitutional amendments, neither partisans nor opponents of the document suggesting that the same result could be as easily accomplished by legislative enactment. See infra notes 277-84 and accompanying text.

In a published "Letter of a Citizen of New Haven," dated December 4, 1788, Roger Sherman, however, did venture the suggestion that "[ $t]$ he judiciary department is perhaps the most difficult to be precisely limited by the constitution, but congress have full power to regulate it by law, and it may be found necessary to vary the regulations at different times as circumstances may differ." Ford, Essays, supra note 178, at 235.

216 See supra note 183. 
pretation would be consistent with the congressional power over federal jurisdiction contained in the draft Randolph wrote for the Committee of Detail, but which the Committee had rejected. ${ }^{216}$ Randolph's draft had at least made mandatory the federal court jurisdiction over cases arising under national laws and impeachments of federal officers. His misrepresentation of the exceptions and regulations clause in the Virginia Convention, however, made all Supreme Court appellate jurisdiction subject to congressional control. While one cannot lightly dismiss this interpretation of the exceptions and regulations clause offered by as important a personage as Edmond Randolph, there are sound historical reasons to suspect that it may not accurately reflect the true intent of the framers who drafted and ardently supported the Constitution.

More troublesome to this Article's thesis are John Marshall's comments during the Virginia ratification convention. It will be recalled that Marshall, a strong federalist and supporter of the Constitution, had not attended the Philadelphia Convention and, therefore, was left to respond to antifederalist attacks from the naked text of the document, unaided by any notes or personal recollections of the Convention's deliberations. Marshall answered Henry's attack on the absence of congressional power to protect civil jury trial, as follows:

The honorable gentleman says that no law of Congress can make any exception to the federal appellate jurisdiction of facts as well as law. He has frequently spoken of technical terms, and the meaning of them. What is the meaning of the term exception? Does it not mean an alteration and diminution? Congress is empowered to make exceptions to the appellate jurisdiction, as to law and fact, of the Supreme Court. These exceptions certainly go as far as the legislature may think proper for the interest and liberty of the people. Who can understand this word, exception, to extend to one case as well as the other? I am persuaded that a reconsideration of this case will convince the gentleman that he was mistaken. This may go to the cure of the mischief apprehended. Gentlemen must be satisfied that this power will not be so much abused as they have said.217

Marshall evidently construed the exceptions and regulations power to modify the phrase "both as to law and fact," which is a demonstrable historical error. ${ }^{218}$ It is also evident that Marshall was contending for a

216 See supra notes 111-12 and accompanying text.

2173 Elliot, DeBaTES, supra note 134, at 559-60.

218 See supra notes 137-39 \& 164 and accompanying text. 
sweeping congressional power to make alterations and diminutions in the jurisdiction of the federal courts.

It is difficult to understand how Marshall, who as Chief Justice was to become so instrumental in establishing a strong federal judiciary as a bulwark of constitutional government and federal supremacy, ${ }^{210}$ could support and argue for so sweeping a congressional control over the national judiciary. Part of the answer may lie in the context of his statements, which were a response to antifederalist arguments which he believed must imperatively be laid to rest. He may therefore have overstated his case to pound the last nail into the coffin of the antifederalists. We might also conjecture that he was misled by Randolph, who had attended the Philadelphia Convention. Whatever the reason, Marshall indirectly advanced one of the stronger statements in support of congressional control over the jurisdiction of the national courts.

\section{Concerns over the Scope of the Judicial Power of the United States}

While the civil jury trial issue produced extensive comment on the congressional power to delimit Supreme Court review of facts, the antifederalist attacks on the breadth of the judicial power of the United States prescribed by the Constitution and on the costs, inconvenience, and potential threat to state courts posed by article III produced almost no suggestions by federalists that Congress could delimit the sphere of federal court jurisdiction. ${ }^{220}$ The startling absence of such suggestions,

219 See, e.g., Gibbons v. Ogden, 22 U.S. (9 Wheat.) 1 (1824); Cohens v. Virginia, 19 U.S. (6 Wheat.) 264 (1821); McCulloch v. Maryland, 17 U.S. (4 Wheat.) 316 (1819); Marbury v. Madison, 5 U.S. (1 Cranch) 137 (1803). This history also may help explain the tortured reasoning process that Chief Justice Marshall later adopted when cases touching upon issues of congressional power over the federal courts reached the Court for review. See infra notes 349-52 and accompanying text.

${ }_{220}$ Madison did offer a somewhat interesting comment in attempting to defend the grant of diversity jurisdiction to the federal courts. He said:

Let me observe that, so far as the judicial power may extend to controversies between citizens of different states, and so far as it gives them power to correct, by another trial, a verdict obtained by local prejudices, it is favorable to those states which carry on commerce. There are a number of commercial states which carry on trade for other states. Should the states in debt to them make unjust regulations, the justice that would be obtained by the creditors might be merely imaginary and nominal. It might be either entirely denied, or partially granted. This is no imaginary evil. Before the war, New York was to a great amount a creditor of Connecticut. While it depended on the laws and regulations of Connecticut, she might withhold payment. If I be not misinformed, there were reasons to complain. These illiberal regulations and causes of complaint obstruct commerce. So far as this power may be exercised, Virginia will be benefited by it. It appears to me, from the most correct view, that by the word regulations, authority is given them to provide against the inconveniences; and so far as it is exceptionable, they can remedy it. 
of course, suggests that a broad congressional power over the breadth of federal court jurisdiction was not widely assumed by federalist supporters of the document. Rather, the federalists generally met antifederalist attacks on the scope of federal court jurisdiction by stressing the necessity of conferring the cases enumerated as the judicial power of the United States on national courts staffed with judges who were not dependent for appointment, salary, or continuance in office on the legislature of any state. The need for a neutral forum and neutral laws shaped the justifications offered by many federalists for committing many of the eleven classes of cases comprising the judicial power of the United States to the federal courts.

In regard to the breadth of the class of cases given to the federal courts, Pendleton of Virginia argued that all eleven classes of controversies set forth as part of the judicial power of the United States were "of general and not local concern." 221 Madison argued that "it is so necessary and expedient that the judicial power should correspond with the legislative, that it has not been objected to,"222 adding that the subjects of federal court jurisdiction were "mostly of great importance, and indispensably necessary."223

In more specific terms, federalists expounded on the desirability of federal tribunals in a broad variety of contexts. Yet none of them, even when offering only a lukewarm defense of a particular type of jurisdiction, ever suggested the existence of congressional power to curtail the federal court authority. Many federalists supported the scope of federal court jurisdiction as necessary to guarantee to supremacy of federal law. In the North Carolina convention William Davie, a member of the Philadelphia Convention, stressed the importance of national courts in assuring adherence to federal law, arguing: "Every member will

3 Elliot, Debates, supra note 182, at 534-35. While Madison's comments are somewhat ambiguous, it appears that he may have viewed the congressional power to make regulations governing the exercise of Supreme Court jurisdiction merely to refer to the substantive laws which Congress might pass, rather than regulations prescribing the means of execution of the judicial power of the United States or limiting the scope or operation of those powers. So read, the exceptions and regulations clause would be viewed merely as a command for federal courts to apply congressionally enacted substantive law, just as the supremacy clause of article VI requires state courts to apply federal law. Under such a construction, the clause would not operate to authorize Congress to control or limit the jurisdiction of the federal courts in any manner. This construction would have important contrary implications for any argument that there was a constitutional dimension to the Rules of Decision Act, ch. 20, \& 34, 1 Stat. 92 (1789) (current version at 28 U.S.C. $§ 1652$ (1976)), or Erie R.R. v. Tompkins, 304 U.S. 64 (1938).
2213 Elliot, Debates, supra note 182 , at 518.
122 Id. at 532.
${ }^{223}$ Id. at 534. 
agree that the positive regulations ought to be carried into execution, and that the negative restrictions ought not to be disregarded or violated. Without a judiciary, the injunctions of the Constitution may be disobeyed, and the positive regulations neglected or contravened."224 Citing the limitations on state government contained in section 10 of article I, he stated:

These restrictions ought to supersede the laws of particular states. With respect to the prohibitory provision-that no duty or impost shall be laid by any particular state-which is so highly in favor of us and the other non-importing states, the importing states might make laws laying duties notwithstanding, and the Constitution might be violated with impunity, if there were no power in the general government to correct and counteract such laws. This great object can only be safely and completely obtained by the instrumentality of the federal judiciary. ${ }^{225}$

Maclaine succinctly stated the need for finally committing the resolution of such issues to federal, rather than state, judges, noting that the problem was not the competence of state judges, but rather their dependence on and allegiance to state governments:

[Mr. Locke] supposes that the idea of cognizance of the laws of the Union to federal courts, must have arisen from suspicions of partiality and want of common integrity of our state judges. The worthy gentleman is mistaken in his construction of what I said. I did not personally reflect on the members of our state judiciary; nor did I impute the impropriety of vesting the state judiciaries with exclusive jurisdiction over the laws of the Union, and cases arising under the Constitution, to any want of probity in the judges. But if they be the judges of the local or state laws, and receive emoluments for acting in that capacity, they will be improper persons to judge the laws of the Union. A federal judge ought to be solely governed by the laws of the United States, and receive his salary from the treasury of the United States. It is impossible for any judges, receiving pay from a single state, to be impartial in cases where the local laws or interests of that state clash with the laws of the Union, or the general inter- 
ests of America. ${ }^{228}$

Marshall, too, stressed the importance of the federal courts to assuring federal supremacy, arguing, "[ $t]$ o what quarter will you look for protection from an infringement on the Constitution, if you will not give the power to the judiciary? There is no other body that can afford such a protection. ${ }^{2227}$ Responding to the concerns expressed by antifederalists that the federal courts might screen federal officers from punishments for injuries they perpetrated, Marshall suggested that "[t]here is no clause in the Constitution which bars the individual member injured from applying to the state courts to give him redress."228 This response, while constitutionally correct, ultimately proved inaccurate in light of the removal jurisdiction which Congress later afforded in such cases. $^{229}$

Randolph evidenced his continuing ambivalence over the reach of the federal judiciary, stating, "I do not concur with the honorable gentleman that the judiciary is so formidable, yet I candidly admit that there are defects in its construction, among which may be objected too great an extension of jurisdiction."230 Nevertheless, he argued that if Virginia ratified the document with the reservation "that all authority given is retained by the people, and may be resumed when perverted to their oppression; and that no right can be cancelled, abridged, or restrained, by the Congress, or any officer of the United States," there would be sufficient protections from judicial overreaching. ${ }^{231}$

Pendelton echoed the concern with enforcing federal supremacy by rejecting the idea that federal question cases could be finally relegated to the state courts, arguing, "[m]ust not the judicial powers extend to enforce the federal laws, govern its own officers, and confine them to the line of their duty? Must it not protect them, in the proper exercise

226 Id. at 172.

2273 id. at 554.

Regarding the antifederalist concern over the combination of common law, equity, and admiralty powers in one national court, see supra note 188 , Marshall failed to see "the necessity of discriminating between the three classes . . ." 3 Elliot, Debates, supra note 182, at 555 .

2283 Elliot, Debates, supra note 182 , at 554.

220 The removal jurisdiction for suits against federal officers, now codified at 28 U.S.C. $\$ \S 1442-1442 a$ (1976), evolved gradually from a series of statutes, the first of which was enacted in 1815. See Act of Feb. 4, 1815, ch. 31, § 8, 3 Stat. 195, 198-99. For a collection of the relevant statutes, see HART \& WECHSLER, supra note 3 , at 1335-38. See generally Tennessee v. Davis, 100 U.S. 257 (1880) (upholding constitutionality of statute allowing for removal from state court of civil suit or criminal prosecution against an officer of the United States); Redish \& Woods, supra note 3, at 8192.

2803 Elliot, Debates, supra note 182, at 571.

231 Id. at 576. 
of duty, against all opposition, whether from individuals or state laws?"232 Like many other federalists, Pendelton apparently doubted the ability of state judges, appointed by state governments often for fixed terms of office and sometimes dependent on state legislatures for their salaries, to enforce federal interests even when sworn and bound to do so under the commands of the supremacy clause. ${ }^{233}$

232 Id. at 548.

${ }^{283}$ See infra text accompanying notes 305-10, discussing The Federalist No. 78, in which Hamilton defends the necessity of judicial independence for the exercise of the function of judicial review. These arguments by supporters of the Constitution suggest that certain current members of the United States Supreme Court may be historically mistaken in suggesting that state judges should be assumed to be as competent and as qualified as federal judges finally to resolve federal question cases.

For example, in Stone v. Powell, 428 U.S. 465 (1976), Justice Powell said:

The policy arguments that respondents marshal in support of the view that federal habeas corpus review is necessary to effectuate the Fourth Amendment stem from a basic mistrust of the state courts as fair and competent forums for the adjudication of federal constitutional rights. The argument is that state courts cannot be trusted to effectuate Fourth Amendment values through fair application of the rule, and the oversight jurisdiction of this Court on certiorari is an inadequate safeguard. The principal rationale for this view emphasizes the broad differences in the respective institutional settings within which federal judges and state judges operate. Despite differences in institutional environment and the unsympathetic attitude to federal constitutional claims of some state judges in years past, we are unwilling to assume that there now exists a general lack of appropriate sensitivity to constitutional rights in the trial and appellate courts of the several States. State courts, like federal courts, have a constitutional obligation to safeguard personal liberties and to uphold federal law.

Id. at 493-94 n.35. Justice Powell's comments ignore the point stressed by many of the framers-the lack of complete judicial independence of many state judges due to limited terms of office, dependency on appointment or election, and, in some cases, legislative control of state judicial salaries. While these problems may be less serious today than they were in 1789 , the lack of complete judicial independence of state judges remains a problem which Justice Powell's comments misstate. Concern is not so much with the veracity or professional competency of state judges, but rather with their survivability, given their institutional setting, if they vigorously enforce the supremacy of federal law and federal constitutional rights against recalcitrant state legislators or executive officials.

One federalist supporter of the Constitution put the point quite nicely in his anonymous Letter from a Landholder, No. 5, published in the Connecticut Courant and other New England newspapers on December 3, 1787. He wrote:

State judges may be corrupt, and juries may be prejudiced and ignorant, but these instances are not common; and why shall we suppose that they will be more frequent under a national appointment and influence, when the eyes of a whole empire are watching for their detection.

Their courts are not to intermeddle with your internal policy and will have cognizance only of those subjects which are placed under the control of a national legislature. It is as necessary there should be courts of law and executive officers, to carry into effect the laws of the nation, as that there be courts and officers to execute the laws made by your state assemblies. There are many reasons why their decisions ought not to be left to 
These federalist comments defending the judicial article as necessary to enforce federal supremacy are significant because they evidence the reasons for federalist distrust of state courts in enforcing national

courts instituted by particular states.

A perfect uniformity must be observed thro the whole Union, or jealousy and unrighteousness will take place; and for a uniformity, one judiciary must pervade the whole. The inhabitants of one state will not have confidence in judges appointed by the legislature of another state, in which they have no voice. Judges who owe their appointment and support to one state will be unduly influenced and not reverence the laws of the Union. It will at any time be in the power of the smallest state, by interdicting their own judiciary, to defeat the measures, defraud the revenue, and annul the most sacred laws of the whole empire. A legislative power without a judicial and executive under their own control is in the nature of things a nullity. Congress under the old Confederation had power to ordain and resolve, but having no judicial or executive of their own, their most solemn resolves were totally disregarded.

3 Documentary History, supra note 167, at 476, 483-84; see also infra note 317 and accompanying text.

Similarly, in Cohens v. Virginia, 19 U.S. (6 Wheat.) 264 (1821), Chief Justice Marshall echoed these sentiments:

In many states, the judges are dependent for office and for salary on the will of the legislature .... When we observe the importance which that constitution attaches to the independence of judges, we are the less inclined to suppose that it can have intended to leave these constitutional questions to tribunals where this independence may not exist, in all cases where a state shall prosecute an individual who claims the protection of an act of congress .... [A] constitution is framed for ages to come ..... Its course cannot always be tranquil. It is exposed to storms and tempests, and its framers must be unwise statesmen indeed, if they have not provided it, so far as its nature will permit, with the means of self-preservation from the perils it may be destined to encounter. No government ought to be so defective in its organization, as not to contain within itself, the means of securing the execution of its own laws against other dangers than those which occur every day.

Id. at $386-87$.

Most recently, in Northern Pipeline Constr. Co. v. Marathon Pipe Line Co., 458 U.S. 50 (1982), the Supreme Court relied heavily on the necessity for judicial independence to strike down portions of the Bankruptcy Act of 1978 that committed the final determination of certain state created claims in federal bankruptcy proceedings to article I bankruptcy judges who lacked judicial independence. Speaking for four members of the Court, Justice Brennan briefly traced the history of the emphasis on judicial independence by the framers. He noted that one of the declared grievances against the king contained in the Declaration of Independence was that he had "made judges dependent on his will alone, for the tenure of their offices, and the amount and payment of their salaries." Id. at 60 (citation omitted). Brennan concluded, "[i]n sum, our Constitution unambiguously enunciates a fundamental principle-that the judicial Power of the United States' must be reposed in an independent Judiciary. It commands that the independence of the Judiciary be jealously guarded, and it provides clear institutional protections for that independence." Id. Prior to Northern Pipeline, Justice Powell was not alone in asserting the fungibility of article III and non-article III courts and judges. See, e.g., Swain v. Pressley, 430 U.S. 372 (1977); Palmore v. United States, 411 U.S. 389 (1973). Northern Pipeline may therefore mark a renaissance in the legal significance of the judicial independence that the framers so highly prized. 
law and explain why the framers sought to vest mandatorily the judicial power of the United States in the federal judiciary. While the framers had no quarrel with allowing state judges initially to decide federal questions, state judges were not trusted sufficiently, due to their dependence on and allegiance to state governments, to have what Maclaine called the "exclusive jurisdiction"2s4 over cases of federal magnitude. Since the Constitution did not require Congress to create inferior federal courts, ${ }^{295}$ the only way to assure that the state courts were not left with exclusive jurisdiction over such cases was to provide an opportunity for each and every case within the judicial power of the United States to be reviewed by the Supreme Court. Furthermore, should Congress choose to create inferior federal courts, the only way to assure that the state courts were not left with "exclusive jurisdiction" over the judicial power of the United States was to provide either for appellate review of state cases in the Supreme Court or for appeals or removal of such cases to inferior federal courts. While either course would be constitutionally permissible, one or the other avenue of federal court review was required. Thus, the federalist distrust of dependent state judges explains why the framers gave no power to Congress to adjust the powers of the national judiciary in any way other than by distributing the judicial power among various federal courts. Lack of confidence in the independence of state judges might further explain the desire of some federalists to assure that the Supreme Court had the power to review facts as well as law. ${ }^{238}$

The federalist responses to the attacks on the diversity jurisdiction were somewhat varied, although none suggested that Congress could simply curtail such authority. In the Pennsylvania convention, James Wilson, a leading figure in the drafting of article III, offered an important and detailed defense of the breadth of federal jurisdiction. He relied heavily on the view that jurisdiction over certain sensitive areas affecting international or transstate relationships must be vested in "the General Court, where the unequal and partial laws of a particular state would have had no force."2sz His defense of the national courts' jurisdiction over controversies between citizens of different states, and between a state, or citizens thereof, and foreign states, citizens, or sub-

294 See supra note 226.

235 See supra notes 56-60 \& 169 and accompanying text.

sse See supra note 206. Alexander Contee Hanson of Maryland, for example, belittled the vaunted value of the jury trial, while defending the power of the Supreme Court to review facts. He noted that jurors whose only qualifications are "property and ripe age, may more probably incur the importation of weakness, partiality, or undue influence." Ford, PAMPHLETS, supra note 21, at 238.

2372 Elliot, Debates, supra note 182 , at 495. 
jects, indicated that he not only sought a neutral forum, but also anticipated that federal courts would apply impartial national laws rather than state law in such cases: ${ }^{238}$

[I]s it not necessary, if we mean to restore either public or private credit, that foreigners, as well as ourselves, have a just and impartial tribunal to which they may resort? I would ask how a merchant must feel to have his property lie at the mercy of the laws of Rhode Island. I ask, further, How will a creditor feel who had his debts at the mercy of tender laws in other states? It is true that, under this Constitution, these particular iniquities may be restrained in future; but, sir, there are other ways of avoiding payment of debts. There have been installment acts, and other acts of a similar effect. Such things, sir, destroy the very sources of credit. 230

With similar attention to economic concerns, Pendleton of Virginia also defended the diversity jurisdiction on the ground that federal adjudication would avoid hostile anticreditor laws which delayed repayment through unanticipated installments or moratoriums or forced creditors to accept paper money or other forms of repayment worth less than the amount owed. ${ }^{240}$

Offering a lukewarm defense of diversity jurisdiction, Madison said, "I will not say it is a matter of much importance" and thought that it might safely have been left to state courts. ${ }^{241} \mathrm{He}$ argued, however, that "a strong prejudice may arise, in some states, against the citizens of others," that the administration of justice was "tardy, and even defective" in some states and therefore "[a] citizen of another state might not chance to get justice in a state court, and at all events he might think himself injured."242 Marshall also only mildly defended diversity jurisdiction, which he said might not be "absolutely necessary" but which allowed "the citizen of another state [to] obtain justice

258 See supra notes 220 \& 240 . This evidence casts considerable doubt on the constitutional dimensions of the Rules of Decision Act, ch. 20, § 34, 1 Stat. 92 (1789) (current version at 28 U.S.C. § 1652 (1976)), and Erie R.R. v. Tompkins, 304 U.S. 64 (1938). Such statements may in fact indicate that Swift v. Tyson, 41 U.S. (16 Pet.) 1 (1842), was correctly decided insofar as it suggested that the federal courts had the power and, indeed, perhaps the duty, to apply federal law to a case within their jurisdiction in the absence of a controlling federal statute, like the Rules of Decision Act, to the contrary.

sso 2 Elliot, DeBATES, supra note 182, at 491-92.

2403 id. at 549; see also 2 id. at $491-92$ (comments of James Wilson).

313 id. at 533 .

242 Id. 
without applying to our state courts."24s Indeed, he curiously suggested that diversity jurisdiction "may be necessary with respect to the laws and regulations of commerce, which Congress may make."244

Responding to fears of infringements of state sovereign immunity from the clause authorizing federal jurisdiction "in controversies between a state and citizens of another state," Madison said the objection was "without reason" since "[t]he only operation it can have, is that, if a state should wish to bring suit against a citizen, it must be brought before the federal court, "245 a construction contradicted by statements of other framers during the ratification debates. ${ }^{248}$ Marshall also defended the grant of federal court jurisdiction over suits against states. He said, "It is not rational to suppose that the sovereign power should be dragged before a court. The intent is, to enable states to recover claims of individuals residing in other states."247 By contrast, Wilson thought that the grant of such authority properly abrogated the sovereign immunity of the states in actions governed by the grant of jurisdiction.

In addition to attacking the breadth of jurisdiction committed by article III to the federal courts, antifederalists, like Grayson of Virginia, feared that the federal courts would necessarily come into conflict with the local judiciaries. ${ }^{248} \mathrm{He}$ said, "The interference of the federal judiciary and the state courts will involve the most serious and even ludicrous consequences. Both courts are to act on the same persons and things, and cannot possibly avoid interference."249 Some antifederalists, like Luther Martin, predicated much of their argument upon the assumption that the exercise of the judicial power of the United States was exclusively confined to federal courts ${ }^{250}$ and might therefore "swallow up the state jurisdiction."261 Most of the antifederalist argument was aimed at the congressional power to create inferior federal courts, an attack that was truly ironic since this congressional power was shaped in the Madisonian compromise at the Philadelphia Convention principally to respond to state autonomy concerns. ${ }^{252}$

Federalist supporters of the Constitution responded that the authority granted Congress to create inferior federal courts would not an-

243 Id. at 556.

244 Id.

245 Id. at 533.

246 See, e.g., 2 id. at $491-93$ (comments of James Wilson).

2473 id. at 555.

248 See supra note 193.

240 See id.

2Bo See supra note 189.

251 See supra note 190.

258 See supra notes 54-60 and accompanying text. 
nihilate the state courts, as the antifederalists argued. ${ }^{253}$ Pendleton argued that if the Constitution had set or confined the number of inferior federal courts, "there it would remain; nor could it be increased or diminished, as circumstances would render it necessary."254 He noted that continuing population movements westward might create the necessity of establishing federal courts for new federal territories, thereby "prov[ing] that it is better to leave them unsettled, than fixed in the Constitution."25s

Madison stressed that the jurisdiction of the federal courts was limited to a small category of cases of important national concern and therefore would not operate to destroy the state courts. He said:

in the ordinary state of things, I believe that any gentleman will think that the far greater number of causes-ninetynine out of a hundred-will remain with the state judiciaries. All controversies directly between citizen and citizen will remain with the local courts. The number of cases within the jurisdiction of these [national] courts is very small when compared to those in which the local tribunals will have cognizance. ${ }^{256}$

Marshall, too, noted the continuing jurisdiction of the state courts over the cases already within their cognizance and their concurrent jurisdiction over the controversies comprising the judicial power of the United States. He asked, "does the gentleman think that the state courts will have no cognizance of cases not mentioned here? Are there any words in this Constitution which exclude the courts of the states from those cases which they now possess?"257 Answering his own questions, he continued, "the case is so clear, that to prove it would be a useless waste of time. The state courts will not lose the jurisdiction of the causes they now decide. They have a concurrence of jurisdiction with the federal courts in those cases in which the latter have cognizance."258 In the North Carolina convention, Maclaine argued that he could not "see how the states are to be consolidated"259 by the establishment of a federal judiciary. He believed that "[ $t]$ he laws can, in general, be executed by the officers of the states. State courts and state Mason).

25s See, e.g., 3 Elliot, DeBates, supra note 182, at 521 (comments of George

286 Id. at 547 .

255 Id. at 548.

288 Id. at 537-38.

287 Id. at 553.

288 Id. at 554.

2804 id. at 139. 
officers will, for the most part, probably answer the purpose of Congress as well as any other."280 Governor Johnson of North Carolina also stated the prevailing federalist assumption that the federal courts would "have concurrent jurisdiction with the state courts, and not exclusive jurisdiction." 261 Thus, he could "see nothing in this Constitution which hinders a man from bringing suit wherever he thinks he can have justice done him."262

Pendleton of Virginia, noting the congressional power over the structure of the inferior federal courts, attempted to ameliorate antifederalist concerns by inaccurately predicting that "it [was] highly probable that their first experiment [would] be, to appoint the state courts to have the inferior federal jurisdiction, because it would be best calculated to give general satisfaction, and answer economical purposes; since a small additional salary may in that case suffice, instead of competent provision for the judges."263

The antifederalist argument regarding the expense and inconvenience of a federal judiciary was really a two-edged sword. If the national judiciary remained small and centered in the nation's capitol, it would be distant from the people and expensive and inconvenient for parties and witnesses. Such expense and inconvenience, of course, would be exacerbated if the Supreme Court's review of facts required witnesses to travel long distances to the seat of government. ${ }^{264}$ On the other hand, if the Congress chose to increase the convenience and accessibility of federal courts by establishing a sizable number of dispersed inferior courts, the expense of the federal judiciary to the taxpayers would, it was argued, outstrip its utility. Not surprisingly, few federalists addressed both prongs of the argument simultaneously, preferring instead to deal with one or the other of these arguments or finding some way out of the dilemma they created. Pendleton's idea of having Congress appoint state judges as federal judges with a small supplemental salary ${ }^{268}$ may be seen as an example of the search for a way out of this logical quagmire.

Most leading federalists viewed the fears of expense and inconvenience as exaggerated and subject to amelioration by the power of Congress to create inferior federal courts, a power curiously also opposed by the antifederalists. Some suggested that the Congress could avoid

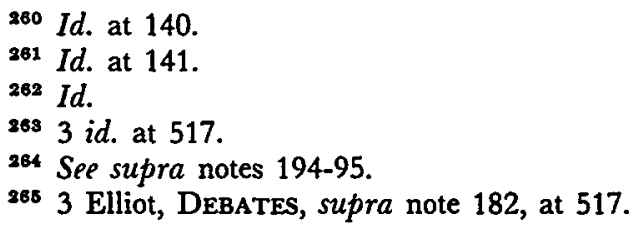


costs and inconveniences by having the Supreme Court, rather than the litigants, travel-in effect suggesting that the justices ride circuit. Madison, for example, noted the congressional power to create inferior federal courts and suggested that, as in the trials of piracies and felonies on the high seas under the Confederation, the Congress might vest the initial trial and appeals of such cases in the state courts if they are "on a good footing" without necessarily multiplying the federal courts. 206 He pointed out that while the admiralty Court of Appeals under the Confederation was "at first stationary," "it soon became a regulation that this court should be held in different parts of America, and it was held accordingly."267

The power to create inferior courts was, however, also opposed by the antifederalists. Marshall noted the inconsistency in this antifederalist position, stating:

I had an apprehension that those gentlemen who placed no confidence in Congress would object that there might be no inferior courts. I own that I thought those gentlemen would think there would be no inferior courts, as it depended on the will of Congress, but that we should be dragged to the centre of the Union. But I did not conceive that the power of increasing the number of courts could be objected to by any gentlemen, as it would remove the inconvenience of being dragged to the centre of the United States. I own that the power of creating a number of courts is, in my estimation, so far from being a defect, that it seems necessary to the perfection of this system. ${ }^{268}$

Marshall's comments reflect not only his lack of fear of expense generated by the proposed federal judicial establishment but also, possibly, an underlying assumption about the mandatory nature of federal jurisdiction. If Congress had complete control and discretion over the scope of jurisdiction of the federal courts and could leave the final resolution of any matter within the judicial power of the United States to the state courts, the power to create inferior federal courts would not have been necessary to avoid the inconvenience of being dragged to the Supreme Court in the "centre of the United States." Rather, Congress could avoid such inconvenience by leaving many or most matters to be resolved finally by the state courts. The fact that Marshall only indicates that such inconvenience can be avoided by creating inferior federal

268 Id. at 536.

267 Id.

ses Id. at 552-53. 
courts may indicate that at the time of the Virginia convention he regarded jurisdiction of the federal courts as vested and mandatory under the Constitution, notwithstanding his somewhat more expansive comments in the context of the discussion of the civil jury trial issues. ${ }^{269}$ If this reading of Marshall's views is accurate, his comment on congressional power to protect civil jury trial by excepting Supreme Court appellate review both as to law and fact may have referred only to exceptions made in favor of inferior federal courts.

It is evident from this discussion that the congressional discretion over whether to create inferior federal courts and, if created, the power over the scope of their jurisdiction was almost universally assumed and applauded by the federalists. ${ }^{270}$ This fact further demonstrates the error

268 This observation would add further weight to the view that Marshall's comments on the exceptions and regulations clause (construing that clause to allow Congress to make alterations and diminutions in the jurisdiction of the federal courts) were in fact overstated in order to respond to antifederalist critics of the judicial article. See supra notes 217-19 and accompanying text.

270 See, e.g., 3 Elliot, Debates, supra note 182, at 552-53 (comments of John Marshall); Ford, PAMPHLETS, supra note 21, at 342-44 (comments of James Iredell of North Carolina, writing as Marcus).

Alexander Contee Hanson of Maryland did, however, venture a different opinion. Writing under the pseudonym Aristides, Hanson said,

I am however fully persuaded, that, as the article speaks of an original and appellate jurisdiction, of a supreme court, and inferior courts; and, as there is no intention of appeals from the several state tribunals, the inferior federal courts are intended to have original jurisdiction in all cases, wherein the supreme court has appellate jurisdiction; and the appeal lies only from them. I can, almost, with confidence, maintain, that, as there is no express clause, or necessary implication, to oust the jurisdiction of the state courts, an action, after the adoption of the plan, may be instituted in any court, having, at this time, a jurisdiction. And if an action be brought in a state court, I do not, at present, perceive, that it can, in any manner, be transferred to the supreme or inferior federal court.

Ford, PAMPhlets, supra note 21, at 236. Hanson, who had not attended the Philadelphia Convention, but who would later serve as a delegate to the Maryland ratification convention, obviously erred in his understanding of the document. The Madisonian compromise clearly contemplated both congressional discretion over the existence and structure of inferior federal courts and also envisioned the appeal of cases originating in the state courts to the United States Supreme Court. Hanson was, however, in good company in his misconceptions, since Justice Story would later echo some of the very same arguments offered by Hanson. See supra notes 19-20. stated:

In The Federalist No. 81, at 546 (A. Hamilton) (J.Cooke ed. 1961), Hamilton

This power has been absurdly represented as intended to abolish all the county courts in the several states, which are commonly called inferior courts. But the expressions of the constitution are to constitute "tribunals INFERIOR TO THE SUPREME COURT," and the evident design of the provision is to enable the institution of local courts subordinate to the supreme, either in states or larger districts. It is ridiculous to imagine that county courts were in contemplation. 
of the arguments respectively offered by Justice Story ${ }^{271}$ and, later, Professor Goebel, ${ }^{272}$ either that jurisdiction of the inferior federal courts constitutionally must comprise the entire judicial power of the United States or, at least, that the creation of such courts was constitutionally mandated.

For the most part, the federalists rapidly disposed of or dismissed antifederalist concerns about the retroactivity of federal jurisdiction, seemingly unimpressed by these concerns. Referring to Mason's concerns about unsettling land titles to the Northern Neck of Virginia and elsewhere, Randolph dismissed the argument, saying, "I ask the Convention of the free people of Virginia if there can be honesty in rejecting the government because justice is to be done by it? . . . Are we to say that we shall discard this government because it would make us all honest?"273 Marshall noted that Mason had "acknowledged that there was no complete title" and that in light of the independence of federal judges and their sworn obligation to do justice, Mason had no reason "to apprehend partiality or injustice."274 Marshall did suggest during the debate that if the descendants of Lord Fairfax should use the federal courts the dispute would be resolved according to the laws of the state of Virginia, ${ }^{275}$ a particularly ironic statement in light of later developments in the dispute. ${ }^{278}$

Despite federalist arguments, some state conventions were sufficiently concerned about the potential breadth of federal court jurisdiction that they proposed to limit it by constitutional amendment. Many

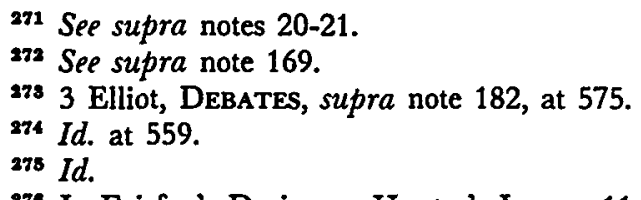

278 In Fairfax's Devisee v. Hunter's Lessee, 11 U.S. (7 Cranch) 603 (1813), the Supreme Court reversed a ruling of the Virginia Court of Appeals which had held that Lord Fairfax's lands had been validly confiscated under Virginia law prior to the Peace Treaty of 1783 and the Jay Treaty of 1794 , each of which contained guarantees against future confiscations of the property of British subjects. In reversing, the Supreme Court seemed to ignore the Virginia court's determination on the crucial issue of the time of confiscation of the Fairfax lands, apparently applying an independent federal law test to the question, since it involved the enforcement of federal treaty rights. Even then, the Court's decision seemed to ignore the language of section 25 of the Judiciary Act of 1789 which provided that "no other error shall be assigned or regarded as a grounds of reversal in any such case as aforesaid, than such as appears on the fact of the record, and immediately respects the before mentioned questions of the validity or construction of the said constitution, treaties, statutes, commissions, or authorities in dispute." Judiciary Act of 1789 , ch. $20, \S 25,1$ Stat. 86 (1789) (current version at 28 U.S.G. $\S 1257$ (1976)). This case set up the classic confrontation between the Virginia Court of Appeals and the United States Supreme Court which produced Justice Story's famous opinion in Martin v. Hunter's Lessee, 14 U.S. (1 Wheat.) 304 (1816). 
states proposed an express protection of civil jury trial, ${ }^{277}$ a proposal that culminated in the adoption of the seventh amendment by the First Congress. ${ }^{278}$ Massachusetts proposed to limit diversity jurisdiction by a jurisdictional amount, while New Hampshire's convention proposed that all diversity cases should be brought exclusively in state courts with an appeal to the Supreme Court only in common law actions where the amount in controversy was three thousand dollars or more. ${ }^{279}$ New York sought an amendment which would have limited federal jurisdiction over land controversies solely to claims of territory or jurisdiction between states and to disputes between individuals claiming under grants of different states. ${ }^{280}$ Both Rhode Island ${ }^{281}$ and Virginia ${ }^{282}$ proposed amendments to the document to prevent retroactive application of the judicial power of the United States to disputes which arose prior to the ratification of the Constitution except as to disputes between states or between individuals concerning lands claimed by or under grants from different states and suits for debts owed to the United States. Virginia proposed a revision of the breadth of the judicial power which would have limited federal court jurisdiction to cases arising under federal treaties, cases affecting ambassadors, other foreign ministers, and consuls; admiralty and maritime cases; and controversies involving the United States, or between two or more states, or between individuals claiming lands under grants from different states. ${ }^{283}$ That these states felt constitutional amendments, rather than merely statutes enacted by Congress, were necessary to limit the jurisdiction of the federal courts is, like the later adoption of the eleventh amendment, ${ }^{284}$ some evidence that the members of the state con-

277 See, e.g., 1 Elliot, DeBates, supra note 134, at 323 (proposal of Massachusetts).

276 U.S. ConST. amend. VII ("the right of trial by jury shall be preserved").

270 1 Elliot, DeBates, supra note 182 , at 323,326 . A similar proposal applicable to all cases cognizable in the federal courts was proposed by committee during the Maryland convention. $2 \mathrm{id}$. at 550.

${ }_{280} I d$. at 331 . New York also ratified with explicit understandings that federal court jurisdiction over controversies between citizens of the same state claiming lands under grants from different states was exclusively limited to the land title question, that review in common law actions was limited to writs of error which precluded review of facts, and that the jurisdiction of the federal courts could "not in any case . . . be increased, enlarged or extended, by any faction, collusion, or mere suggestion; and that no treaty is to be construed so as to operate as to alter the Constitution of any state." 1 id. at 329.

281 Id. at 336.

2823 id. at 660-61.

20s Id.

284 The eleventh amendment was ratified in 1798, after being proposed by Congress in 1794, in order to overturn the holding of Chisholm v. Georgia, 2 U.S. (2 Dall.) 419 (1793) (holding that the state of Georgia was amenable to suit brought by a citizen 
ventions did not readily assume the existence of congressional power over the scope of jurisdiction of the federal courts.

While this demand for amendment, rather than statutory enactment, may have sprung from a distrust of other states or Congress, there is a startling absence of significant suggestions that antifederalist objections to the breadth of federal court jurisdiction could be cured by congressional exceptions or regulations; the very few comments that might be found hinting at such an authority are vague and inconclusive. One somewhat inconclusive opinion to this effect was ventured by Wilson in his discussion of the power to regulate review of facts by the Supreme Court:

There are other cases in which it [regulation] will be necessary; and will not Congress better regulate them, as they rise from time to time, than could have been done by the Convention? Besides, if the regulations shall be attended with inconvenience, the Congress can alter them as soon as discovered. But any thing done in Convention, must remain unalterable but by the [amendment] power of the citizens of the United States at large.

I think these reasons will show that the powers given to the Supreme Court are not only safe, but constitute a wise and valuable part of the system. ${ }^{285}$

Tench Coxe, an influential Pennsylvanian who supported the Constitution, but who attended neither the Philadelphia Convention nor his state ratification convention, was the only federalist who ventured a less ambiguous view. He said that "the sphere of jurisdiction for the faederal courts is limited, and that sphere only is subject to the regulation of our faederal government."288 His view should be discounted somewhat, however, given the fact that his writing was informed solely by the naked text of the document unenlightened by participation in the debates at Philadelphia or any ratification convention. In arguing against adoption of the Constitution, Richard Henry Lee of Virginia, writing as "the Federal Farmer," resorted to a similar argument to

of another state in the federal courts without its consent). Nowhere in the legislative history of the amendment is there any suggestion that Congress could accomplish the same result and curtail the jurisdiction of the federal courts over such cases by mere legislative enactment. See generally C. JACORS, The EleventH AMENDMENT aNd SOVEREIGN IMMUNITY 64-74 (1972) (legislative history of the eleventh amendment following Chisholm). Apparently, Congress simply assumed that the jurisdiction of the federal courts had been vested in the national judiciary by the Constitution and could be curtailed only by constitutional amendment.

285 2 Elliot, Debates, supra note 182, at 494 (emphasis added).

28s Ford, PAMphlets, supra note 21, at 150. 
exaggerate the defects of the judicial article:

By art. 3, sect. 2, the supreme court shall have appellate jurisdiction as to law and facts with such exceptions, \& c. to what extent is it intended the exceptions shall be carried-Congress may carry them so far as to annihilate substantially the appellate jurisdiction, and the clause be rendered of very little importance. ${ }^{287}$

Phrased this boldly, it is evident why federalist supporters of the Constitution had not generally assumed or embraced the idea of congressional power over the scope of jurisdiction of the federal judicial establishment. The federalists intended to create a more powerful federal government, including a federal judiciary, with constitutionally assured powers which would be safe from encroachment from any hostile source. The power of Congress anticipated by the federalists was one of distributing judicial power, not controlling its exercise. Indeed, Noah Webster, a noted Pennsylvania attorney who vigorously supported the Constitution, nicely captured the distributive purposes of the congressional power in published remarks written within a month after adjournment of the Philadelphia Convention:

[T] ]he truth is, the creation of all inferior courts is in the power of Congress; and the constitution provides that Congress may make such exceptions from the right of appeals as they shall judge proper. When these courts are erected, their jurisdictions will be ascertained, and in small actions, Congress will doubtless direct that a sentence in a subordinate court shall, to a certain amount, be definite and final. All objection therefore to the judicial power of the federal courts appear to me as trifling as any of the preceding. ${ }^{288}$

As Noah Webster's statement suggests, the federalists generally responded to antifederalist concerns about the potentiality of the national judiciary to supersede and annihilate the state courts by suggesting that such fears were unfounded and premature, rather than by suggesting any congressional power to cure the problem by curtailing the jurisdiction of the federal courts.

One aspect of the antifederalists' expense argument-the concern over the multiplication of appeals in insignificant cases-did, however, prompt some concessions from the federalists. A case could presumably be insignificant either because a trifling amount was in controversy or 
because the issues were somehow of minimal federal concern, as, for example, where the state courts had honored federal supremacy and enforced national law, rather than conflicting state law. More often than not, the discussion of such problems during the ratification process focused on insignificance in terms of amount in controversy. ${ }^{289}$ Later, a few federalists ventured the view that Congress might limit appeals in insignificant cases by its power of making exceptions and regulations for the jurisdiction of the Supreme Court. This suggestion was inconsistent with the distributive purposes of the clause, although such comments may have been made against an unarticulated assumption that less significant cases could be relegated to the inferior federal courts-a position perfectly consistent with the original distributive purposes of the exceptions and regulations clause.

Randolph in this context again evidenced his desire further to limit and define the judicial article by suggesting that under the exceptions and regulations clause "the sum on which appeals will be allowed may be limited to a considerable amount, in order to prevent vexatious and oppressive appeals."290 Pendleton suggested that the congressional power to regulate amounts in controversy under the exceptions and regulations clause even extended to the Supreme Court's original jurisdiction. While he argued, possibly erroneously, ${ }^{201}$ that the enumeration of the Supreme Court's original jurisdiction "excludes its original jurisdiction in all other cases," he nevertheless indicated that the original jurisdiction "will not restrain Congress from regulating even these, so as to permit foreign ambassadors to sue in the inferior courts, or even to compel them to do so, where their causes may be trivial, or they have no reason to expect a partial trial."292 Later he remarked:

The appeals may be limited to a certain sum. I make no doubt it will be so. You cannot prevent appeals without great inconveniences; but Congress can prevent that dreadful oppression which would enable many men to have a trial in the federal court, which is ruinous. There is a power which may be considered as a great security. The power of making what regulations and exceptions in appeals they may think proper

289 For example, New Hampshire's convention proposed limiting appeals to the Supreme Court in common law actions to cases involving three thousand dollars or more, a considerable sum in 1787 dollars. 1 Elliot, DeBates, supra note 182, at 326. Massachusetts proposed limiting diversity jurisdiction to matters in which the dispute exceeded three thousand dollars for the Supreme Court and fifteen hundred dollars for the inferior federal courts. Id. at 323 .

2003 id. at 576.

201 See supra note 136 and accompanying text.

2823 Elliot, DeBATES, supra note 182, at 518 (emphasis added). 
may be so contrived as to render appeals, as to law and fact, proper, and perfectly inoffensive. ${ }^{293}$

Pendleton, noting the distances of some of the eastern and southern states from the nation's center, assured antifederalists that when Congress organized the Supreme Court "they will regulate it [the appellate jurisdiction] so as to exclude this danger."284 While Pendleton's comments may only suggest the limitation of appeals in insignificant cases in favor of decision by inferior federal courts-a position perfectly consistent with the original distributive purposes of the exceptions and regulations clause-some of his broader comments, like those of Randolph, might not be so limited.

\section{Some Illuminating Comments from the Sidelines}

Some of the more provocative, yet almost wholly ignored, evidence of the disposition of leading federalists to protect the powers of the judiciary from absolute control by the legislature, is found in comments made by Madison on a constitutional plan drafted by Jefferson for the proposed state of Kentucky. While these statements are not directly addressed to the national Constitution, they evidence Madison's concern with preventing the legislature from exercising unfettered control over the jurisdiction of the courts. They must be read, however, in light of the fact that they were addressed to a state court system intended to have broad plenary jurisdiction, unlike the deliberately limited jurisdiction given to the federal courts under article III. Madison wrote that "[m]uch detail ought to [be] avoided in the constitutional regulation of [the judicial] department, that there may be room for changes which may be demanded by the progressive changes in the state of our population." 295 From the context, it is apparent that Madison wanted flexibility in the structural features of the state courts so that the number of judges and courts could be altered as experience and necessity directed. He then continued: "It is at least doubtful whether ... even the boundaries of Jurisdiction ought to be made unalterable but by a revisal of the Constitution." ${ }^{298} \mathrm{He}$ explained his greater concerns about protecting jurisdiction in the following terms:

The precaution [of constitutional vesting of jurisdiction] seems no otherwise necessary than as it may prevent sudden

$203 \mathrm{Id}$. at 520.

204 Id.

29511 The Papers of James Madison 290 (A. Rutland ed. 1977).

200 Id. 
modifications of the establishment, or additions of obsequious Judges, for the purpose of evad[in]g the checks of the Constn. \& giv[in]g effect to some similar policy of the Legiere. But might not the same object be any innovations in those particulars without the annual sanction of two or three successive assemblies; over \& above the other pre-requisites to the passage of a law. ${ }^{297}$

This comment is remarkable. First, it anticipates by nearly two centuries Franklin Delano Roosevelt's court-packing plan and the proposals during the twentieth century to curtail federal court jurisdiction. ${ }^{298}$ Second, it evidences Madison's unwillingness to allow the legislature to evade the constitutional checks on its power by the simple expedient of legislatively divesting the courts of jurisdiction. Third, Madison does suggest that it might be possible to devise extraordinary structural means short of constitutional amendment to protect the jurisdictional autonomy of the judiciary while simultaneously affording the flexibility of change by legislative control. No such extraordinary structural devices, however, were built into the federal Constitution. This observation makes it unlikely that Madison, probably the single most important figure in the framing of the Constitution, would have sat quietly through both the Philadelphia Convention and the Virginia ratification convention without raising a question or objection if he believed that the Constitution vested in Congress legislative control over the scope of jurisdiction of the federal courts. While rather indirect, these comments by Madison add further weight to the observation that the framers understood article III to vest the federal judicial establishment mandatorily and constitutionally with the whole of the judicial power of the United States.

\section{The Federalist Papers: Vital Commentary from the Framers}

The Federalist Papers ${ }^{299}$ were the longest and most detailed examination of the Constitution during the ratification process. Written principally for the purpose of influencing the New York ratification process, The Federalist Papers did not, unlike most of the contemporaneous debate over ratification, confine their discourse to pointed rejoin-

297 Id.

298 See generally J. Alsop \& T. Catledge, The 168 Days (1938); J. Burns, Roosevelt: The Lion and The Fox ch. 15 (1956); G. Gunther, supra note 4, at 150-52; Leuchtenburg, The Origins of Franklin D. Roosevelt's 'Court-Packing Plan,' 1966 Sup. CT. Rev. 347.

290 The Federalist (J. Cooke ed. 1961). 
ders to antifederalist attacks on the document. Rather, The Federalist Papers ventured into lengthy and erudite discussions of political theory and structure, and coherent presentations of the meaning and interrelationship of the various sections of the Constitution. Such breadth of vision not only accounts for their length, but also explains the reason they have become an invaluable primer to American political thought, and the classic exposition on the meaning of the Constitution. ${ }^{\mathbf{3 0 0}}$

The Federalist Papers paint an organized and structured picture of the meaning of and justification for the provisions of article III. Madison, for example, evidenced his dislike for legislative encroachments on court jurisdiction. In The Federalist No. 48, he defended the importance of a degree of separation of powers, noting the invasion of liberty that had occurred in the states when the principle had been violated. ${ }^{301}$ The task of exploring and defending the judiciary provisions, however, fell principally to Alexander Hamilton of New York, who had attended the Philadelphia Convention and who would later actively support the document in the New York convention. In The Federalist No. 22 he lamented:

A circumstance, which crowns the defects of the confederation, remains yet to be mentioned-the want of a judiciary power. Laws are a dead letter without courts to expound and define their true meaning and operation. The treaties of the United States to have any force at all, must be considered as part of the law of the land. Their true import as far as respects individuals, must, like all other laws, be ascertained

${ }^{300}$ In Cohens v. Virginia, 19 U.S. (6 Wheat.) 264 (1821), Chief Justice Marshall remarked:

The opinion of the Federalist has always being [sic] considered as of great authority. It is a complete commentary on our constitution; and is appealed to by all parties, in the questions to which that instrument has given birth. Its intrinsic merit entitles it to this high rank; and the part two of its authors performed in framing the constitution, put it very much in their power to explain the views with which it was framed. These essays having being [sic] published, while the constitution was before the nation for adoption or rejection, and having been written in answer to objections founded entirely on the extent of its powers, and on its diminution of state sovereignty, are entitled to the more consideration, where they frankly avow that the power objected to is given, and defend it.

Id. at 418-19; see also Transportation Co. v. Wheeling, 99 U.S. 273, 280 (1878) ("IThe Federalist] has ever been regarded as entitled to weight in any discussion as to the true intent and meaning of the provisions of our fundamental law.").

${ }^{301}$ The Federalist No. 48, at 337 (J. Madison) (J. Cooke ed. 1961). Such violations occurred by varying judicial salaries, despite constitutional guarantees explicitly fixing them, and by the fact that "cases belonging to the judiciary department, [were] frequently drawn within legislative cognizance and determination." Id. 
by judicial determinations. To produce uniformity in these determinations, they ought to be submitted in the last resort, to one SUPREME TRIBUNAL. And this tribunal ought to be instituted under the same authority which forms the treaties themselves. These ingredients are both indispensable. If there is in each State, a court of final jurisdiction, there may be as many different final determinations on the same point, as there are courts. There are endless diversities in the opinions of men. We often see not only different courts, but the Judges of the same court differing from each other. To avoid the confusion which would unavoidably result from the contradictory decisions of a number of independent judicatories, all nations have found it necessary to establish one court paramount to the rest-possessing a general superintendance, and authorised to settle and declare in the last resort, an uniform rule of civil justice.

This is more necessary where the frame of the government is so compounded, that the laws of the whole are in danger of being contravened by the laws of the parts. In this case if the particular tribunals are invested with a right of ultimate jurisdiction, besides the contradictions to be expected from difference of opinion, there will be much to fear from the bias of local views and prejudices, and from the interference of local regulations. As often as such an interference was to happen, there would be reason to apprehend, that the provisions of the particular laws might be preferred to those of the general laws; for nothing is more natural to men in office, than to look with peculiar deference towards that authority to which they owe their official existence.

The treaties of the United States, under the present constitution, are liable to the infractions of thirteen different Legislatures, and as many different courts of final jurisdiction, acting under authority of those Legislatures . . . . Is it possible that foreign nations can either respect or confide in such a government? Is it possible that the People of America will longer consent to trust their honor, their happiness, their safety, on so precarious a foundation? ${ }^{302}$

Thus, Hamilton offered the now classic dual justifications for the establishment of a federal judiciary-assuring uniformity of federal law, and national supremacy in areas of international, national, and transstate 
concern. Significantly, while most of the federalists had emphasized the necessity of an independent federal judiciary to assure national supremacy, Hamilton was one of the few to assert the necessity of assuring uniformity of federal law. The overall lack of concern with uniformity of federal law explains why the framers at Philadelphia authorized Congress to make exceptions to the appellate jurisdiction of the Supreme Court in favor of the exercise of the judicial power by inferior federal courts. The creation of those courts would preserve the supremacy of national law in areas of international and transstate concern, while posing the possibility of divergent opinions on the meaning of that law. Thus, despite Hamilton's pleas, it appears that the framers made the preservation of national supremacy a matter of constitutional imperative, while leaving the means of assuring uniformity of federal law to congressional prerogative. ${ }^{303}$

Most of Hamilton's explanation and defense of the federal judiciary is found in his five classic essays, numbers 78 through 82 in The Federalist. ${ }^{304}$ While detailed explanation of Hamilton's arguments is unnecessary here, a brief summary of his position and some of his more important comments will further indicate the importance he placed on the need for a strong, independent national judiciary and his understanding that the judicial article not only created such an institution but constitutionally invested it with all the jurisdiction set forth in section 2 of article III.

In The Federalist Nos. 78 and 79, Hamilton focused on the need to assure judicial independence. Arguing that the judiciary was "the weakest of the three departments of power," possessing neither the powers of the legislature to control the purse nor the enforcement authority of the Executive ("the sword of the community"), Hamilton asserted "that all possible care is requisite to enable it to defend itself against their attacks."sos $\mathrm{He}$ then proceeded to argue that complete independence of the judiciary was necessary, since that department exercised the check of judicial review on the other branches of government, and "the courts of justice are to be considered as the bulwarks of a limited constitution against legislative encroachments." ${ }^{\text {"306 }}$ In the course of his explanation Hamilton made many of the same arguments to de-

sos See supra text accompanying note 134 ; see also notes $19 \& 22$ and accompanying text. But see supra note 233 (comments of "Landholder"). After rejecting some of the important historical materials, Professor Sager, nevertheless, comes to a similar conclusion by a rather nonhistorical mode of analysis. See Sager, supra note 3, at 55-57, 67-68.

so4 The Federalist Nos. 78-82, at 521-57 (A. Hamilton) (J. Cooke ed. 1961).

${ }^{305}$ Id. No. 78, at 522-23.

${ }^{306} \mathrm{Id}$. at 526. 
fend the institution of judicial review that Chief Justice Marshall would later parrot in Marbury v. Madison ${ }^{307}$ Hamilton also noted that while the people can always alter or abolish the established Constitution, "yet it is not to be inferred from this principle, that the representatives of the people, whenever a momentary inclination happens to lay hold of a majority of their constituents incompatible with the provisions in the existing constitution, would on that account be justifiable in a violation of those provisions." 308 Thus, "[u]ntil the people have by some solemn and authoritative act annulled or changed the established form, it is binding upon themselves collectively, as well as individually; and no presumption, or even knowledge of their sentiments, can warrant their representatives in a departure from it, prior to such an act." ${ }^{\text {"309 }}$ These views not only demonstrate Hamilton's recognition of the potential anti-majoritarian impacts of judicial reyiew, ${ }^{\mathbf{3 1 0}}$ they also evidence the unlikelihood that he would have quietly settled for or supported a Constitution which left the scope of federal jurisdiction to the discretion of transient legislative majorities in Congress.

In The Federalist No. 80 Hamilton defended the extent of the judicial power set forth in section 2 of article III. He argued that the judicial power would be divided into six categories of cases: (1) those that arise under federal laws, (2) those "which concern the execution of the provisions expressly contained in the articles of union," (3) those to which the United States is a party, (4) "those which involve the PEACE of the CONFEDERACY, whether they relate to the intercourse between the United States and foreign nations, or to that between the States themselves," (5) those which originate on the high seas or are of admiralty or maritime jurisdiction, and (6) "those in which the state tribunals cannot be supposed to be impartial or unbiassed."311

s07 5 U.S. (1 Cranch.) 137 (1803).

so8 The Federalist No. 78, at 527 (A. Hamilton) (J. Cooke ed. 1961).

${ }^{300}$ Id. at $527-28$.

s10 Hamilton, however, tended to dismiss the dangers inherent in judicial review.

In The Federalist he commented:

It may in the last place be observed that the supposed danger of judiciary encroachments on the legislative authority, which has been upon many occasions reiterated, is in reality a phantom. Particular misconstructions and contraventions of the will of the legislature may now and then happen; but they can never be so extensive as to amount to an inconvenience, or in any sensible degree to affect the order of the political system. This may be inferred with certainty from the general nature of the judicial power; from the objects to which it relates; from the manner in which it is exercised; from its comparative weakness, and from its total incapacity to support its usurpations by force.

Id. No. 81, at 545. See generally Clinton, supra note 11, at 711, 723-25.

s11 The Federalist No. 80, at 534 (A. Hamilton) (J. Cooke ed. 1961). 
He then separately defended the commitment of each class of cases to federal cognizance. Nowhere in his description is there any hint of legislative control over the scope of this jurisdiction, despite the fact that this would have been the logical place to discuss such powers if they had been contemplated.

In The Federalist Nos. 81 and 82, Hamilton dealt with the "partition of the judiciary authority between different courts."312 $\mathrm{He}$ noted that independence of the judicial department was better assured in the proposed Constitution, since that department was "composed of a distinct body of magistrates, instead of being one of the branches of legislature, as in the government of Great-Britain, and in that of this state [New York]." ${ }^{\text {"sis }} \mathrm{He}$ applauded such separation because, under the contrary system, "the natural propensity of such [legislative] bodies to party divisions" would create "no less reason to fear, that the pestilential breath of faction may poison the fountains of justice"314 — words not exactly favorable to legislative control of judicial powers. Indeed, he rejected the argument that an independent judiciary might encroach upon legislative authority, stating that the legislative power of impeachment (not control of judicial powers) could keep the judges from usurping the powers of other branches of government. ${ }^{315}$

It was only in connection with the distribution of powers among federal courts that Hamilton discussed any congressional control over the courts. He explained and justified the power of Congress to create inferior federal courts by stating that it "is evidently calculated to obviate the necessity of having recourse to the supreme court, in every case of federal cognizance." "316 This comment is clear evidence of Hamilton's
312 Id. No. 81, at 541 .
s13 Id. at 543 .
s14 Id, at 544 .
s1s Id. at $545-46$.
s16 Id. at 546 (emphasis added).

At the end of The Federalist No. 82, Hamilton concluded his defense of the power of the Supreme Court to review both law and fact by noting that the appellate jurisdiction of the Supreme Court to review law and fact was "subject to any exceptions and regulations which might be thought advisable; that this appellate jurisdiction does in no case abolish the trial by jury, and that an ordinary degree of prudence and integrity in the national councils will insure us solid advantages from the establishment of the proposed judiciary, without exposing us to any of the inconveniences which have been predicted from that source." Id. No. 82, at 552. Taken out of context, the first portion of this statement might be thought to suggest a broader congressional power over the scope of the jurisdiction of the federal judiciary. That construction would be inconsistent with Hamilton's other explanations of the judicial article, particularly his discussion in The Federalist No. 82. Read in context, moreover, it appears that Hamilton was making no broader claim than that Congress had the authority to protect the institution of trial by jury by curtailing the power of the Court to review facts on appeal in common law actions-a claim offered by many federalists during the ratification 
understanding of the distributive nature of the congressional power over the federal court jurisdiction. If federal court jurisdiction were subject to the complete plenary power of Congress, as dicta in some cases suggest, then there would be no "necessity" of resorting to the Supreme Court. The final decision in such cases might simply be left to state tribunals by Congress. Such a result would not, however, necessarily assure either uniformity or the supremacy of the national government in areas of international or transstate concern. That Hamilton thought there was such "necessity" indicates that he believed the federal court jurisdiction to be mandatory and the congressional power to be limited to distributing the judicial power of the United States among national courts-a result consistent with Hamilton's concern with assuring national supremacy.

Indeed, while arguing against the exclusivity of federal jurisdiction, Hamilton rejected the notion that the final resolution of cases within the judicial power of the United States should be left to state courts. He wrote:

But why, it is asked, might not the same purpose have been accomplished by the instrumentality of the state courts? This admits of different answers. Though the fitness and competency of those courts should be allowed in the utmost latitude; yet the substance of the power in question [to create inferior federal courts], may still be regarded as a necessary part of the plan, if it were only to empower the national legislature to commit to them the cognizance of causes arising out of the national constitution. To confer the power of determining such causes upon the existing courts of the several states, would perhaps be as much "to constitute tribunals," as to create new courts with the like powers. But ought not a more direct and explicit provision to have been made in favour of the state courts? There are, in my opinion, substantial reasons against such a provision: The most discerning cannot foresee how far the prevalency of a local spirit may be found to disqualify the local tribunals for the jurisdiction of national causes; whilst every man may discover that courts constituted like those of some of the states, would be improper channels of the judicial authority of the union. State judges, holding their offices during pleasure, or from year to year, will be too little independent to be relied upon for an inflexible execution of the national laws. And if

period. 
there was a necessity for confiding the original cognizance of causes arising under those laws to them, there would be a correspondent necessity for leaving the door of appeal as wide as possible. ${ }^{317}$

It would be hard to find a clearer argument justifying the reasons that the judicial power was mandatorily vested in the federal courts. ${ }^{318}$ In a like vein, Hamilton later argued:

Here another question occurs-what relation would subsist between the national and state courts in these instances of concurrent jurisdiction? I answer that an appeal would certainly lie from the latter to the supreme court of the United States. The constitution in direct terms, gives an appellate jurisdiction to the supreme court in all the enumerated cases of federal cognizance, in which it is not to have an original one; without a single expression to confine its operation to the inferior federal courts. ${ }^{319}$

327 Id. No. 81 , at $546-47$.

318 One perplexing comment was offered by Hamilton in the context of explaining that state courts would exercise concurrent jurisdiction over the categories of cases comprising the judicial power of the United States. Hamilton said:

The only thing in the proposed constitution, which wears the appearance of confining the causes of federal cognizance to the federal courts is contained in this passage-"The JUDICIAL POWER of the United States shall be vested in one supreme court, and in such inferior courts as congress shall from time to time ordain and establish." This might either be construed to signify, that the supreme and subordinate courts of the union should alone have the power of deciding those causes, to which their authority is to extend; or simply to denote that the organs of the national judiciary should be one supreme court and as many subordinate courts as congress should think proper to appoint, or in other words, that the United States should exercise the judicial power with which they are to be invested through one supreme tribunal and a certain number of inferior ones to be instituted by them. The first excludes, the last admits the concurrent jurisdiction of the state tribunals: And as the first would amount to an alienation of state power by implication, the last appears to me the most natural and the most defensible construction.

Id. No. 82, at 554 (emphasis added). Hamilton's comment that the federal courts "should exercise the judicial power with which they are to be invested" might suggest that Hamilton contemplated some future congressional action to invest the federal courts with jurisdiction. This construction of Hamilton's words, however, seems incorrect. Hamilton, rather, may have used the future tense in order to indicate that the constitutionally vested jurisdiction of the federal courts would not take effect until the ratification of the Constitution. This latter construction of Hamilton's language is supported by Hamilton's use of the future tense earlier in the paragraph to refer to "the power of deciding those causes, to which their authority is to extend" and from Hamilton's other comments discussed in this section.

s19 Id. at 555 (emphasis added). 
Similarly, Hamilton voiced the argument offered by other federalists that the exceptions and regulations clause authorized Congress to prevent Supreme Court review of facts in common law cases tried to a jury. He rejected the antifederalist assumption that Supreme Court appellate jurisdiction to review both law and fact authorized it to review facts tried to a jury, since "[t]he mode of [review] may depend on ancient custom or legislative provision, (in a new government it must depend on the latter)" and concluded that "it does not follow that the reexamination of a fact once ascertained by a jury, will be permitted in the supreme court." ${ }^{320}$ Nevertheless, he urged that any such review was subject to "such exceptions and regulations as the national legislature may prescribe" and "[t]his will enable the government to modify [Supreme Court review of facts] in such a manner as will best answer the ends of public justice and security." 321 Even then, Hamilton thought the legislative power limited: "it should [not] be thought too extensive, it might be qualified with a limitation to such causes only as are determinable at common law in that mode of trial." 322

In short, Hamilton's explanations and defense of the judiciary article in The Federalist demonstrate his understanding of the mandatory nature of the jurisdiction of the federal courts. Hamilton summed up this conclusion in an important sentence which appeared in the debates over the judiciary article: "The evident aim of the plan of the convention is that all the causes of the specified classes, shall for weighty public reasons receive their original or final determination in the courts of the union." 323

\section{The Role of the Ratification Process in Ascertaining Original Understanding}

While ascertaining the intent of a multimember body is always a perilous task due in part to the possibility of multiple, divergent views and the difficulty of explaining the votes of all members on a particular issue merely from the outcome, ${ }^{324}$ ascertaining the original intent behind any clause of the Constitution is particularly difficult. Not only must the investigation survey the debates and votes at the Philadelphia Convention, but it must also ascertain the understanding of the vast number of delegates to the state ratification conventions who supported

s20 Id. No. 81, at 550 .

291 Id. at 552 .

392 Id.

328 Id. No. 82, at 556.

sat See, e.g., Brest, The Misconceived Quest for the Original Understanding, 60 B.U.L. REV. 204, 212-17 (1980). 
the document. Where the evidence suggests a convergence of viewpoint between the drafters at Philadelphia and the delegates to the state conventions, the process is, of course, simplified. Where, however, one finds a divergence of viewpoints at these two stages, the question emerges as to which original understanding is legally significant-the original intent of the delegates at Philadelphia or the understanding of the members of the state conventions that ratified the document.

Fortunately, for most of the issues raised in this Article, this dilemma is avoided, since there seemed to be a general understanding throughout both stages that the entirety of the federal jurisdiction must be vested, as a matter of constitutional imperative, in the federal judicial establishment. In Philadelphia this understanding seemed to undergird almost all the debates over the judiciary article and was manifested in the rejection by the Committee of Detail of the Randolph proposal for limited legislative control and in the overwhelming vote on August 27 to reject congressional control. In the state conventions, it appears that the federal court's mandatory jurisdiction was widely assumed. No direct suggestion was ever offered clearly indicating that Congress could delimit the classes of controversies which could be heard in both the Supreme Court and the inferior federal courts. Rather, the debates reflected an assumption that the Constitution specified the classes of cases which the federal courts would hear, and the congressional power over jurisdiction was limited primarily to giving definition to the organization of the federal courts and distributing the judicial power of the United States among the federal judicial establishment. While the members of the state ratification conventions clearly recognized the powers of Congress to decide upon the structure of the federal judiciary by regulating the procedural mode of review of the Supreme Court and by creating inferior federal courts, this congressional power over jurisdiction appeared only to have been viewed as a corollary power to distribute, rather than delimit, the judicial power in order to fulfill the congressional authority over the shape and contours of the national courts. This view was most directly stated by Alexander Hamilton and Noah Webster, as already described. ${ }^{325}$ It was also nicely captured by Pendleton of Virginia, who in responding to antifederalist concerns about civil jury trial, urged that these concerns could be resolved under Congress's exceptions and regulations power. He noted that in construing "general words of this sort" the delegates should "give them that distributive interpretation, and liberal explication, which will not make

${ }^{\text {s2s }}$ See supra notes $288,302-23$ and accompanying text. 
them mischievous." 326 In short, neither the federalist supporters of the Constitution at the state conventions nor the drafters of the document at Philadelphia intended to subvert the powers of the federal judiciary by giving Congress authority to limit the jurisdiction of the federal judicial establishment. Those powers were mandatorily vested by the Constitution itself in the combination of the Supreme Court and whatever inferior federal courts Congress chose to create. The congressional authority over the national courts under article III and section 8 of article I was merely the power to structure the federal courts and distribute the constitutionally vested powers among the federal courts which were created.

While the framers at Philadelphia and the leading federalist figures in the ratification debates seemingly agreed upon general principles, there were, in fact, two areas of divergence concerning, first, congressional power to limit review of facts, and second, congressional power to limit resort to federal tribunals in trivial or insignificant cases. The framers at Philadelphia clearly did not intend the congressional power under the exceptions and regulations clause to modify or apply to the Supreme Court review of law and fact ${ }^{327}$ and said nothing whatsoever about congressional power to limit appeals in trivial cases. Federalist supporters of the Constitution, however, assured doubters during the ratification process that the power to limit review of fact and to limit appeals in trivial cases existed and could be used to remedy their concerns. Both of these powers could, on the one hand, be viewed merely as a corollary to the assumed congressional power to distribute federal jurisdiction among federal courts-regulating decisions of facts and judgments in trivial cases to inferior federal courts with civil juries. This interpretation is tenuous, however, since the federalist proponents of such powers did not clearly discriminate between cases appealed to the Supreme Court from the inferior federal courts and those appealed from state courts. On the other hand, if the statements are read as applicable to state court cases as well as to appeals from inferior federal courts, they provide some evidence of a limited federalist willingness to concede a modicum of congressional power over the scope of jurisdiction of the federal courts in these two limited contexts.

These statements of congressional power do not suggest the broad authority to carve a category of issues or controversies out of the constitutionally prescribed jurisdiction of the federal courts. Rather, they represent concessions of congressional power to limit the mode of review 
(i.e., review of facts) or to prevent misuse of federal judicial resources by limiting trivial, insignificant, or vexatious appeals. Such limited inroads on the constitutionally prescribed jurisdiction of the national courts could be accepted without serious damage to the independence and autonomy of the federal courts. No broader suggestion of congressional power over national court jurisdiction is consistent with the federalist fears of a subservient national judiciary dependent for its powers on congressional support. Such dependent national courts would have had difficulty serving as the check the framers intended upon legislative excesses. ${ }^{328}$ Consequently, no such suggestion emerged either in Philadelphia or during the ratification debates. Thus, the federalists' concessions of congressional power to prevent review of facts and to prevent appeals in trivial or insignificant cases must be seen, at most, as limited departures during the ratification debates from the assumed principle of federal judicial power independent of congressional control.

The important question is whether these two limited departures should be read as having engrafted two additional congressional powers onto the document not envisioned or intended by the Philadelphia framers. While the question is surely open to serious dispute, it should be answered in the affirmative. The concern over the protection of civil jury trial was the single most controversial aspect of the judiciary article. Repeated assurances by federalists that the jury trial could be protected by Congress's ability to except review of facts from Supreme Court jurisdiction in common law cases were undoubtedly a sine qua non of the approval of the article, despite the fact that the civil jury trial was later adequately protected by the adoption of the seventh amendment. ${ }^{329}$ While the concern with limiting appeals in trivial or insignificant cases was far less widespread, and the federalists' comments on the scope of congressional power in this area were somewhat ambiguous, the First Congress, when it adopted the Judiciary Act of $1789,{ }^{330}$ ignored this ambiguity and seems to have acted on the assumption that such power did in fact exist.

\section{CONCLusion}

Writing in 1814, Gouverneur Morris offered the following observations on the necessity for a history of the deliberations of the Philadelphia Convention:

2se See, e.g., supra notes 305-08 and accompanying text.

3s: U.S. CoNST. amend. VII.

sso Judiciary Act of 1789 , ch. $20, \S \S 9,11-13,25,1$ Stat. $73,76-77,78-81,85-86$ (1789) (current version codified in scattered sections of 28 U.S.G. (1976)). 
[W] hat can a history of the Constitution avail towards interpreting its provisions. This must be done by comparing the plain import of the words, with the general tenor and object of the instrument. That instrument was written by the fingers, which write this letter. Having rejected redundant and equivocal terms, I believed it to be as clear as our language would permit; excepting, nevertheless, a part of what relates to the judiciary. On that subject, conflicting opinions had been maintained with so much professional astuteness, that it became necessary to select phrases, which expressing my own notions would not alarm others, nor shock their selflove, and to the best of my recollection, this was the only part which passed without cavil. ${ }^{\mathbf{3 3 1}}$

Thus, while rejecting for other articles of the Constitution the importance of the type of historical analysis offered here, Morris recognized that the compromises that produced the provisions of the judiciary article called for more intensive historical inquiry to ascertain their meaning. Although he suggested that only "a part" of the article was written in the ambiguities of compromise, he unfortunately failed to inform us of which part. Only an intensive review of the history of the adoption of the article, such as that offered here, can unlock Morris's riddle.

In contrast, Justice Frankfurter found the language of article III to be "explicit and specific," with little of the imprecision that so characterizes the other clauses of the Constitution. ${ }^{\mathbf{3 8 2}}$ In one sense, there is a great deal to Frankfurter's portrayal of article III. The ambiguities of which Morris spoke seem not apparent in the major contours of the constitutional scheme for the judiciary, but rather emerge in the details of the plan. In its overall structure, article III reflects the precision and clarity which Frankfurter claimed to have found and upon which Gouverneur Morris prided himself. What is remarkable about the subsequent history of the development of the federal courts is that the pristine clarity of the original language and the initial understandings of the framers of the document have become so encrusted with a series of judicial and scholarly misconstructions that we hardly recall or understand that original intent. In this sense there is very little truth to Frankfurter's assertion of clarity and simplicity.

Article III begins with the ringing command that the judicial power of the United States "shall be vested in one supreme Court, and

3313 Farrand, Reconds, supra note 21, at 420 (letter to Timothy Pickering, December 22, 1814).

sas See supra text accompanying note 1 . 
in such inferior Courts as the Congress may from time to time ordain and establish." ${ }^{3 s s}$ In mandating that the entirety of the judicial power be vested in the federal judicial establishment, the framers virtually tracked the self-executing commands of articles I and II, both of which begin with a constitutional mandate providing that the legislative and executive powers of the United States "shall be vested" in Congress and the President, respectively. ${ }^{334}$ Surely, no one would suggest that in articles I and II, the words "shall be vested" only refer to some future time and permit the legislature to decide whether to commit the whole of the affected powers to these respective branches of government. When the Constitution provides that the executive powers of the United States "shall be vested" in the President, the constitutional mandate is understood as self-executing, leaving no discretion whatsoever to Congress to curtail the President's powers. ${ }^{335}$

ss3 U.S. ConsT. art. III, $\S 1$.

sst U.S. CoNST. art. I, $\S 1$ provides that "[a]ll legislative Powers herein granted shall be vested in a Congress of the United States, which shall consist of a Senate and House of Representatives." (Emphasis added.) Id. art. II, $\S 1$ provides that "[ $t$ ]he executive Power shall be vested in a President of the United States of America." (Emphasis added.)

${ }^{335}$ An illustration of the lack of congressional power over the powers exclusively vested in the President can be found in United States v. Klein, 80 U.S. (13 Wall.) 128 (1872), a case that also suggests limitations on congressional power to alter the jurisdiction of the federal courts. In 1868, President Johnson issued a general pardon to former supporters of the Confederacy. As a result, these supporters were eligible to receive compensation from the federal government, under a statute authorizing loyal citizens to recover damages for property abandoned to federal troops during the Civil War. Congress objected to this possibility and enacted legislation withdrawing jurisdiction and ordering the Court of Claims and the Supreme Court to treat the acceptance of a pardon as conclusive evidence of disloyalty. Moreover, the courts were to dismiss summarily any such case on proof of the acceptance of a pardon. The Supreme Court, in an opinion by Justice Chase, declared the statute unconstitutional, finding a twofold violation of the principle of separation of powers. First, Justice Chase said that in directing the federal courts to construe evidence in a specific fashion, contrary to its natural effect, the Congress had "inadvertently passed the limit which separates the legislative from the judicial power." Id. at 147. Second, Chase noted that the legislation infringed on the President's constitutional power to grant pardons. Id.

It might be suggested that congressional power to limit the powers of other branches stems from the necessary and proper clause of article I, section 8, clause 18 of the Constitution. Under that clause, Congress may enact all laws necessary and proper for the implementation of "all other Powers vested by this Constitution in the Government of the United States, or in any Department or Officer thereof." This power does not, however, authorize Congress to enact legislation curtailing the powers of other branches of government, particularly in those contexts where Congress shares no overlapping independent authority. $C f$. Youngstown Sheet \& Tube Co. v. Sawyer, 343 U.S. 579, 637-38 (1952) (Jackson, J., concurring) (explaining President's power to act contrary to the congressional will). Thus, the power that Congress may exercise under the necessary and proper clause over the actions of coordinate branches of government is a power to regulate, structure, and organize the implementation of the coordinate branch's authority; it is not a power to frustrate its exercise. While the line between these two forms of authority may in individual cases appear hazy, the distinction is, 
Similarly, this Article's exploration of the early history of article III demonstrates that when the members of the Philadelphia Convention drafted the judicial article, they intended to vest the power to hear all of the categories of cases comprising "the judicial Power of the United States"ss6 in a national judicial branch of government. That branch of the national government was to be composed of at least a Supreme Court, of yet indeterminate size and procedures, but not of indeterminate power, since the scope of its authority was deliberately spelled out and vested in the Court through the language of article III. Additionally, the framers at Philadelphia contemplated that Congress could create inferior federal courts to assist the national judiciary in implementing its constitutionally assigned powers. Obviously, with the power to create such courts went the power to prescribe the scope of their jurisdiction, as long as the powers of such inferior article III courts did not exceed the scope of "the judicial Power of the United States" that section 1 of article III vested in the federal judiciary. ${ }^{\mathbf{s 3 7}}$ To say that Congress was given power to determine which categories of cases would be heard by the inferior federal courts is not to say that the Congress was invested with power to determine the scope of jurisdiction of the entire federal judiciary. That jurisdiction was invested in the federal courts by the Constitution and was understood by the members of the Philadelphia Convention to be beyond curtailment by the Congress. Indeed, the Philadelphia Convention twice rejected proposals calling for the creation of such a congressional authority-in the Committee of Detail ${ }^{338}$ and in the Convention's August 27 debate over the judicial article. $^{339}$

The adoption of any proposal to give Congress power to curtail the scope of the jurisdiction exercised by the federal courts would have been unthinkable for most of the nationalist supporters of the Constitution. They were determined to insulate the federal judiciary from legislative attack by assuring the judges independence to perform their role

nevertheless, important. It prevents Congress from wholly undermining the independent authority of the coordinate branches of the federal government. The congressional power authorized under the necessary and proper clause is, thus, very much like the congressional power that this Article suggests article III and article I, section 8, clause 9 contemplated over the federal courts-a power over organization, structure, and procedures, not power over the scope of jurisdiction.

ssi U.S. ConST. art. III, §§ $1,2$.

s37 See, e.g., Yakus v. United States, 321 U.S. 414 (1944); Lockerty v. Phillips, 319 U.S. 182, 187-88 (1943); Lauf v. E.G. Shinner \& Co., 303 U.S. 323, 329-30 (1938); Sheldon v. Sill, 49 U.S. (8 How.) 441, $448-49$ (1850); Cary v. Curtis, 44 U.S. (3 How.) 236, 245 (1845). Contra the views of Justice Story discussed supra note 21 and accompanying text.

ss8 See supra notes $111-48$ and accompanying text.

sso See supra notes 158-69 and accompanying text. 
of guardians of the Constitution, at least with reference to reviewing state legislation and actions to assure conformity with the Constitution and federal law. ${ }^{940}$ The debates indicate rather vividly that the foremost concern of the framers was to adopt a plan that would assure the supremacy, rather than necessarily the uniformity, of federal law and interests. ${ }^{311}$ At the heart of that concern was a demand that all cases involving federal law questions or matters of transstate concern have an opportunity to receive at least their final determination in courts created under the authority of the national government and staffed by judges with constitutionally established guarantees of judicial independence.

While the members of the Philadelphia Convention surely contemplated the exercise of congressional powers that would affect the structure of the judiciary, the powers they granted to Congress were those of organization and implementation, not powers over the scope of federal court authority. Thus, in article III Congress was not given discretion over whether to create a federal judiciary or authority over its powers; rather, it was given power to decide whether inferior courts were necessary and, if so, to structure and organize them. The drafters of article III surely additionally contemplated that Congress would determine the size of the Supreme Court, the pay of its justices (subject, of course, to the prohibition contained in section 1 of article III, against diminishing judicial compensation), and the procedures and regulations by which the Court would exercise its authority. The framers even contemplated that Congress might, if it chose to create inferior federal courts, distribute the exercise of federal judicial authority among the inferior federal courts so as to leave the final decision on federal matters to such courts. That may have been the original intended function of the exceptions and regulations clause of article III, section 2, clause 2 (that is, if the framers did in fact intend that portion of the judicial article to constitute a single clause). ${ }^{\mathbf{3 4 2}}$ At most, then, the reference to exceptions in the so-called exceptions and regulations clause was designed to facilitate implementation of the Madisonian compromise authorizing Congress to create inferior federal courts. These congressional powers, while intimately affecting the operation of the federal courts, did not involve the scope of power or jurisdiction of the federal judiciary. In short, the original understanding of the grants of congressional authority involving the federal courts was that they included powers of implementation

s4o See generally supra notes 93-108, 305-10 and accompanying text. text.

s41 See supra notes 53-60, 153-61, 232-33, 224-26, 302-03 and accompanying

${ }^{342}$ But see supra notes 140-41 and accompanying text. 
and distribution of judicial authority, similar to the grant of legislative authority under the necessary and proper clause to implement the powers granted to the legislative and executive branches of government. ${ }^{343}$

Like the evidence from the Convention, the evidence from the ratification debates negates the existence of any broad congressional powers over the scope of the jurisdiction committed to the federal judiciary. The antifederalists generally took the position that article III of the Constitution was self-executing and mandatory. In this way they could justify their attacks on the breadth of authority committed to the federal judiciary. ${ }^{\text {344 }}$ Although in the Virginia ratification convention debates a few comments to the contrary were made by John Marshall, ${ }^{345}$ whose subsequent judicial comments may form the origins of the myth of congressional power to curtail the jurisdiction of the federal judiciary, ${ }^{\text {s46 }}$ and by Randolph who had refused to sign the Constitution due to the structure of article III, most of the federalists seemingly agreed with the antifederalists that the jurisdiction of the federal courts was vested in the federal judiciary by the Constitution and not subject to legislative manipulation. There were, however, two limited types of congressional authority that the federalist supporters of the Constitution were willing to concede during the ratification debates: the power to set jurisdictional amount limitations to avoid burdensome and vexatious cases or appeals involving small sums that would force litigants to distant federal courts, and the power to limit the Supreme Court's appellate powers to review facts in order to preserve the common law institution of the jury trial. Since these concessions were needed to ratify the Constitution, they probably should be viewed as having been constructively engrafted onto the document, although nowhere expressly contemplated by the framers during the Philadelphia Convention.

While the observation that article III does not grant any broad congressional authority over federal jurisdiction is not historically startling and, indeed, was offered rather early in our history by Alexander Hamilton $^{\text {347 }}$ and, in part, by Justice Story and Gouverneur Morris, ${ }^{348}$ it is nevertheless today a remarkable rediscovery in light of the current historical and legal view of article III. Relying in great part on the fact

s4s See supra note 335 .

344 See supra notes 201-02 and accompanying text; see also supra text accompanying notes $187-88$.

sis See supra notes 217-19 and accompanying text; see also supra notes 212-16 and accompanying text (comments of Randolph).

346 See infra notes 353-54 and accompanying text.

s47 See supra notes $19,312-23$ and accompanying text.

s4 See supra notes 20-21 and accompanying text. 
that the Judiciary Act of $1789^{349}$ purportedly did not invest the whole of "the judicial Power of the United States" in the federal courts, many argue that such was never the original intent of the framers. ${ }^{350}$ Similarly, while early decisions of the Supreme Court occasionally debated the legal question of congressional authority over the scope of the federal judicial power, ${ }^{351}$ the subsequent position taken by the Court sub-

s49 1 Stat. 73 (1789) (current version codified in scattered sections of 28 U.S.C. (1976)).

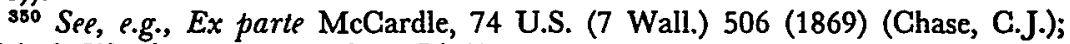
Redish \& Woods, supra note 3, at 56-61.

s51 As a Justice of the Supreme Court, James Wilson offered the view that the appellate jurisdiction of the Supreme Court was vested in that Court by the Constitution and was not subject to diminishment by Congress. In Wiscart v. D'Auchy, 3 U.S. (3 Dall.) 321 (1796), Wilson wrote in dissent:

For my part, I concur in the opinion, that, notwithstanding the provisions of the judicial act, an appeal is the natural and proper mode of removing an admiralty cause, and, in that case, there can be no doubt, that all the testimony which was produced in the court below, should also be produced in this court. Such an appeal its expressly sanctioned by the constitution; it may, therefore, clearly in the first view of the subject, be considered as the most regular process; and as there are not any words in the judicial act restricting the power of proceeding by appeal, it must be regarded as still permitted and approved. Even, indeed, if a positive restriction existed by law, it would, in my judgment, be superseded by the superior authority of the constitutional provision.

Id. at 325 (emphasis added). Since Wilson sat on the Committee of Detail that was instrumental, as we have seen, in formulating the judicial article, his views on the question of the constitutional authority of the Congress to restrict the appellate jurisdiction of the Supreme Court cannot be lightly dismissed. It should also be noted that Wilson's concern with presenting the full factual record to the Supreme Court for review is consistent with the position that he took during the Convention, defending the power of the Supreme Court to review facts in appeals cases. See supra notes 162-64 and accompanying text.

Wilson's comments in Wiscart did not go unanswered, however. Justice Oliver Ellsworth, who drafted and led the adoption of the Judiciary Act of 1789 , responded by stating, "[t]he question, therefore, on the constitutional point of an appellate jurisdiction, is simply, whether Congress has established any rule for regulating its exercise?" Wiscart, 3 U.S. (3 Doll.) at 327. While Ellsworth had attended the Philadelphia Convention, he was not a member of the Committee of Detail, and he left the convention prior to the debate of August 27, 1789, during which many of the crucial issues relating to the judicial article, including the issue of legislative control over the jurisdiction of the federal courts, were debated and resolved.

Additionally, Justice Story ventured the view in Martin v. Hunter's Lessee, 14 U.S. (1 Wheat.) 304 (1816), that

[t] ]he judicial power must, therefore, be vested in some court, by congress; and to suppose that it was not an obligation binding on them, but might, at their pleasure, be omitted or declined, is to suppose, that, under the sanction of the constitution, they might defeat the constitution itself; a construction which would lead to such a result cannot be sound.

Id. at 329.

In Ex parte Crane, 30 U.S. (5 Pet.) 190, 202 (1831), Justice Baldwin said in dissent that "the courts of the United States are capable of exercising the whole judicial power as conferred by the constitution; and though congress are bound to provide by 
stantially rejected the idea that article III invested the federal judiciary with mandatory jurisdiction subject to neither congressional alteration nor curtailment. ${ }^{362}$ The Court's current doctrinal assumptions rest primarily on the uninformed views of Chief Justice Marshall, ${ }^{\text {s5s }}$ who has

law for its exercise, in all cases to which that judicial power extends; yet it has not been done . ...." (emphasis added). Baldwin conceded, however, possibly as a result of the influence of Chief Justice Marshall, that an act of Congress was necessary to give effect to the jurisdiction contemplated in article III and that in default of such enactment, the federal courts were powerless, albeit possibly unconstitutionally so.

At least with respect to the appellate jurisdiction of the Supreme Court, Justice Johnson's early comments indicate that he believed that the powers of the Court were derived from article III and not subject to legislative diminishment. In United States v. Hudson and Goodwin, 11 U.S. (7 Granch) 32 (1812), he wrote:

The powers of the general Government are made up of concessions from the several states-whatever is not expressly given to the former, the latter expressly reserve. The judicial power of the United States is a constituent part of those concessions-that power is to be exercised by Courts organized for the purpose, and brought into existence by an effort of the legislative power of the Union. Of all the Courts which the United States may, under their general powers, constitute, one only, the Supreme Court, possesses jurisdiction derived immediately from the constitution, and of which the legislative power cannot deprive it. All other Courts created by the general Government possess no jurisdiction but what is given them by the power that creates them, and can be vested with none but what the power ceded to the general Government will authorize them to confer.

Id. at 33 (emphasis added).

ss2 See Cary v. Curtis, 44 U.S. (3 How.) 236, 245 (1845); Barry v. Mercein, 46 U.S. (5 How.) 103, 120-21 (1847); United States v. Curry, 47 U.S. (6 How.) 106, 113 (1848); Sheldon v. Sill, 49 U.S. (8 How.) 441, $448-49$ (1850); In re Kaine, 55 U.S. (14 How.) 103, 120 (1852); Daniels v. Chicago \& R.I. R.R., 70 U.S. (3 Wall.) 250, 254 (1865); Merchants Ins. Co. v. Ritchie, 72 U.S. (5 Wall.) 541, 543 (1866); City of Nashville v. Cooper, 73 U.S. (6 Wall.) 247 (1867); Ex parte McCardle, 74 U.S. (7 Wall.) 506 (1869); Ex parte Yerger, 75 U.S. (8 Wall.) 85, 98-99 (1869); Murdock v. City of Memphis, 87 U.S. (20 Wall.) 590, 620 (1874); The "Francis Wright," 105 U.S. 381, 386 (1881); St. Louis \& I.M. Ry. v. Taylor, 210 U.S. 281, 292 (1908); see also supra notes 337, 350; infra note 304. But see Glidden Co. v. Zdanok, 370 U.S. 530, 605 n.11 (1962) (Douglas, J., dissenting) (suggesting that "[t]here is a serious question whether the McCardle case could command a majority view today").

sss Chief Justice Marshall's classic judicial statement of his position is contained

in Durousseau v. United States, 10 U.S. (6 Cranch) 307 (1810):

It is contended, that the words of the constitution vest an appellate jurisdiction in this court, which extends to every case not excepted by congress; and that if the court had been created, without any express definition or limitation of its powers, a full and complete appellate jurisdiction would have vested in it, which must have been exercised in all cases whatever. The force of this argument is perceived and admitted. Had the judicial act created the supreme court, without defining or limiting its jurisdiction, it must have been considered as possessing all the jurisdiction which the constitution assigns to it. The legislature would have exercised the power it possessed of creating a supreme court, as ordained by the constitution; and in omitting to exercise the right of excepting from its constitutional powers, would have necessarily left those powers undiminished.

The appellate powers of this court are not given by the judicial act. They are given by the constitution. But they are limited and regulated by 
neither attended the Convention nor, so far as we can tell, seen

the judicial act, and by such other acts as have been passed on the subject. When the first legislature of the Union proceeded to carry the third article of the constitution into effect, they must be understood as intending to execute the power they possessed of making exceptions to the appellate jurisdiction of the supreme court. They have not, indeed, made these exceptions in express terms. They have not declared, that the appellate power of the court shall not extend to certain cases; but they have described affirmatively its jurisdiction, and this affirmative description has been understood to imply a negative on the exercise of such appellate power as is not comprehended within it.

Id. at 313-14. Marshall's argument actually appears to represent a synthesis of two opposing positions, those of Wilson and Ellsworth. See supra note 351. Like Wilson, Marshall advanced the view that the powers of the Supreme Court were invested in a self-executing manner in the Court by virtue of article III. Thus, the powers of the Court do not technically derive from the Judiciary Act of 1789; rather, they are given by the Constitution. Wilson thought that such powers were not subject to congressional diminishment, since they represented constitutional imperatives. Marshall, however, advanced the view that Congress would invoke the exceptions and regulations clause to diminish the constitutionally prescribed appellate jurisdiction of the Court. This position obviously aligned Marshall with Ellsworth's view that Congress held the complete power over the jurisdiction of the federal courts, including the Supreme Court. In placing such broad reliance on the exceptions and regulations clause, Marshall misstated the historical intention of the framers. Moreover, he merely echoed an argument he had previously made during the Virginia ratification convention that even then was not embraced by other federalist supporters of the document. See supra notes 217-19 and accompanying text. It might be speculated that Marshall's position in Durousseau was dictated by his prior statements during the Virginia ratification convention. In this sense Marshall, as a jurist, may have been a captive of his own prior political statements made during the ratification debates. Finally, it must be recalled that Marshall's comments, even when made, were relatively aberrational insofar as they indicated the existence of congressional power to curtail the appellate jurisdiction of the Supreme Court over issues of law within the judicial power of the United States.

Durousseau is an important decision because Chief Justice Chase later relied upon it in Ex parte McCardle, 74 U.S. (7 Wall.) 506 (1869). Durousseau was not, however, Marshall's only pronouncement on the subject of congressional authority over the jurisdiction of the federal courts. In fact, the Durousseau opinion was probably presaged by Marshall's opinion in United States v. More, 7 U.S. (3 Cranch) 159 (1805).There Marshall wrote:

[W] hen the constitution has given congress power to limit the exercise of our jurisdiction, and to make regulations respecting its exercise; and congress under that power, has proceeded to erect inferior courts, and has said in what cases a writ of error or appeal shall lie, an exception of all other cases is implied. And this court is as much bound by an implied as an express exception.

This argument would be unanswerable, if the supreme court had been created by law, without describing its jurisdiction. The constitution would then have been the only standard by which its powers could be tested, since there would be clearly no congressional regulation or exception on the subject. But as the jurisdiction of the court has been described, it has been regulated by congress, and an affirmative description of its powers must be understood as a regulation, under the constitution, prohibiting the exercise of other powers than those described.

Id. at 171-73. 
Madison's notes of the debates. ${ }^{354}$

Insofar as the current doctrinal assumptions about the constitutional scope of the power of the federal courts derive from the allegedly limited jurisdiction granted to the national judiciary under the Judiciary Act of 1789, ${ }^{385}$ such arguments may be misguided. While detailed consideration of these arguments is beyond the scope of this piece, such arguments grossly oversimplify the post- 1789 history of the implementation of the judicial article.

There is considerable evidence that nationalist supporters of the Judiciary Act of 1789 were confronted with the same antifederalist sentiments that animated the debate over the adoption of the Constitution and were forced to refight the same battles that they had won during the Philadelphia Convention and the ratification debates, ${ }^{356}$ sometimes with somewhat different results. Thus, it may be that the Judiciary Act of 1789 should be viewed more as a continuation of a pre-existing political debate than as a principled and conscientious effort on the part of

244 Madison's notes were not published until 1840. 1 Farrand, REcoRDS, supra note 21, at xv. While the Journal of the Convention was first published in 1819 by order of Congress, the Journal was sufficiently sketchy that it provided little information from which to attempt to ascertain the original understanding of constitutional clauses, and it was hardly used for that purpose by the courts during this period. Id. at xi-xiv. The Journal contained neither references to debates during the Convention nor to the deliberations of various important committees. The only Virginian known to have attended the Philadelphia Convention and kept any notes was Marshall's political enemy in the ratification struggle, George Mason. It is rather doubtful that Marshall would have received notes from that source. Furthermore, the actual deliberations of the Convention on the judicial article were not referred to by Marshall or anyone else during the Virginia ratification convention, further suggesting the unavailability of that material.

ass The primary limitations on the exercise of federal court jurisdiction contained in the Judiciary Act of 1789 were jurisdictional amount limitations, prohibitions on review of fact, limitations on Supreme Court review of state law questions in cases decided by state courts unless they were plainly related to the resolution of the federal question posed by the case, and limitations on Supreme Court review of state court decisions sustaining a federal constitutional, statutory, or treaty claim against contrary state law. Judiciary Act of 1789 , ch. $20, \S \S 9,11-13,25,1$ Stat. 73, 76-77, 78-81, 8586 (1789) (current version codified in scattered sections of 28 U.S.C. (1976)).

ase In this classic article on the history of the Judiciary Act of 1789, Professor W.arren said:

[T] he final form of the Act and its subsequent history cannot be properly understood, unless it is realized that it was a compromise measure, so framed as to secure the votes of those who, while willing to see the experiment of a Federal Constitution tried, were insistent that the Federal Courts should be given the minimum powers and jurisdiction. Its provisions completely satisfied no one, though they pleased the Anti-Federalists more than the Federalists.

Warren, New Light on the History of the Federal Judiciary Act of 1789, 37 HaRv. L. REv. 49, 53 (1923) (footnote omitted). See generally J. GoEbel, supra note 3, at 457508. 
Congress to implement the constitutional plan prescribed in article III. In any event, it is reasonably clear that the federalist supporters of the Judiciary Act believed that Congress had a duty to effectuate the mandates of article III and had no discretion to decide whether to invest the federal courts with the entirety of the judicial power of the United States. For example, in the House of Representatives, William Smith of South Carolina, a federalist supporter of the Judiciary Act, said the following during debate on the bill:

There is another important consideration; that is, how far the constitution stands in the way of this motion [to limit the federal courts to entertaining admiralty and maritime cases]. It is declared by that instrument that the judicial power of the United States shall be vested in one supreme, and in such inferior courts as Congress shall from time to time establish. Here is no discretion, then, in Congress to vest the judicial power of the United States in any other tribunal than in the Supreme Court and the inferior courts of the United States. . . . What is the object of the motion? To assign the [final] jurisdiction of some of these very cases to the State courts, to judges, who, in many instances, hold their places for a limited period; whereas, the constitution, for the greater security of the citizen, and to insure the independence of the federal judges, has expressly declared that they shall hold their commissions during good behaviour. To judges who are exposed every year to a diminution of salary by the State Legislatures; whereas, the constitution, to remove from the federal judges all dependence on the Legislative or Executive, has protected them from any diminution in their compensation. Whether the expediency or the unconstitutionality of the motion be considered, there are more than sufficient reasons to oppose it. ${ }^{\mathbf{3 5 7}}$

Indeed, since the primary limitations, often by way of omission, contained in the Judiciary Act of 1789 on the exercise by any federal court of the judicial power of the United States relate to jurisdictional amount limitations, appellate review of facts, and appellate review of federal question cases decided by state courts involving federal claims that were sustained by the state tribunals (i.e., cases involving a trivial federal supremacy interest), ${ }^{958}$ the federalist supporters of the Judiciary

2s7 1 Annals of Congress 831-32 (J. Gales ed. 1789).

ss8 See supra note 355. 
Act of 1789 may well have believed that they had granted to the federal courts the whole of the judicial power of the United States, at least the whole of that power as it was understood during the ratification process. $^{\text {s68 }}$

Thus, it appears that the notion of congressional power over the scope of jurisdiction of the federal courts was decidedly not part of the initial constitutional plan. Instead it emerged gradually in contravention to the original understanding of the framers through the judicial construction, or misconstruction, of the language of the instrument. ${ }^{\mathbf{3 6 0}}$

s30 Recall, that in the ratification debates the federalists conceded that Congress had authority to banish trivial matters from federal court dockets and to protect the right to jury trial by curtailing the power of the Supreme Court to review fact as well as law. See generally supra text accompanying notes 327-30. It may well be that the supporters of the Judiciary Act of 1789 understood the jurisdictional amount limitations and the lack of federal review of state court decisions sustaining a federal claim against contrary state law as examples of the exercise of authority to keep unnecessary, trivial cases, i.e., those in which there is no serious matter of national or transstate concern, out of the federal courts. Similarly, the curtailment of Supreme Court authority to review fact as well as law was also expressly contemplated during the ratification debates and, therefore, marked no new departure in the adoption in the Judiciary Act of 1789. Thus, the Judiciary Act of 1789 may be reconciled with the idea that the jurisdiction of the federal courts is vested in the national judiciary by the Constitution and is not subject to congressional diminishment except in these two limited classes of cases discussed during the ratification debates. Such an explanation would surely help clarify how Representative Smith and other federalist supporters of the bill could simultaneously argue that the antifederalists had no power to curtail the authority of the federal courts prescribed by the Constitution, while supporting a judiciary bill that seemingly did not grant to the federal courts all of the potential jurisdiction contained in "the judicial Power of the United States" prescribed by section 2 of article III.

380 After some initial disputes within the Court over the meaning of article III, see supra note 351, Chief Justice Marshall's initially aberrant position gained currency on the Court. See supra note 353. Thus, by the time the Court decided Ex parte McCardle, 74 U.S. (7 Wall.) 506 (1869), Chief Justice Chase could cite Marshall's opinions and say:

[T] he principle that the affirmation of appellate jurisdiction implies the negation of all such jurisdiction not affirmed having been thus established [in Durousseau], it was an almost necessary consequence that acts of Congress, providing for the exercise of jurisdiction, should come to be spoken of as acts granting jurisdiction, and not as acts making exceptions to the constitutional grant of it.

Id. at 513.

None of the major early cases explored the historical information discussed in this Article, since most of the data were then unpublished and unavailable. Even after the publication of Madison's notes in 1840, subsequent cases like McCardle relied on judicial precedent, rather than original historical research, to explicate the meaning of article III. Significantly, most of the early cases almost uniformly ignored the imperative language of section 1 of article III commanding that the "judicial Power of the United States shall be vested" in the federal courts. In the only case that seriously considered this language, Martin v. Hunter's Lessee, 14 U.S. (1 Wheat.) 304 (1816), Justice Story arrived at a conclusion precisely opposite to that offered in McCardle, finding the language of article III to be mandatory. See supra notes 10-11.

Possibly, the best example of the Court's lack of attention to language and detail is 
The modern significance of this observation is a subject beyond the purview of this Article. The historical conclusions of this piece, however, should have important implications for the manner in which a number of important modern federal jurisdiction questions are resolved, at least if the "original understanding" is to have any role in our approach to interpreting the judicial article, notwithstanding the existence of contrary precedent. ${ }^{361}$

While at least one eminent legal scholar has written that efforts to suggest that Congress lacks complete power over the scope of jurisdiction of the federal courts might be dismissed as "absurd" or "may reflect wishful thinking," contrary conclusion. Even those who argue for significant limitations on congressional power over the judiciary generally have conceded the existence of congressional power to curtail the jurisdiction of the Supreme Court. These scholars and jurists rely principally on important constitutional policy considerations, rather than history, to support their con-

the failure of Chief Justice Chase to include the important comma in his quotation of the exceptions and regulations clause in McCardle, a bit of punctuation of potentially powerful significance. See supra notes $140-45$ and accompanying text.

s61 In the area of constitutional interpretation, the doctrine of stare decisis surely plays an important role. Cf., e.g., Northern Pipeline Constr. Co. v. Marathon Pipe Line Co., 458 U.S. 50, 93 (1982) (White, J., dissenting). Contra Burnet v. Coronado Oil \& Gas Co., 285 U.S. 393, 406-07 (1932) (Brandeis, J., dissenting) ("But in cases involving the Federal Constitution, where correction through legislative action is practically impossible, this Court has often overruled its earlier decisions."). See generally Monaghan, Taking Supreme Court Decisions Seriously, 39 MD. L. REv. 1 (1979). The decisions on the scope of congressional power over federal court jurisdiction are based on shaky precedent. Most of the cases trace their doctrinal origins to the early decisions of the Court authored by Chief Justice Marshall. See supra notes 351-54. For example, in the classic case of Ex parte McCardle, 74 U.S. (7 Wall.) 506, 513 (1869), the Court relied significantly on Chief Justice Marshall's dicta in Durousseau v. United States, 10 U.S. (6 Cranch.) 307 (1810), to suggest that the jurisdiction of the Supreme Court, while technically granted by article III of the Constitution, may be limited and regulated by acts of Congress under the so-called exceptions and regulations clause. Chief Justice Marshall did not have available to him Madison's notes or the other journals detailing the history of the Philadelphia Convention. In this context, where the existing judicial precedents are based substantially on inadequate or inaccurate data and assumptions, prior precedent arguably should play a diminished role in the process of constitutional interpretation.

On the other hand, immediate adoption by the federal courts of the original understanding of article III offered in this Article might cause serious dislocation in the existing judicial structure and raise difficult questions about certain existing jurisdictional statutes. See, e.g., 28 U.S.C. \$§ 1341-42 (1976). Thus, the perspectives offered in this Article may be more relevant to judicial review of future jurisdictional curtailment statutes, whether addressing issues like abortion or school prayer or classes of jurisdiction like proposals to abolish diversity of citizenship jurisdiction. The interpretations offered here would also be pertinent to efforts to extend the existing precedents affording broad congressional discretion over the jurisdiction of the federal courts.

${ }_{862}$ Currie, The Constitution in the Supreme Court: 1789-1801, 48 U. CHI. L. REv. 819, 848 (1981). 
clusions. $^{383}$ Perhaps the best example of such an approach was the plea of former Justice Roberts in 1949 for the adoption of a constitutional amendment protecting against congressional curtailment of the appellate jurisdiction of the Supreme Court to entertain cases arising under the Constitution and to review both law and fact. ${ }^{364}$ Roberts, who had witnessed the debate over President Franklin Roosevelt's Court-packing plan from the perspective of the Supreme Court bench, argued that such an amendment was a necessary "core of the Court's fulfilling its independent functions in our system of government." Ex parte McCardle ${ }^{\mathbf{3 6 \theta}}$ and the decisions of Chief Justice Marshall, Roberts conceded the existence of extensive congressional power over the jurisdiction of the Supreme Court, even to the point of "taking away, bit by bit, all the appellate jurisdiction of the Supreme Court of the United States." 367 He attempted to explain this seeming inconsistency on the part of the framers as follows:

Why did [the framers] then leave it to Congress to regulate the appellate jurisdiction of the Court? I think they did not envisage any such large federal judiciary as we have to-

ses See, e.g., HART \& WEChSLER, supra note 3, at 1364-65; Ratner, Power, supra note 3, at 161; Redish \& Woods, supra note 3, at 52-75; Sager, supra note 3, at 30-36. The question of the existence of congressional power to curtail federal court jurisdiction is important not only to scholars interested in study of federal jurisdiction, but also to those who debate the legitimacy of noninterpretive judicial review. Among the checks on the federal judiciary usually offered by the defenders of broad judicial powers is the assumed congressional authority to curtail federal court jurisdiction. See, e.g., J. Choper, Judictal Review of the National Process: A Functional Reconsideration of the Role of the Supreme Court 52-55 (1980); M. Perry, The Constitution, The Courts, and Human Rights 125-39 (1982). Indeed, Professor Perry seems to rely almost exclusively on the existence of the congressional power to curtail federal court jurisdiction to resolve the tensions he perceives between majoritarian theory and noninterpretive judicial review. Yet, when it comes to defending the existence of the congressional power, Perry offers little justification. At one point he states, "no one denies the existence of national legislative power over the jurisdiction of the federal judiciary, including the appellate jurisdiction of the Supreme Court." Id. at 130. Yet elsewhere he admits a personal reluctance to concede to Congress the power to curtail federal court jurisdiction and invites "attempts to avoid a concession to Congress of a broad jurisdiction-limiting power." Id. at 138. Perry, however, never clearly indicates whether the success of such attempts would require a total reevaluation of his theory of the legitimacy of noninterpretive judicial review. The conclusions of this Article may represent the beginnings of the theory that Perry invited. At a minimum, they surely belie Perry's suggestion that "no one" denies the existence of congressional jurisdictional curtailment powers. These conclusions are, however, arrived at through an interpretivist approach, thereby suggesting that Perry might feel freer to dismiss or criticize them.

sot Roberts, Now is the Time: Fortifying the Supreme Court's Independence, 35

A.B.A. J. 1 (1949).

${ }^{\text {ses }}$ Id. at 4.

36874 U.S. (7 Wall.) 506 (1869).

807 Id. 
day. The federal judiciary was rather in the background-that is, the lower judiciary. The theory was that constitutional questions would arise in state courts and then an appeal would come to the Supreme Court from a decision of a state court on a constitutional question. ${ }^{368}$

This Article indicates that Roberts and others have paid insufficient attention to the overall language, structure, and history of article III. Rather than ignoring lower federal courts, as Roberts suggests, the federalist supporters of the Constitution fought hard for their creation, seeking first to establish the lower courts by constitutional mandate and, after that was unsuccessful, granting constitutional authorization for Congress to create them. Similarly, the framers did not leave the appellate jurisdiction of the Supreme Court to congressional whim, but rather, invested it in the Supreme Court and specifically spelled out its content. The reason in both instances was to assure that cases within the judicial power of the United States received at least the opportunity for a final resolution by an independent, presumably neutral, federal tribunal. On this point the federalists were adamant, mandating the existence of such jurisdiction in article III. Thus, the arguments, like those offered by Justice Roberts or Professors Hart, Ratner, and Sager, for safeguarding the jurisdiction of the federal courts from congressional curtailment are not only sound as a matter of constitutional policy, they are also well grounded in the history of the origins of article III. It is, indeed, a remarkable reflection on how far modern judicial doctrine has departed from the original intention of the framers that Justice Roberts should propose a constitutional amendment to accomplish precisely what the Philadelphia Convention originally intended. ${ }^{368}$

The quote from Justice Frankfurter that began this Article is indicative of a career dedicated to seeking simplicity and clarity in the exercise of federal court jurisdiction. Frankfurter saw article III as a relatively simple and precise instrument that only needed appropriate implementation..$^{370}$ Unfortunately, he viewed article III through the

${ }^{368} I d$. at 3.

360 The historical conclusions of this Article obviously suggest certain avenues of response to recurrent congressional proposals to curtail the jurisdiction of the federal courts. For examples of congressional proposals to curtail federal jurisdiction, see supra notes 3-10. Additionally, the conclusions of this Article may raise serious questions about the constitutionality of congressional efforts completely to dispense with diversity of citizenship jurisdiction.

s70 See supra note 1. See generally F. Frankfurter \& H. Shulman, Cases and Other Authorities on Federal Jurisdiction and Procedure (1937); F. Frankfurter \& W. Katz, Gases and Other Authorities on Federal Juris- 
cloud of misinterpretation contained in the scholarship and decisions that had preceded him. Ironically, the original understanding of the framers who drafted and ratified article III was very simple. It involved investing the federal courts with the whole of a described set of powers called the "judicial Powers of the United States," and allowing Congress merely to work out the structures and procedure by which those powers would be exercised and to distribute the constitutionally defined powers among the various federal courts it structured. The scope of the federal judicial power was neither left in doubt nor committed to congressional discretion. The extent of federal jurisdiction was precisely spelled out in article III and nowhere left to congressional curtailment. Article III was, indeed, clear and precise; it meant exactly what it said-a point Justice Frankfurter made, but misunderstood. ${ }^{371}$

diction and Procedure (1931); F. Frankfurter \& J. Landis, The Business of THE Supreme Court: A Study in the Federal Judicial System (1928).

371 See, e.g., National Mut. Ins. Co. v. Tidewater Transfer Co., 337 Ụ.S. 582, 655 (1949) (Frankfurter, J., dissenting) ("Congress need not give this Court any appellate power; it may withdraw appellate jurisdiction once conferred and it may do so even while a case is sub judice. Ex parte McCardle . . . .). 


\author{
APPENDIX \\ Proposals, Plans, and Drafts of the \\ Judicial Article Considered at \\ or Prepared for the \\ Constitutional Convention*
}

A. Randolph's Virginia Plan [1 Farrand, RECoRDs, supra note 21, at 21-22]

9. Resd. that a National Judiciary be established to consist of one or more supreme tribunals, and of inferior tribunals to be chosen by the National Legislature, to hold their offices during good behaviour; and to receive punctually at stated times fixed compensation for their services, in which no increase or diminution shall be made so as to affect the persons actually in office at the time of such increase or diminution. That the jurisdiction of the inferior tribunals shall be to hear $\&$ determine in the first instance, and of the supreme tribunal to hear and determine in the dernier resort, all piracies $\&$ felonies on the high seas, captures from an enemy; cases in which foreigners or citizens of other States applying to such jurisdictions may be interested, or which respect the collection of the National revenue; impeachments of any National officers, and questions which may involve the national peace and harmony.

B. Paterson's New Jersey Plan [1 Farrand, ReCoRDs, supra note 21, at 244]

5. Resd. that a federal Judiciary be established to consist of a supreme Tribunal the Judges of which to be appointed by the Executive, \& to hold their offices during good behaviour, to receive punctually at stated times a fixed compensation for their services in which no increase or diminution shall be made, so as to affect the persons actually in office at the time of such increase or diminution; that the Judiciary so estab-

* This appendix reflects the major drafts of the judiciary article as they are set forth in full in 1-4 Farrand, ReCoRDs, supra note 21. Many changes were made during the debates over the judicial article at the Philadelphia Convention that are not reflected "in these drafts, since the changes were not reported as part of a complete draft or plan. These drafts are, however, set forth as major guideposts that are essential to understanding the significance of those debates. 
lished shall have authority to hear \& determine in the first instance on all impeachments of federal officers, \& by way of appeal in the dernier resort in all cases touching the rights of Ambassadors, in all cases captures from an enemy, in all cases of piracies \& felonies on the high seas, in all cases in which foreigners may be interested, in the construction of any treaty or treaties, or which may arise on any of the Acts for regulation of trade, or the collection of the federal Revenue: that none of the Judiciary shall during the time they remain in Office be capable of receiving or holding any other office or appointment during their time of service, or for thereafter.

C. Pinckney Plan (outline) [2 Farrand, Records, supra note 21, at 136]

15. S. \& H.D. in G. ass. shall institute Offices and appoint Officers for the Departments of for. Affairs, War, Treasury and Admiralty -

They shall have the exclusive Power of declaring what shall be Treason \& Misp. of Treason agt. U.S.-and of instituting a federal judicial Court, to which an Appeal shall be allowed from the judicial Courts of the several States in all Causes wherein Questions shall arise on the Construction of Treaties made by U.S.- - or on the Law of Nations-or on the Regulations of U.S. concerning Trade \& Revenue-or wherein U.S. shall be a Party-The Court shall consist of Judges to be appointed during good Behaviour-S. \& H.D. in C. ass shall have the exclusive Right of instituting in each State a Court of Admiralty, and appointing the Judges \&c of the same for all maritime Causes which may arise therein respectively.

D. Hamilton Plan [3 Farrand, RECoRDs, supra note 21, at 625-27]

\section{Article V}

§I. There shall be a chief. Justice of the Supreme Court, who together with the other Judges thereof, shall hold their offices during good behaviour, removeable only by conviction on impeachment for some crime or misdemeanor-Each Judge shall have a competent Salary to be paid to him at stated times, and not to be diminished during his continuance 
in office.

The Supreme Court shall have original jurisdiction in all causes in which the United States shall be a party, in all controversies between the United States, and a particular State, or between two or more States, except such as relate to a claim of territory between the United States, and one or more States, which shall be determined in the mode prescribed in the VI article; in all cases affecting foreign Ministers, Consuls and Agents; and an appellate jurisdiction both as to law and fact in all cases which shall concern the Citizens of foreign nations, in all questions between the Citizens of different States, and in all others in which the fundamental rights of this Constitution are involved, subject to such exceptions as are herein contained and to such regulations as the Legislature shall provide.

The Judges of all Courts which may be constituted by the Legislature shall also hold their places during good behaviour, removeable only by conviction on impeachment for some crime or misdemeanor, and shall have competent salaries to be paid at stated times and not to be diminished dur: ing their continuance in office; but nothing herein contained shall be construed to prevent the Legislature from abolishing such Courts themselves.

All crimes, except upon impeachment, shall be tried by a Jury of twelve men; and if they shall have been committed within any State, shall be tried within such State; and all civil causes arising under this Constitution of the like kind with those which have been heretofore triable by Jury in the respective States, shall in like manner be tried by jury; unless in special cases the Legislature shall think proper to make different provision, to which provision the concurrence of two thirds of both Houses shall be necessary.

$\S$ Impeachments of the President and and Vice President of the U- States, members of the Senate, the Governours and Presidents of the several States, the principal or chief Officers of the Departments enumerated in the $10 \S$. of the 4th. Article, Ambassadors and other like public Ministers, the Judges of the Supreme Court, Generals and Admirals of the Navy shall be tried by a Court to consist of the Judges of the Supreme Court, and the Chief Justice or first senior Judge of the superior Court of law in each State, of whom twelve shall constitute a Court. A majority of the 
Judges present may convict. All other persons shall be tried on impeachment by a court to consist of the Judges of the supreme Court and six Senators drawn by lot, a majority of whom may convict.

Impeachments shall clearly specify the particular offence for which the party accused is to be tried, and judgment on conviction upon the trial thereof shall be either removal from office singly, or removal from office and disqualification for holding any future Office or place of trust; but no Judgment on impeachment shall prevent prosecution and punishment in the ordinary course of law; provided that no Judge concerned in such conviction shall sit as Judge on the second trial. The Legislature may remove the disabilities incurred by conviction on impeachment.

\section{Article VI}

Controversies about the rights of territory between the United States and particular States shall be determined by a Court to be constituted in manner following. The State or States claiming in opposition to the United States as parties shall nominate a number of persons, equal to double the number of Judges of the Supreme Court for the time being, of whom none shall be citizens by birth of the States which are parties, nor inhabitants thereof when nominated, and of whom not more than two shall have their actual residence in one State. Out of the persons so nominated the Senate shall elect one half, who together with the Judges of the supreme Court, shall form the Court. Two thirds of the whole number may hear and determine the controversy, by plurality of voices. The States concerned may at their option claim a decision by the Supreme Court only. All the members of the Court hereby instituted, shall, prior to the hearing of the Cause take an Oath impartially, and according to the best of their judgments and consciences, to hear and determine the controversy.

E. Sherman's Proposals** [3 Farrand, ReCoRds, supra note 21, at 616]

To make laws binding on the people of the United

**Serious doubt exists whether the document containing Sherman's proposals was prepared for the Constitutional Convention or, rather, was prepared later in Sherman's life in order to propose amendments to the Constitution. 3 Farrand, RECoRDS, supra 
States, and on the courts of law, and other magistrates and officers, civil and military, within the several states, in all cases which concern the common interests of the United States: but not to interfere with the government of the individual states, in matters of internal police which respect the government of such states only, and wherein the general welfare of the United States is not affected.

That the laws of the United States ought, as far as may be consistent with the common interests of the Union, to be carried into execution by the judiciary and executive officers of the respective states, wherein the execution thereof is required.

That the legislature of the United States be authorised to institute one supreme tribunal, and such other tribunals as they may judge necessary for the purpose aforesaid, and ascertain their respective powers and jurisdictions.

F. Draft of Randolph Proposals as They Emerged from the Deliberations of the Committee of the Whole, June 13, 1787 [1 Farrand RECORDS, supra note 21, at 230-31]

11 Resolved. that a national Judiciary be established to consist of

\section{One supreme Tribunal}

The Judges of which to be appointed by the second Branch of the National Legislature.

to hold their offices during good behaviour

to receive, punctually, at stated times, a fixed compensation for their services: in which no encrease or diminution shall be made so as to affect the persons actually in office at the time of such encrease or diminution

12 Resolved. That the national Legislature be empowered to appoint

$$
\text { inferior Tribunals. }
$$

13 Resolved. that the jurisdiction of the national Judiciary shall extend to cases which respect the collection of the national revenue: impeachments of any national Officers: and questions which involve the national peace

note 21 , at 615 . It is clear, however, that the Sherman proposals never made an appearance at the Philadelphia Convention and did not influence the course of its deliberations. The document has not, accordingly, been given any serious consideration in this Article. 
and harmony.

G. Randolph-Rutledge Draft in Committee of Detail [2 Farrand, RECORDS, supra note 21, at 146-47]

5. The Judiciary

1. shall consist of one supreme tribunal

2. the judges whereof shall be appointed by the senate

3. and of such inferior tribunals, as the legislature may (appoint) <establish>

(4. the judges of which shall be also appointed by the senate-)

5. all the judges shall hold their offices during good behaviour;

6. and shall receive punctually,

at stated times a (fixed) compensation for

their services, to be settled by the legislature

in which no diminution shall be made, so as to affect the persons actually in office at the time of such diminution.

and shall swear fidelity to the union. extend

7. The jurisdiction of the supreme tribunal shall

I to all cases, arising under laws passed by the general <Legislature>

2. to impeachments of officers, and

3. to such other cases, as the national legislature may assign, as involving the national peace and harmony,

in collection of the revenue in disputes between citizens of different states

$<$ in disputes between a State \& a Citizen or Citizens of another State>

in disputes between different states; and

in disputes, in which subjects or citizens of other countries are concerned

$<\&$ in Cases of Admirality Jurisdn $>$

But this supreme jurisdiction shall be appellate only, except in <Cases of Impeachment. \& (in) > those instances, in which the legislature shall make it original. and the legis- 
lature shall organize it

8. The whole or a part of the jurisdiction aforesaid according to the discretion of the legislature may be assigned to the inferior tribunals, as original tribunals.

\section{H. Wilson-Rutledge Draft in Committee of Detail 2 Farrand,} RECORDS, supra note 21, at 172-73]

The Judicial Power of the United States shall be vested in one Supreme (National) Court, and in such (other) <inferior $>$ Courts as shall, from Time to Time, be constituted by the Legislature of the United States.

The Judges of the Supreme (National) Court shall (be chosen by the Senate by Ballott). (They shall) hold their Offices during good Behaviour. They shall, at stated Times, receive for their Services, a Compensation, which shall not be diminished during their Continuance in Office.

The Jurisdiction of the Supreme (National) Court shall extend to all Cases arising under Laws passed by the Legislature of the United States; to all Cases affecting Ambassadors (and other) <other $>$ public Ministers $<\&$ Consuls $>$, to the Trial of Impeachments of Officers of the United States; to all Cases of Admiralty and Maritime Jurisdiction; to Controversies between <States,-except those wh. regard Jurisdn or Territory,-betwn $>$ a State and a Citizen or Citizens of another State, between Citizens of different States and between $<a$ State or the $>$ Citizens (of any of the States) <thereof $>$ and foreign States, Citizens or Subjects. In Cases of Impeachment, (those) <Cases> affecting Ambassadors (and) other public Ministers $<\&$ Consuls $>$, and those in which a State shall be (one of the) $<a>$ Part(ies) $\langle y\rangle$, this Jurisdiction shall be original. In all the other Cases beforementioned, it shall be appellate, with such Exceptions and under such Regulations as the Legislature shall make. The Legislature may (distribute) <assign any part of $>$ th(is)e Jurisdiction <above mentd.,-except the Trial of the Executive - $>$, in the Manner and under the Limitations which it shall think proper (among) $<$ to $>$ such (other) <inferior > Courts as it shall constitute from Time to Time.

(Crimes shall be tried $\langle \&\rangle$ in the State, (in which) $<$ where $>$ they shall be committed; (and) The Trial of 
(them) < all Criml Offences,-except in Cases of Impeachment $->$ shall be by Jury.

$<$ Judgmts. in Gases of Impeachmt. shall not extend further than to removal from Office \& disqualifn. to hold \& enjoy any place of Honr. Trust or Profit under the U.S. But the party convicted shall nevertheless be liable \& subject to Judl. Trial Judt \& Punishment according to (the) Law of (the Land) $>$

I. Report of the Committee of Detail [2 Farrand, RECoRDs, supra note 21 , at 186-87]

$$
\mathrm{XI}[\mathrm{X}]
$$

Sect. 1. The Judicial Power of the United States shall be vested in one Supreme Court, and in such inferior Courts as shall, when necessary, from time to time, be constituted by the Legislature of the United States.

Sect. 2. The Judges of the Supreme Court, and of the Inferior Courts, shall hold their offices during good behaviour. They shall, at stated times, receive for their services, a compensation, which shall not be diminished during their continuance in office.

Sect. 3. The Jurisdiction of the Supreme Court shall extend to all cases arising under laws passed by the Legislature of the United States; to all cases affecting Ambassadors, other Public Ministers and Consuls; to the trial of impeachments of Officers of the United States; to all cases of Admirality and maritime jurisdiction; to controversies between two or more States, (except such as shall regard Territory or Jurisdiction) between a State and Citizens of another State, between Citizens of different States, and between a State or the Citizens thereof and foreign States, citizens or subjects. In cases of impeachment, cases affecting Ambassadors, other Public Ministers and Consuls, and those in which a State shall be party, this jurisdiction shall be original. In all the other cases before mentioned, it shall be appellate, with such exceptions and under such regulations as the Legislature shall make. The Legislature may assign any part of the jurisdiction above mentioned (except the trial of the President of the United States) in the manner, and under the limitations which it shall think proper, to such Inferior Courts, as it shall constitute from time to time.

Sect. 4. The trial of all criminal offences (except in 
cases of impeachments) shall be in the State where they shall be committed; and shall be by Jury.

Sect. 5. Judgment, in cases of Impeachment, shall not extend further than to removal from Office, and disqualification to hold and enjoy any office of honour, trust or profit, under the United States. But the party convicted shall, nevertheless be liable and subject to indictment, trial, judgment and punishment according to law.

\section{J. Draft Referred to the Committee of Style [2 Farrand, RECoRDs,} supra note 21 , at 575-76]

\section{$\mathrm{XI}$.}

Sect. 1. The Judicial Power of the United States both in law and equity shall be vested in one Supreme Court, and in such Inferior Courts as shall, when necessary, from time to time, be constituted by the Legislature of the United States.

Sect. 2. The Judges of the Supreme Court, and of the Inferior courts, shall hold their offices during good behaviour. They shall, at stated times, receive for their services, a compensation, which shall not be diminished during their continuance in office.

Sect. 3. The Judicial Power shall extend to all cases both in law and equity arising under this Constitution and the laws of the United States, and treaties made or which shall be made under their authority; to all cases affecting Ambassadors, other Public Ministers and Consuls; to all cases of Admiralty and Maritime Jurisdiction; to Controversies to which the United States shall be a party, to controversies between two or more States (except such as shall regard Territory and Jurisdiction) between a State and citizens of another State, between citizens of different States, between citizens of the same State claiming lands under grants of different States, and between a State or the citizens thereof and foreign States, citizens or subjects. In cases affecting Ambassadors, other Public Ministers and Consuls, and those in which a State shall be party, the Supreme Court shall have original jurisdiction. In all other cases beforementioned the Supreme Court shall have appellate jurisdiction both as to law and fact with such exceptions and under such regulations as the Legislature shall make.

Sect. 4. The trial of all crimes (except in cases of im- 
peachments) shall be by jury and such trial shall be held in the State where the said crimes shall have been committed; but when not committed within any State then the trial shall be at such place or places as the Legislature may direct.

The privilege of the writ of Habeas Corpus shall not be suspended; unless where in cases of rebellion or invasion of public safety may require it.

Sect. 5. Judgment, in cases of Impeachment, shall not extend further than to removal office, and disqualification to hold and enjoy any office of honour, trust or profit under the United States. But the Party convicted shall nevertheless, be liable and subject to indictment, trial, judgment and punishment, according to law.

\section{J. Draft Reported Out by the Committee of Style $[2$ Farrand,} RECORDS, supra note 21, at 600-01]

Sect. I. The judicial power of the United States, both in law and equity, shall be vested in one supreme court, and in such inferior courts as the Congress may from time to time ordain and establish. The judges, both of the supreme and inferior courts, shall hold their offices during good behaviour, and shall, at stated times, receive for their services, a compensation, which shall not be diminished during their continuance in office.

Sect. 2. The judicial power shall extend to all cases, both in law and equity, arising under this constitution, the laws of the United States, and treaties made, or which shall be made, under their authority. To all cases affecting ambassadoŕs, other public ministers and consuls. To all cases of admiralty and maritime jurisdiction. To controversies to which the United States shall be a party. To controversies between two or more States; between a state and citizens of another state; between citizens of different States; between citizens of the same state claiming lands under grants of different States, and between a state, or the citizens thereof, and foreign States, citizens or subjects.

In cases affecting ambassadors, other public ministers and consuls, and those in which a state shall be a party, the supreme court shall have original jurisdiction. In all the other cases before mentioned, the supreme court shall have appellate jurisdiction, both as to law and fact, with such exceptions, and under such regulations as the Congress shall 
make.

The trial of all crimes, except in cases of impeachment, shall be by jury; and such trial shall be held in the state where the said crimes shall have been committed; but when not committed within any state, the trial shall be at such place or places as the Congress may by law have directed.

Sect. 3. Treason against the United States, shall consist only in levying war against them, or in adhering to their enemies, giving them aid and comfort. No person shall be convicted of treason unless on the testimony of two witnesses to the same overt act, or on confession in open court.

The Congress shall have power to declare the punishment of treason, but no attainder of treason shall work corruption of blood nor forfeiture, except during the life of the person attainted. 